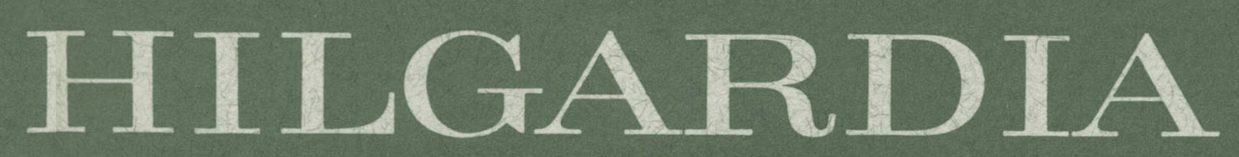

A JOURNAL OF AGRICULTURAL SCIENCE PUBLISHED BY THE CALIFORNIA AGRICULTURAL EXPER IMENT STATION

Volume 34, Number $10 \cdot J u l y, 1963$

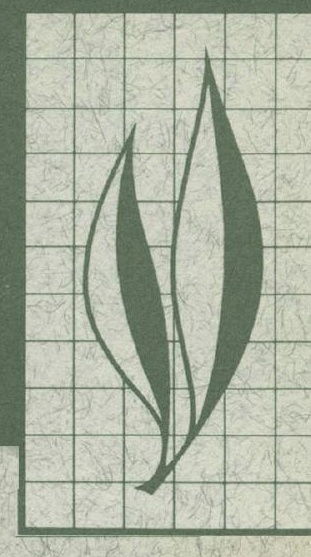

\title{
Regional Location of Cattle Feeding - A Spatial Equilibrium Analysis
}

\author{
G. A. King and L. F. Schrader
}




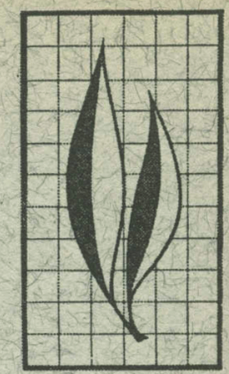

This study focuses on factors affecting the regional location of cattle feeding. Briefly stated, these factors include the regional demand for beef, transfer costs for carcass beef and for the intermediate products of feeds and feeder cattle, feed conversion efficiency by region, and regional supplies of the intermediate products of concentrate feed, hay, and feeder cattle. The study is a partial equilibrium approach to the location of feedlots, taking as given the location of production of other livestock products.

A competitive equilibrium model was developed for analyzing the location of cattle feeding for a 20-region breakdown of the United States for the 1957-58 feeding year. A linear programming technique was utilized to quantify the model. The solution generated provides the spatial distribution of cattle feeding by region, the pattern of interregional shipments of intermediate products and of carcass beef, a set of equilibrium prices for beef, and imputed prices for intermediate products by region.

Four models were quantified to test alternative model specifications as to feedlot nonfeed costs, regional feed conversion efficiency, and regional demand for beef. Results indicate no simple rules for location of cattle feeding, but rather stress the importance of considering the interrelationships among the major variables such as the regional demand for beef, regional intermediate product supply, regional feed conversion efficiency, and transfer costs for the intermediate products and for carcass beef.

\section{THE AUTHORS:}

G. A. King is Associate Professor of Agricultural Economies, and Associate Economist in the Agricultural Experiment Station and on the Giannini Foundation, Davis. L. F. Schrader was formerly Assistant Specialist in the Agricultural Experiment Station, and is now Research Economist, Lever Brothers Company, New York. 


\section{Regional Location of Cattle Feeding-A Spatial Equilibrium Analysis ${ }^{1}$}

\section{INTRODUCTION}

THE LOCATION of feedlots in various regions of the country depends on a set of interdependent relationships in the feed-livestock economy. In the aggregate, these relationships involve regional demand for livestock products, production functions for livestock products and intermediate goods such as feeds and feeder cattle, regional availability of factors of production, and transfer cost functions for both products and intermediate products which tie regions together in a spatial equilibrium sense. An analysis of one segment of the livestock complex, such as cattle feeding, requires simplifying assumptions as to other related segments of the feed-livestock economy.

Approximately one-half of the beef supply in the United States is obtained from cattle that are feedlot finished. Other sources include cull dairy animals, cull beef animals, grass-fattened cattle, and imported meat. The basic functions of the feedlot finishing are the conversion of feedstuffs into meat and improvement in the grade of the meat. Feedlot finishing also tends to even out the supply of cattle moving from producing areas to meet the seasonal demand for meat. This may be ac- complished by varying the length of the feeding period and the associated concentrate-roughage ratio in the ration. The feedlot finishing of beef cattle may be considered as a production activity requiring three major variable inputs: feeder cattle, feed concentrates, and hay or other roughages. Feedlot operations vary from farm feeding of cattle, mainly on home-grown feeds, to large commercial feedlots with all major inputs shipped into the area.

Feedlot operators compete with producers of other livestock and poultry producers for feed supplies. With given regional demands for livestock products, the regional production of the various products depends on the region's competitive advantage in livestock and other agricultural products. Although a complex interrelated system is recognized for the optimum location of all livestock production, the present study is a partial equilibrium approach to the location of feedlots, taking as "given" the location of production of other livestock products.

This study ${ }^{2}$ is concerned primarily with the development and application of a spatial equilibrium model to determine the "optimum" location of feed-

\footnotetext{
${ }^{1}$ Submitted for publication November 9, 1962.

${ }^{2}$ This study reports, in part, research undertaken under Western Regional Research Project WM-37, Economics of Transportation of Livestock and Meats in the Western Region, under authority of the Agricultural Marketing Act of 1946. The initial model of this study was presented in a dissertation "A Spatial Equilibrium Analysis of Cattle Feeding in the United States," submitted by L. F. Schrader to the Graduate Division, University of California, May 1961, and an abbreviated statement of methodology and results were reported by Schrader and King (1962). Other aspects of the problem are based on subsequent analyses by the senior author.
} 
lots under specified conditions as to feeder cattle location, feed supplies, nonfeed costs of feedlot operations, and feed conversion efficiency by region, given regional demand and transfer cost functions. The specific objectives are: (1) to present a framework for the analysis of interregional competition for the case where (a) both intermediate products, such as feed and feeders, and product may be shipped among regions and (b) where alternative production activities are specified for conversion of intermediate products into the final product; (2) to apply the model to the analysis of the location of cattle feeding operations in the United States; (3) to determine the effect on location of modifying assumptions of the model as to nonfeed costs and feeding efficiency; (4) and to appraise the possible effect of other factors such as economies of scale in feedlot operations on location. This analysis should contribute to the basic methodology that can be applied in studies of interregional competition, especially for those types of production activities which require consideration of shipments of both raw materials and products. It also provides the quantification of the effect of factors influencing location of feedlot facilities. Although more refined data are required for feed conversion efficiency by region, demand functions by region, and other input data, the study should be of methodological value to the industry in planning location of facilities for the production and processing of beef, an item that will be of increased relative importance in the average U.S. diet of an economy with rising levels of income and with changing food consumption preferences.

\section{FRAMEWORK OF ANALYSIS}

\section{THEORETICAL CONSIDERATIONS}

The basic determinants of location of economic activity include regional endowment of natural resources, production functions for intermediate and final products, transfer cost functions, and the demand functions for the products. Theoretically, a spatial equilibrium solution to the location of production can be derived with given regional levels of resource and factor availability, technology, transfer costs, and demand. Also derived are the associated flows of products and intermediate products among regions consistent with equilibrium prices for the final products. The theoretical basis for a spatial general equilibrium model was developed by Lefeber $(1958)^{3}$ and presented in a programming framework. This model incorporates into neoclassical production analysis the assumption of discrete location points and equilibrium conditions for the transportation inputs required for shipment of intermediate and final products among regions. It builds on the previous work of location theorists and other economists concerned with general equilibrium theory and with the introduction of spatial aspects into economic analysis. The development by Lefeber has proved particularly helpful in specifying the present model which is, however, a partial equilibrium analysis.

Location theorists have broadened the pioneering analysis of Thunen (1930 ed.) in his study of the effect of transportation on the composition of agricultural production in a uniformly fertile plain surrounding a single market. He emphasized the competition among various types of agricultural products and their relative ability to pay land rent, thus determining the pattern of land use. In contrast, Weber (1909) placed major emphasis on the location of the individual firm and (Lefeber, 1958, p. 3) "is credited with being the first to attempt the analysis of the choice of industrial location in terms of trans-

\footnotetext{
${ }^{3}$ See "Literature Cited," pages 415-16.
} 
port costs, wages, and raw material prices. His analytical approach, however, did not yield an adequate economic theory; and it was E. M. Hoover (1937) who combined the relevant Weberian analysis with the contemporary notions embodied in the theory of the firm and partial equilibrium analysis." Other important contributions have been made to the theory of location of agricultural production by Dunn (1944) in broadening the Thunen approach and by Losch (1944) and Isard (1956) in moving toward an integration of Walrasian general equilibrium theory which ignored location aspects and location theory.

In addition to the contributions made by location theorists, Lefeber (1958, p. 6) notes the developments due to "those neoclassical economists who gave their attention to the problem of introducing transportation into economic analysis." The contributions of Samuelson (1952), Baumol (1952), and Koopmans and Beckmann (1957) are important in development of spatial equilibrium analysis, especially in stating such problems in a programming formulation. This theoretical approach has proved to be of considerable value in applied research. The point-trading models, such as developed by Samuelson for a single product partial equilibrium model, assume a given fixed number of discrete location points rather than the continuous plane of location sites common to the development of location theorists such as Hoover, for example. However, a model of discrete location points would provide a solution approaching that obtained from a model assuming a continuous plane of location sites as the number of points is increased."

The partial equilibrium analysis for a single product as developed by Samuelson (1952) provides the basic framework for the present model, although refinements are introduced to allow for shipment of intermediate goods and for specification of alternative production activities rather than introduction of a supply curve for the product as such. The single-product case will be outlined briefly to provide a point of departure for discussion of the modification introduced.

The spatial equilibrium model for a single product involves the following problem (Samuelson, 1952). We are given at each of two or more locations a demand and supply curve for a product and the transportation costs for shipping the product between any pair of regions. What will be the equilibrium level of prices in all markets, the amount supplied and demanded at each location, and the quantity shipped between regions? Equilibrium conditions are illustrated in figure 1 for the two-region case. In region 1 , the supply curve is indicated as $S_{1}$ and in region 2 as $S_{2}$. Given demand relationships $D_{1}$ and $D_{2}$, and with no trade between the two regions, the equilibrium price in region 1 is $P_{1}$ and in region 2 is $P_{2}$. These are points where the supply and demand curves in each market just meet, or where the

"As Isard (1956, pp. 168-169) points out: "If excess supply functions could be derived for each infinitesimally small area of the world and if the Samuelson-Beckman formulation could be considered relevant and adequate and could yield a quantitative solution, then the location problem would be solved. Corresponding to each infinitesimally small area, there would be a unique scale of output (zero or positive amount of production) such as Enke obtains for each region in his more limited model. We would then have our geographic distribution of production. Theoretically, both the location and transportation patterns would be derived simultaneously.

"In practice, however, the Samuelson-Beckmann formulation ignores a number of basic locational forces, as Beckmann fully recognizes, and more important is not now able, and is not likely in the future to be able to yield a quantitative solution for every infinitesimally small area. It is at this juncture that location theory makes its contribution. For location theory seeks principles to narrow down, and greatly narrow down the number of points to be considered as potential locations for the production of any given commodity. Once a relatively small number of production points or regions are isolated, the Enke-Samuelson-Beckmann formulation may offer a more efficient approach to the determination of the resulting geographic flows of commodities." 


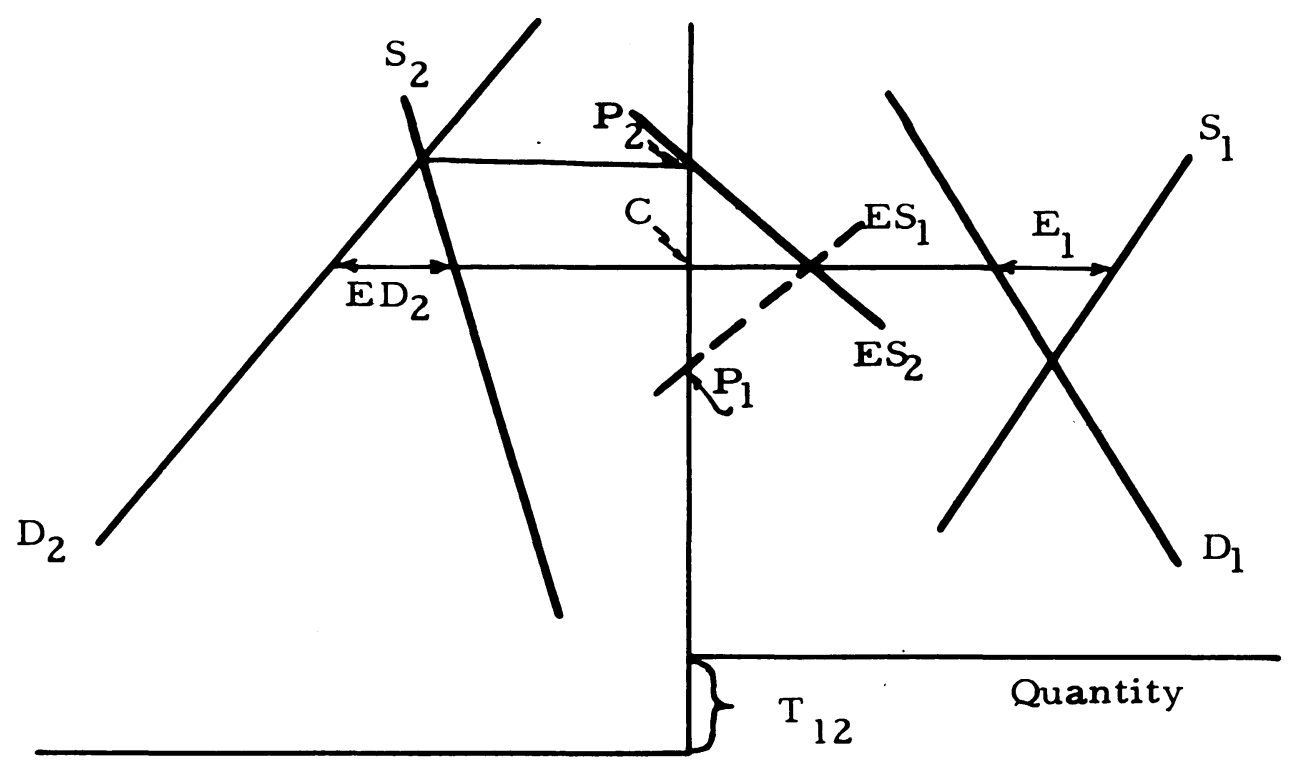

Quantity

Region $2 \quad$ Region 1

Fig. 1. Hypothetical two-region model illustrating the determination of equilibrium market prices and shipment pattern with given supply and demand curves.

excess-supply functions $E S_{1}$ and $E S_{2}$ which equal the demand curve subtracted laterally at every price from the supply curve-are at their respective zero values.

The product can be shipped from region 1 to 2 for $T_{12}$ dollars per ton, and from region 2 to 1 for $T_{21}$ dollars per ton. Since the pre-trade price is lower in region 1 than in 2 , trade flows only from 1 to 2 and $T_{12}$ is the relevant transportation cost. Since the initial difference in prices exceeds the transportation cost, shipments are made from region 1 to 2 ; and at equilibrium, $P_{2}$ exceeds $P_{1}$ by the amount of $T_{12}$. For this reason, the axes of region 1 are displaced relative to those of region 2 by the distance representing $T_{12}$. The new equilibrium price under interregional trade flows is established at $O C$ where the excess-supply function of region $1\left(E S_{1}\right)$ intersects the excess-supply function of region $2\left(E S_{2}\right)$. Under these conditions, region 1 ships quantity $E_{1}$ to region 2 to fulfill the excess demand $\left(E D_{2}\right)$. The price in region 2 equals the price in region 1 plus the transportation costs, or $P_{2}=P_{1}+T_{12}$. The two-region case may be generalized to the multi-region situation, and the problem stated in a linear programming framework.

Empirical studies using this model have treated supply in one of three ways. First, product supply has been considered to be predetermined with regional supply functions perfectly inelastic at specified quantities. Henry and Bishop's (1957) study of the broiler industry illustrates the general approach using a transportation model. ${ }^{5}$ Judge and Wallace's (1959) study of beef illustrates the spatial equilibrium formulation employing demand functions and inelastic supply functions.

A second approach has been to de-

\footnotetext{
${ }^{5}$ For a discussion of the nature of the transportation model, see Dorfman, Samuelson, and
} Solow (1958) or other well-known texts covering linear programming and related techniques. 
velop cost of production data by region and proceed to minimize the combined transportation and production costs in meeting regional demand. This approach was used by Henderson (1958) in an analysis of the efficiency of the coal industry; by Snodgrass and French (1958) in a study of the dairy industry; and by Dennis and Sammet (1961) in one model employed in an analysis of the strawberry industry. It is generally assumed that the costs of labor and other inputs do not vary with the level of regional production. This appears to be reasonable for changes in production of items that are of relatively minor importance in the economy of any given region. A supply function is generated that is perfectly elastic at the estimated cost level.

A third approach, illustrated in the Fox-Taeuber (1955) analysis for the feed-livestock economy considers a joint equilibrium for the intermediate product (feed) and the final product (livestock). For each region, functions were specified for the demand and supply of livestock and the demand and supply of feed. Production of feed was assumed to be predetermined, with the resulting inelastic supply function. The model was solved using two linear programs; one for feed prices and shipments and the other for livestock prices and shipments. The solution procedure was to take a particular set of [assumed] values for the unknowns in the livestock market and solve the feed problem; then taking the feed prices and quantities as given, solve the livestock problem, and so on until a simultaneous solution of equilibrium prices and shipments was obtained. This was eased by the nature of the supply function for livestock which expressed quantity as a function of the price of livestock and the price of feed.

The model by Fox and Taeuber illustrates that for certain types of production where the shipments of intermediate products must be considered in determining the location of production, it is necessary to introduce additional considerations into the one-product model. The Lefeber model of spatial general equilibrium illustrates that it is possible to introduce the shipment of intermediate products into a single linear programming framework (Lefeber, 1958, p. 111). His model specifies linear homogeneous production functions for all products with given fixed production coefficients. Thus, there is a unique combination of factors used in the production of each good. In the present model, it is desirable to consider alternative combinations of factors. Dorfman, Samuelson, and Solow (1958) indicate that in a general equilibrium model, it is possible to maintain equilibrium conditions with the introduction of alternative production processes for each product. They note that although the introduction of alternative production processes does introduce additional considerations, the model "comes out very much like the Walras-Cassel model... (Dorfman et al., 1958, p. 356. See also pp. 346-81).

The present model may be characterized as a partial equilibrium analysis that specifies alternative production processes for the conversion of intermediate products into final product. Equilibrium flows are obtained for the product and for the intermediate products. The theoretical approach thus follows the model of Lefeber but introduces alternative production processes. A demand function is used rather than given regional prices, following the study by Judge and Wallace. The basic problem faced parallels that of Fox and Taeuber although here a partial equilibrium analysis of one segment of the feed-livestock economy is analyzed. The model of feedlot location is specified in detail in the following section.

\section{A MODEL OF LOCATION}

The location of feedlots in various regions of the country depends on a set of interdependent relationships, especially in the feed-livestock economy. In 
the aggregate, these relationships involve regional demand for various livestock products; production functions for livestock products and for intermediate goods such as feeds and feeder cattle; regional availability of factors of production; and transfer cost functions for both products and intermediate products that tie regions together in a spatial equilibrium sense. The analysis of the location of a particular industry, such as feedlot operations, is undertaken in a partial equilibrium framework and thus does not trace through the effects of changes in feedlot location on the related segments of the feed-livestock economy. Further, this model is static and relates to cattle marketed from feedlots for a single year, 1958. A 20-region breakdown of the United States is used. The model does not allow for seasonal demand conditions or seasonal availability of feed and feeder cattle, although these factors could be incorporated into the model. The model used in analyzing the location of feedlots is specified next.

Assume there exists a fixed number of points that may be taken to represent regional production and consumption centers. Each point represents an area with given quantities of factors such as land, labor, and capital which are assumed to be available at given cost levels for feedlot operations. Further, each region has available given quantities of intermediate products-namely, feeder cattle, feed concentrates, and hay or other roughages-which are available for feedlot finishing of beef in that region or for shipment to other regions. Similarly, slaughter weight cattle or meat can be shipped from producing regions (which are to be determined in the model) to meet regional levels of demand for beef as specified in the demand functions. Transfer functions are given which specify the unit cost of shipping intermediate products and the final products among regions. Production activities are specified which relate input requirements per unit of output in the production of slaughter weight cattle. The problem is to determine that regional organization of cattle feeding, intermediate and final product shipment pattern, and beef prices that would result under competitive conditions.

The model thus requires specifications as to: (1) the regional availability of factors; (2) the production process for conversion of intermediate products into meat; (3) the regional demand for beef; and (4) the transfer costs for intermediate products and final products. Two other aspects of the model may be noted briefly.

Slightly over one-half of the beef consumed comes from sources other than feedlots. This includes grass-fat cattle, cull animals both from dairy and beef stock, as well as imports of meat and slaughter cattle. In this partial equilibrium approach, the regional supply of beef that is not feedlot finished, which will be referred to as nonfed beef, is taken as predetermined at estimated 1957-58 levels with that supply independent of feeding operations. Nonfed beef is considered to be a direct substitute for fed beef, to meet the demand for beef both within the region and for shipment to other regions in three of the models to be discussed. A distinction between fed and nonfed beef is introduced, however, in the fourth model to test the validity of this specification.

The second aspect relates to slaughter costs and location. We assume that slaughtering cost equals by-product value in all regions.' Thus, the supply of slaughtering services is treated as perfectly elastic at the price represented by the by-product values. The location of slaughter plants at consuming centers or at feedlot locations then will depend on the relative rail rates for

\footnotetext{
${ }^{6}$ Determination of the accuracy of this assumption would involve consideration not only of regional differences in slaughtering plant costs, but the markets and transportation costs for byproducts as well.
} 
slaughter animals and meat. Transfer cost functions, as calculated, always favored meat shipments, and thus slaughter plants are specified at feedlot locations. The location of plants near feeding areas is consistent with the trend towards decentralized slaughter locations.

\section{Regional Availability of Factors}

Supply functions for feeder calves. The location of the basic breeding herds (beef cows two years old and over) is taken as predetermined, and thus the regional supply of feeder calves also is given for a particular year. Further, we assume that there are no differences in the quality of the cattle, and that feeders are of a uniform weight of 650 pounds at these production regions. This, of course, abstracts from reality in that there may be important differences in the weights at which calves are shipped out of a region and sold. For example, lighter-weight animals may be shipped from mountain regions and used as stockers to take advantage of seasonal range available in areas such as the western coastal areas, or the use of pasture and other roughage supplies, such as sugar beet tops, in various regions of the country. Also, the quality of feeder cattle is taken as an average quality and this may bias results from one section of the country to another.

It is argued that the location of the beef cow herds may be taken as given with their location primarily determined by the availability of range and pasture lands for which little alternative use exists. Thus, the breeding herds are located in relation to resources such as rangeland from which the flow of product may be measured in terms of animal units of grazing. In general, the output is nontransportable. Thus, breeding herds are located to utilize the nontransportable resource flow.

The cattle feeder does compete for feeder cattle in a sense with producers requiring replacement stock. However, if the model is nondynamic in the sense of disregarding cyclical buildups and depletions of breeding herds, a fixed percentage of the calf crop may be assumed as available for sale, in this case as yearlings.

Supply function of feed concentrates and roughage. The production of feed concentrates and roughages produced on cropland is considered as predetermined for a particular year, the time horizon of this analysis. The stocks at the beginning of the year also are given quantities. Thus, the supply function for all feed is inelastic. Feeds within the feed concentrate group are considered perfect substitutes in terms of net energy, and the same assumption is made for feeds within the roughage category.

The demand for feeds for industrial use, end-of-year carryover, and for livestock other than cattle fed in feedlots is assumed as given by region. This assumption, one of the most limiting of the analysis, is required if the partial analysis of feedlot cattle is to be undertaken. The model could be enlarged to specify production functions for all types of livestock and a more satisfactory theoretical framework obtained for an analysis of the feed-livestock economy. However, this analysis allows for tests of alternative specifications as to the feedlot operations which are required under the present knowledge of production coefficients, demand function coefficients, and transportation coefficients. This assumption implies that other segments of the livestock economy are in relative-equilibrium and that adjustments are most apt to take place in the location of feeding-providing the results indicate locations other than currently found. What justification can be offered for the reasonableness of this specification?

The location of cattle feeding is less clear-cut than for the production of milk for fluid use or the production of hogs, for example. Milk production for fluid use tends to be market oriented whereas hog production tends to be feed 
source oriented. This may be illustrated as follows:

1. Determine the pounds of feed concentrates required per 100 pounds of product.

2. Determine the ratio of transfer cost per 100 pounds of product to the transfer cost per 100 pounds of concentrates.

3. If item (1) exceeds (2), production will tend to be feed-source oriented; if the reverse is true, production will tend to be market oriented.

A ranking of livestock products, as reported by King (1961, p. 13) indicates that production as to feed-source orientation would be as follows: hog production, especially if product shipped as fresh pork rather than live animals; butter production; broiler production; eggs shipped 500 miles or less. Marketoriented production would include eggs, if shipments of 1,000 miles are required, and fluid milk production. This analysis considered shipments of concentrates only, and for this specification, production of feedlot cattle and shipments of carcass beef rather than live animals would rank lower than butter production in its feed-source orientation. The fact that feeder cattle as well as roughage also are transportable prompted the more complete analysis of location attempted here. The model takes as given the livestock production levels for other than feedlot produced beef. Thus, from the regional supply functions for feed, we subtract the quantity that is fed to livestock other than feeder cattle, used industrially, or used as end-of-year stocks. $^{7}$

Supply functions of other inputs. The regional level of feeding is not considered of significant magnitude to materially affect prices for such inputs as labor; building materials, fuel and power, mineral feeds, and other minor factors used in feedlot operations. Feedlot requirements for land, as contrasted to most agricultural production, are of minor importance. Thus in the model, land, labor, and capital are not considered as limiting factors in determining location.

\section{The Production Process}

Production activities are specified relating the quantity of the intermediate products of feeder cattle, feed concentrates, and roughage to output of slaughter-weight cattle. The weight of feeder cattle is standardized to a 650 pound animal of uniform quality, and feed inputs are in units of net energy. Nine feeding activities differing as to the level of weight gain and concentrateroughage ratio are specified for each region. Feed conversion efficiency differences among regions were introduced in some models, based on reported feeding trial data.

Nonfeed costs in feedlot operations are specified for each of the production activities. Within a region, these costs differ among production activities depending upon the time required for gain. For example, the time required for a given gain will be longer for a ration consisting of a low concentrateroughage ratio than for a ration with a high concentrate-roughage ratio. The level of nonfeed costs varies among regions depending upon the type of lot required (shelter needed in some areas) and the wage costs. No economies of scale in feedlots are considered; that is, the nonfeed costs are taken to represent a long-run average cost point.

The production function facing the region is taken to be linear and homogeneous. This implies that for any proportional increase in the number of feedlots operating in a region, there will be a proportional increase in the factor requirements. The number of cattle fed in a region is determined simultaneously with the equilibrium flow of factors determined in the model, rather than among regions, with given demand levels and transportation cost functions. The

\footnotetext{
${ }^{7}$ This may result in negative quantities available in some regions. This does not introduce complications in the model, except that before shipments can be made for production of beef, the deficit shipments must be met.
} 
cost of feeding in a region thus will be determined in the model, rather than determined on the basis of existing costs, as was done in the Dennis-Sammet (1961) model.

\section{Demand for Beef}

The quantity of beef consumed in each region is specified as a function of price, population, and per capita income. No account is taken of supplies or

\section{Section A: Interregional Meat-Price Relationships}

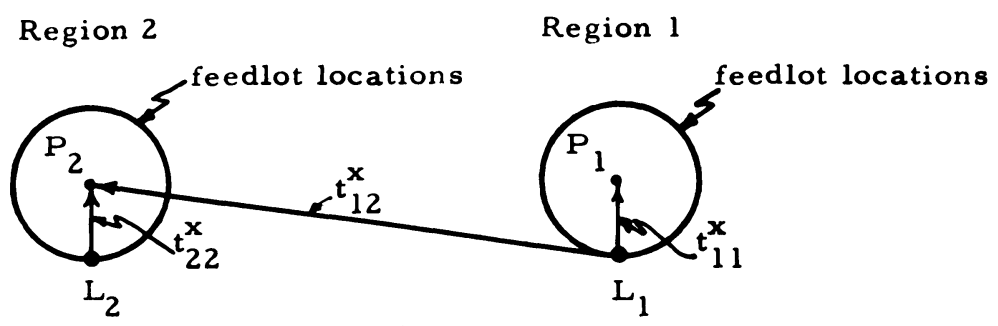

Section B: Interregional Feed-Price Relationships

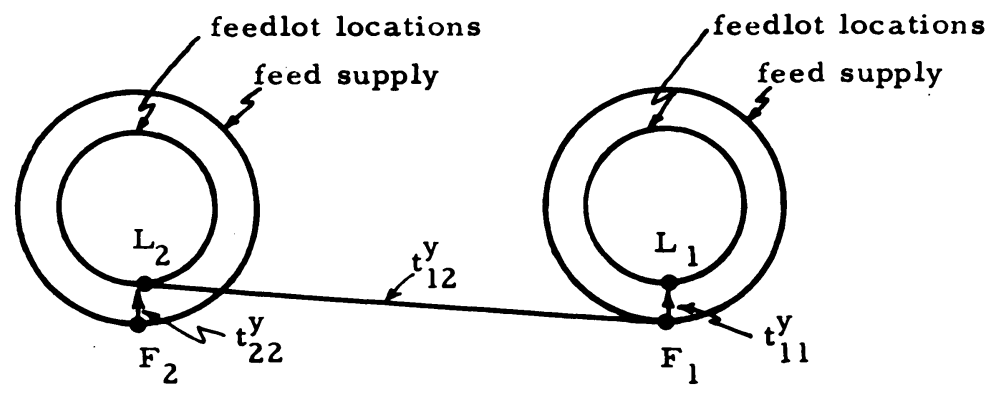

Region 2

Region 1

Fig. 2. Basis for model intermarket price relationship for final product (meat) and for intermediate products (illustrated for feed) for a two-region case. 
prices of other meats, and no distinction is made between beef from feedlot finishing and from other sources. ${ }^{8}$

\section{Transfer Costs}

Each region is represented by a central point used for calculating transfer costs between regions. Feedlot locations and slaughter plants are assumed to be located identically. On the basis of comparisons of derived interregional rail transfer costs, shipments are assumed to be as meat rather than as slaughterweight animals. Intraregional transfer costs, based on truck costs, are allowed for by assuming standard average distances of feeding locations from the representative central points. This is illustrated in figure 2 , section $\mathrm{A}$, for product shipments. The feedlot location is assumed to be at a point 50 miles from the central point in each region, indicated as $L_{1}$ and $L_{2}$ for the respective regions. A feedlot operator in surplus-producing region 1 , located at $L_{1}$, is faced with the alternative of shipment within the region (market price $P_{1}$ less within-region truck transfer cost $t^{x}{ }_{11}$ ) or shipment to another region (market price $P_{2}$ less interregional transfer cost $t^{x}{ }_{12}$ ). In the model, within- or between-region transfer costs are deducted from market prices to obtain net prices facing feedlot operators in the various regions.

This adjustment for product shipments represents a slight adjustment from the point-trading model to allow for intraregional transfer costs. Thus, market prices between trading areas will differ by interregional transfer cost $\left(t^{x}{ }_{12}\right)$ less intraregional transfer cost $\left(t^{x}{ }_{11}\right)$ or $P_{2}=P_{1}+\left(t^{x}{ }_{12}-t^{x}{ }_{11}\right)$. The derived price facing feedlot operators in the two regions also will differ by this net interregional transfer cost.

Intermediate product transfer costs between regions are represented by rail costs minus within-region truck costs. The use of net transfer costs thus evaluates the relative ability of surplus or deficit regions to bid for feed or feeder supplies at the feedlot location. Feed concentrates, for example, are assumed to be available within a distance of 25 miles of the feedlot site, as illustrated in figure 2, section B. Using a similar argument as for product shipment, the price of feed received by a corn producer located at point $F_{1}$ is determined by the relative bidding power of the feedlot operators located at points $L_{1}$ and $L_{2}$. In equilibrium with factor shipment, the price of corn at feedlot location $L_{1}$ will differ from that of feedlot location $L_{2}$ by the net interregional transfer cost $\left(t^{y \prime}{ }_{12}\right)$ where $t^{y \prime}{ }_{12}=t^{y}{ }_{12}-$ $t^{y}{ }_{11}$. Prices at the producer level for grain $\left(\boldsymbol{F}_{1}, \boldsymbol{F}_{2}\right)$ will also differ by this cost difference.

\section{MATHEMATICAL MODEL}

The regional availability of the intermediate products of feeder cattle, feed concentrates and roughage is considered

\footnotetext{
${ }^{8}$ One model developed in this report specifies equal proportions of fed and nonfed beef, by region.

${ }^{9}$ To illustrate, if corn shipments are made from region 1 to region 2 with cattle feeding in both regions, we may express the interrelationships among prices at $L_{1}, L_{2}, F_{1}$ and $F_{2}$. Assume the following values: the price of corn per bushel at $L_{2}$ equals 130 cents; intraregional transfer costs $\left(t^{y}{ }_{11}\right.$ or $\left.t^{y}{ }_{22}\right)$ equal 6 cents per bushel; transfer cost from region 1 to $2\left(t^{y}{ }_{12}\right)$ equals 30 cents. Prices at various locations are as follows:
} LOCATION $\quad$ PRICE (CENTS PER BUSHEL)

Grain deficit area:

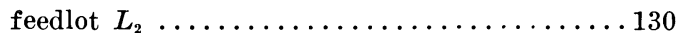

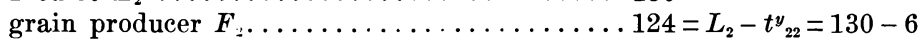

Grain surplus area:

grain producer $F_{1} \ldots \ldots \ldots \ldots \ldots \ldots \ldots L_{2}-t^{y}{ }_{12}=130-30$

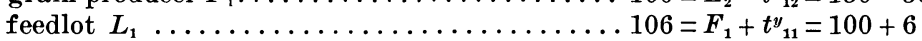

Difference :

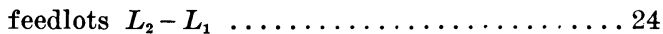

grain producers $F_{2}-F_{1} \ldots \ldots \ldots \ldots \ldots \ldots \ldots \ldots 24$ 
TABLE 1

Notation Relating to Location Model

\begin{tabular}{|c|c|c|c|c|c|c|}
\hline \multirow{2}{*}{ Item } & \multicolumn{3}{|c|}{ Intermediate products } & \multicolumn{3}{|c|}{ Beef } \\
\hline & Feeder cattle & Conc. feed & Roughage & Fed & Nonfed & Total \\
\hline Quantity available in region $i .$. & $W_{i}$ & $Y_{i}$ & $Z_{i}$ & & $X_{i}$ & \\
\hline Quantity produced in region $i$. & & & & $X_{i}^{\prime}$ & & \\
\hline Quantity used or demanded in $i$ & $W^{i}$ & $Y^{i}$ & $Z^{i}$ & & & $\sum X_{j i}$ \\
\hline Quantity shipped from $i$ to $j \ldots$ & $W_{i j}$ & $Y_{i j}$ & $Z_{i j}$ & & & $X_{i j}$ \\
\hline Transfer cost per unit shipped ${ }^{*}$ & $t_{i w^{w^{\prime}}}$ & $t_{i} i^{y^{\prime}}$ & $t_{i j^{\prime}{ }^{\prime}}$ & & & $t_{i j^{x}}$ \\
\hline $\begin{array}{r}\text { Price at slaugher plant in region } \\
i \text { for carcass beef shipped to } \\
\text { region } j \ldots \ldots \ldots \ldots \ldots \ldots \ldots\end{array}$ & & & & & & $P_{i j} \dagger$ \\
\hline
\end{tabular}

* Net transfer costs for intermediate product $\left(t_{i j} w^{\prime}=t_{i j} j^{w}-t_{i i^{w}}\right)$ and gross transfer costs for carcass beef.

$\dagger P_{i j}=P_{j}-t_{i j}{ }^{x}$ where $P_{j}$ is price at market location. The slaughter plant location is specified at the feedlot location in this model.

to be predetermined. The notation used in describing these and other variables of the model is summarized in table 1 with a few exceptions to be noted. Transfer costs per unit of final product or intermediate product are a function of distance shipped and considered not to be influenced by the volume shipped. The terminology used in describing the production process and the demand for beef will be noted next, followed by a mathematical statement of the problem.

The production relation between beef produced and factor use, from which production activities are specified, is as follows:

$$
X_{i}^{\prime}=f\left(W^{i}, Y^{i}, Z^{i}\right)
$$

The nonfeed costs per head fed vary with the ration fed, the length of time on feed, and among regions with the labor and construction specifications, and are related to the following:

$$
\begin{aligned}
q^{i}= & \text { nonfeed costs per head per day } \\
& \text { in region } i \\
D_{i}= & \text { number of days on feed in re- } \\
& \text { gion } i
\end{aligned}
$$

where

$$
D_{i}=f\left(\frac{Y^{i}}{W^{i}}, \frac{Z^{i}}{W^{i}}\right)
$$

The demand for beef may be expressed as follows:

where

$$
X_{j i}=f\left(P_{i}, I_{i}, N_{i}\right)
$$

$P_{i}=$ price of carcass beef in region $i$

$I_{i}=$ per capita income in region $i$

$N_{i}=$ population in region $i$.

The problem is to determine the regional organization of cattle feeding, product and factor shipment and beef prices that would result from perfectly competitive behavior under the assumptions of the model. Since a demand function is used, the solution of the problem is obtained by specifying an initial set of regional beef prices, maximizing the value of the final product minus the cost of transfer of factors and product subject to certain restraints, and then using an iterative process to bring regional prices and quantities consumed into equilibrium. The function to be maximized may be expressed as follows:

Maximize

$$
\begin{aligned}
& \sum_{i} \sum_{j} X_{i j} P_{i j}-\sum_{i} \sum_{j} W_{i j} t_{i j}^{w^{\prime}} \\
& -\sum_{i} \sum_{j} Y_{i j} t_{i j}^{Y^{\prime}}-\sum_{i} \sum_{j} Z_{i j} t_{i j}^{Z^{\prime}} \\
& -\sum_{i} W^{i} D_{i} q_{i}
\end{aligned}
$$




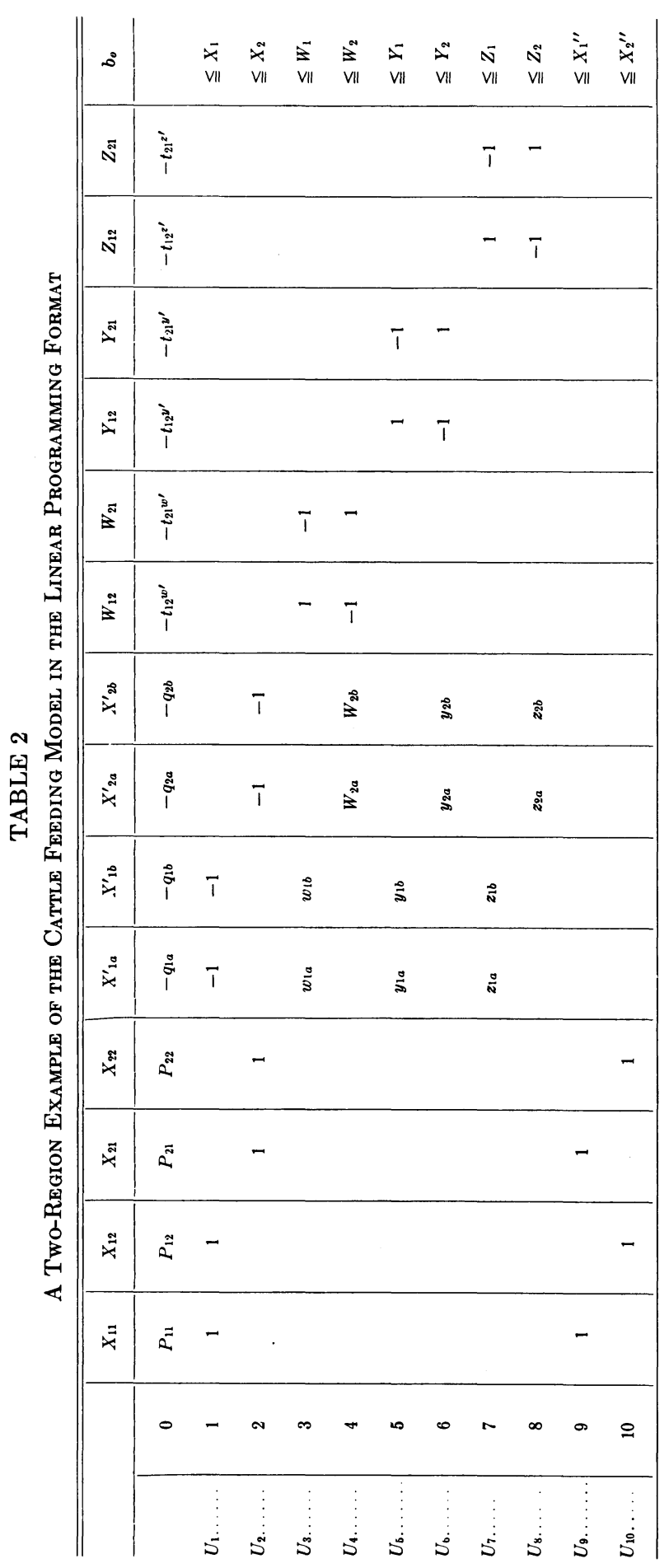


subject to:

(1) Relation governing shipments and production of beef:-The shipment from any one region to itself and to other regions must equal the nonfed beef plus fed beef produced; or

where

$$
\sum_{j} X_{i j}=X_{i}+X_{i}^{\prime}
$$

$$
X_{i}^{\prime}=f\left(W^{i}, Y^{i}, Z^{i}\right) .
$$

(2) Supply relations governing the distribution of factors:-The quantity of factors used in any region is equal to or less than that available in the region plus inshipments less outshipments; or

$$
\begin{aligned}
& 0 \leqq W^{i} \leqq W_{i}+\sum_{j} W_{j i}-\sum_{j} W_{i j} \\
& 0 \leqq Y^{i} \leqq Y_{i}+\sum_{j} Y_{j i}-\sum_{j} W_{i j} \\
& 0 \leqq Z^{i} \leqq Z_{i}+\sum_{j} Z_{j i}-\sum_{j} Z_{i j}
\end{aligned}
$$

$0 \leqq X_{i j}, W_{i j}, Z_{i j}$.

(3) Equilibrium condition in the regional beef market:-The shipments of beef to a particular region, including shipments from that region itself, must be consistent with the regional set of prices; or

$$
\sum_{j} X_{j i}=X_{i}^{\prime \prime}=f\left(P_{i}, I_{i}, N_{i}\right)
$$

where $X_{i}{ }^{\prime \prime}$ is the quantity of beef consumed in region $i$ under a given set of prices.

The equilibrium solution is thus obtained when the specified set of prices for beef are consistent with the equilibrium prices, and similarly for the quantity of beef consumed.

\section{LINEAR PROGRAMMING FORMULATION}

The linear programming formulation of this problem includes 100 equations and 1,416 activities. Equations are required for each of 20 regions for 5 types of data; namely, nonfeedlot beef availability $\left(X_{i}\right)$, requirements and availability of feeder cattle $\left(W_{i}\right)$, concentrates $\left(Y_{i}\right)$ and roughages $\left(Z_{i}\right)$, and feedlot beef $\left(X^{\prime}{ }_{i}\right)$. The 1,416 activities are as follows:

meat shipments $\left(X_{i j}\right) 20$ origins $\times$ 20 destinations $=400$

feeding activities $\left(V_{i j}\right) 9$ activities $\times 20$ regions $=180$

factor shipments (excluding intraregional shipments $)^{10}$

feeder cattle $\quad\left(t^{w \prime}{ }_{i j}\right) 20$ origins $\times 20$ destinations $=400-20$

concentrates $\left(t^{y \prime}{ }_{i j}\right) 11$ origins $^{10} \times 20$ destinations $=220-11$

roughages $\quad\left(t^{z \prime}{ }_{i j}\right) 13$ origins $^{10} \times 20$ destinations $=260-13$.

The programming format of the problem is illustrated in table 2 for a simplified two-region case with only 2 feeding activities for each region. " Beef requirements for region 1 may be met by availability of nonfed beef $\left(X_{1}\right)$, or fed beef $\left(X^{\prime}{ }_{1}\right)$ produced in the region or shipped in from the other region $\left(X_{21}\right)$. Production of feedlot beef in region 1 is obtained either from feeding activity $\left(X^{\prime}{ }_{1 a}\right)$ or from activity $\left(X^{\prime}{ }_{1 b}\right)$. The factor requirements per unit of production using activity $X^{\prime}{ }_{1 a}$ include feedlot nonfeed costs $\left(q_{1 a}\right)$; feeder calves $\left(W_{1 a}\right)$; feed concentrates $\left(y_{1 a}\right)$; and roughage $\left(z_{1 a}\right)$, and similarly for activity $X^{\prime}{ }_{1 b}$. Data in column $b_{o}$ relate to the availability of factors $\left(W_{i}, Y_{i}, Z_{i}\right)$; and the quantity of total beef $\left(X_{i}{ }^{\prime \prime}\right)$ consistent with the regional prices for beef $\left(P_{j}\right)$. As a set of beef prices is changed in successive runs of the problem, the quantity data for feed beef $\left(X_{i}{ }^{\prime \prime}\right)$ are also changed to be consistent with the demand function.

The numbers represented by $U_{i}(i=1$,

\footnotetext{
${ }^{10}$ For regions that are deficit in feed concentrates and/or roughages, transportation costs for outshipments are irrelevant.

11 This presentation is adapted from that given by Lefeber (1958) for a model specifying production of several products whereas the present model specifies nine possible production activities for the production of one product.
} 
$2, \ldots, 10$ ) in table 2 are shadow prices generated from the corresponding dual problem. The following interpretation may be placed on these numbers. $U_{1}$ and $U_{2}$ are imputed prices for beef at slaughter plant (and feedlot) locations in the first and second regions, respectively. When a final solution has been reached they will correspond exactly to the prices used in the objective function. Prices imputed to feeder cattle delivered to the feeding location are represented by $U_{3}$ and $U_{4}$. Similarly $U_{5}, U_{6}$, $U_{i}$, and $U_{8}$ represent prices of feeds at the feeding location. Since the supplies of factors are given and fixed, the prices are rents-each in accord with the factor's marginal value product. $U_{9}$ and $U_{10}$ represent the difference between the prices appearing in the objective function (i.e., $P_{11}, P_{22}$ ) and the prices im- puted to beef $\left(U_{1}, U_{2}\right)$ in regions 1 and 2 , respectively. As successive applications of the program approach an equilibrium solution, these numbers $\left(U_{9}\right.$, $\left.U_{10}\right)$ approach zero.

In some cases the quantity of one or both of the feeds available for beef feeding may in fact be negative. The application of the model is not affected in any way. The size of the final model may be calculated from inspection of the sample problem shown in table 2 . There are $5 n$ equations and $4 n^{2}+$ $(k-3) n$ where $n$ is the number of regions and $k$ is the number of activities used to represent the production process. The actual problem involves somewhat fewer activities because activities involving shipments of factors from deficit regions are omitted. They would not be included in an optimum solution.

\section{BASIC DATA AND FUNCTIONAL RELATIONSHIPS}

\section{REGIONAL DEMARCATION}

No accepted criteria are available for the breakdown of a geographic area into regions and, thus, the procedure is largely subjective. However, the particular breakdown selected may affect the results considerably. The detail acquired through a finer breakdown must be weighed against the fact that the computational burden increases approximately with the square of the number of regions. Twenty regions were considered a practical maximum and the demarcation was made accordingly.

The criteria considered in making the breakdown include: consideration of natural barriers to transportation; availability of data (generally whole states); expected commodity moves were east-west and, therefore, northsouth boundaries seemed more flexible; homogeneity of agricultural production; shipping distances between adjacent regions should be about equal; regions should coincide with population and factor-producing concentrations; the study is oriented toward adjustment problems in the western states.
It is apparent that not all the above criteria may be met in a 20 -region breakdown. The actual breakdown then is a compromise among them. It was also necessary to select a set of shipping points to represent the regions selected. Ideally, a different point in the region would be selected to represent the "center of gravity" for each commodity represented in the model. In the interest of simplifying the task, only one point is used for each region. These points were selected central to the concentration of population, cattle, and feed production. The regions and shipping points selected are shown in figure 3.

\section{REGIONAL FEED SUPPLY}

\section{Concentrates}

The regional use of feed concentrates other than for beef cattle feeding is considered as predetermined for the year beginning October 1, 1957. Further, all feeds are assumed to be directly substitutable in terms of net energy. The supply variable used in the analysis equals the regional supply of feed concentrates (as defined below) minus the regional 


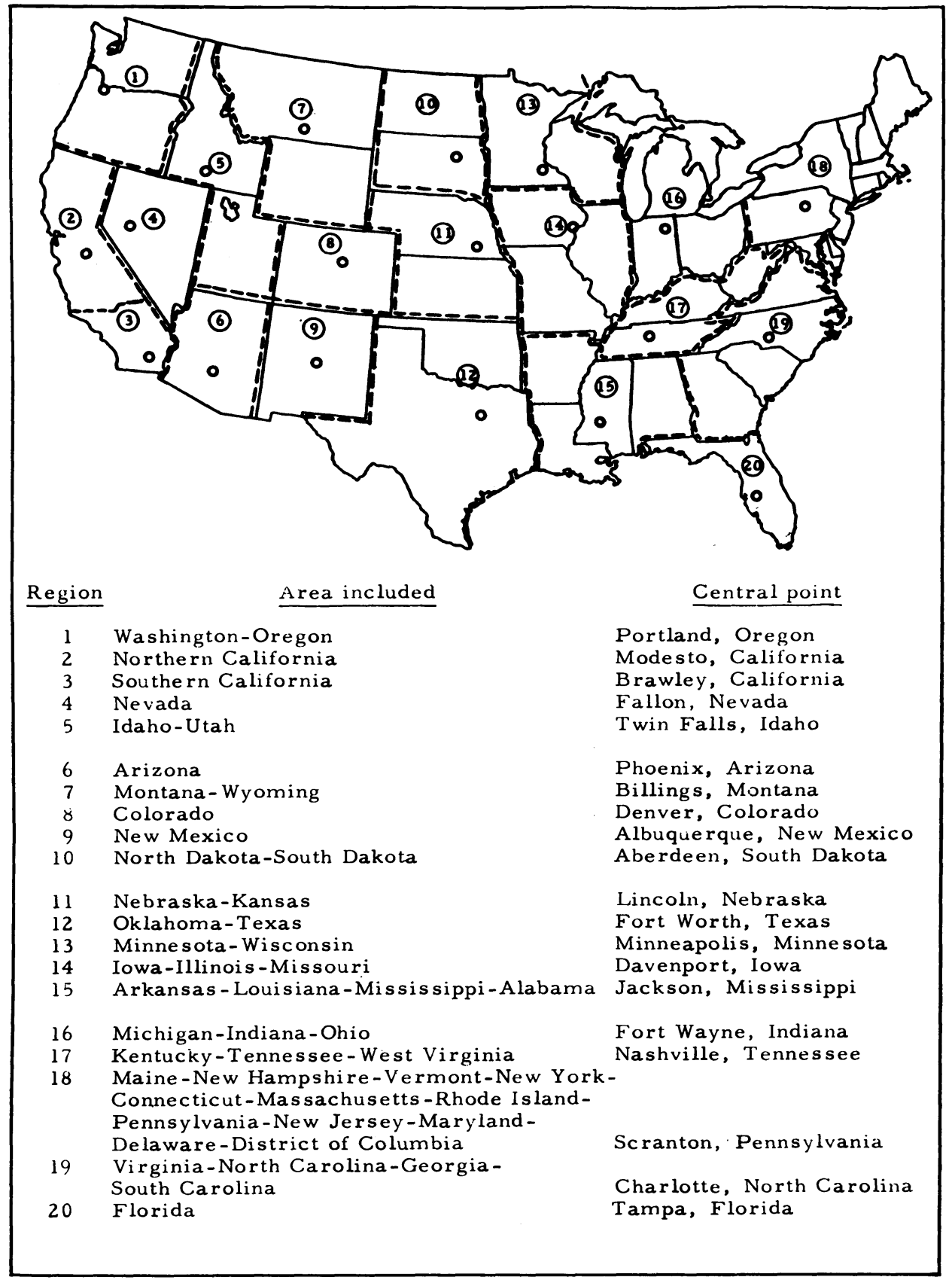

Fig. 3. Regions and central points used in location model. 
TABLE 3

Regional Concentrate Availability Expressed in Terms of Net Energy and Corn Equivalent

(For year beginning October 1, 1957)

\begin{tabular}{|c|c|c|c|c|}
\hline \multirow{2}{*}{ Region } & \multirow{2}{*}{$\begin{array}{l}\text { Available for } \\
\text { all livestock* }\end{array}$} & \multirow{2}{*}{$\begin{array}{c}\text { Fed to livestock } \\
\text { other than } \\
\text { beef cattle } \dagger\end{array}$} & \multicolumn{2}{|c|}{ Available for beef cattle in terms of: } \\
\hline & & & Net energy & Corn equivalent $\ddagger$ \\
\hline & \multicolumn{3}{|c|}{1,000 therms } & 1,000 tons \\
\hline 1. & $1,312,856$ & $2,512,328$ & $-1,199,472$ & $-\quad 749$ \\
\hline 2 . & $2,803,583$ & $3,688,048$ & $-\quad 884,465$ & $-\quad 552$ \\
\hline 3. & $1,196,094$ & $2,551,003$ & $-1,354,909$ & -846 \\
\hline $4 \ldots$ & 11,184 & 109,837 & $\begin{array}{l}-\quad 98,653 \\
\end{array}$ & - \\
\hline 5. & $1,703,756$ & $1,497,496$ & 206,260 & 129 \\
\hline 6. & 776,980 & 284,648 & 492,332 & 307 \\
\hline 7. & $1,982,126$ & 986,986 & 995,140 & 621 \\
\hline 8. & $2,386,074$ & $1,000,909$ & $1,385,165$ & 865 \\
\hline $9 \ldots$ & 377,578 & 312,494 & 65,084 & 41 \\
\hline $10 .$. & $12,492,642$ & $6,205,017$ & $6,287,625$ & 3,925 \\
\hline 11. & $21,047,230$ & $9,552,725$ & $11,494,505$ & 7,175 \\
\hline 12. & $8,229,340$ & $7,838,649$ & 390,691 & 244 \\
\hline $13 \ldots \ldots$ & $27,185,157$ & $21,506,394$ & $5,678,763$ & 3,545 \\
\hline $14 \ldots \ldots$ & $68,093,540$ & $48,238,554$ & $19,854,986$ & 12,394 \\
\hline $15 \ldots$ & $3,811,247$ & $9,970,415$ & $-6,159,168$ & $-3,845$ \\
\hline 16. & $26,569,850$ & $20,723,612$ & $5,846,238$ & 3,649 \\
\hline $17 .$. & $6,339,754$ & $8,152,690$ & $-1,812,936$ & $-1,132$ \\
\hline $18 \ldots$ & $5,365,422$ & $19,371,534$ & $-14,006,112$ & $-8,743$ \\
\hline $19 .$. & $8,000,213$ & $14,722,799$ & $-6,722,586$ & $-4,196$ \\
\hline 20 & 709,789 & $1,953,861$ & $-1,244,072$ & $-\quad 777$ \\
\hline United States. & $200,394,415$ & $181,179,999$ & $19,214,416$ & 11,994 \\
\hline
\end{tabular}

* See Appendix A for basic data and conversion from tons to net energy.

$\dagger$ Based on concentrate use as reported by King (1961) and converted to net energy assuming 1,547 therms per ton, the weighted average content of concentrate feeds fed in 1957-58.

$\ddagger$ Converted on the basis of 1,602 therms per ton.

use of concentrates other than for cattle feeding. Regional supply of feed concentrates is defined here as beginningyear stocks plus production plus foreign imports to relevant regions. Regional use of feed concentrates other than for cattle feeding is the sum of quantities fed to livestock other than cattle on feed, foreign exports, industrial, food and seed uses, and yearending stocks. The difference between regional use (including that for cattle on feed) and regional supply is accounted for in interregional shipments of feed concentrates. The basis for quantifying the supply variables is a study by King (1961) of the supply and distribution of feed concentrates in 195758.
The quantity of concentrate feed available for all livestock and for beef cattle feeding, the variable used in this study, is shown in table 3 expressed in terms of net energy. For nine regions, the net availability of concentrates is shown as a negative quantity. This occurs in regions for which interregional concentrate shipments are required to meet the actual feed used other than for beef cattle feeding. From a computational point of view, this means that shipments must be made to satisfy these deficits before additional quantities may be shipped to that region for the production of beef. From a theoretical view, it implies that uses other than cattle feeding would have first claim on available feed supplies both intra- and inter- 
TABLE 4

Regional Roughage Avallability Expressed in Terms of Net Energy and Alfalfa Hay Equivalent*

(For year beginning October 1, 1957)

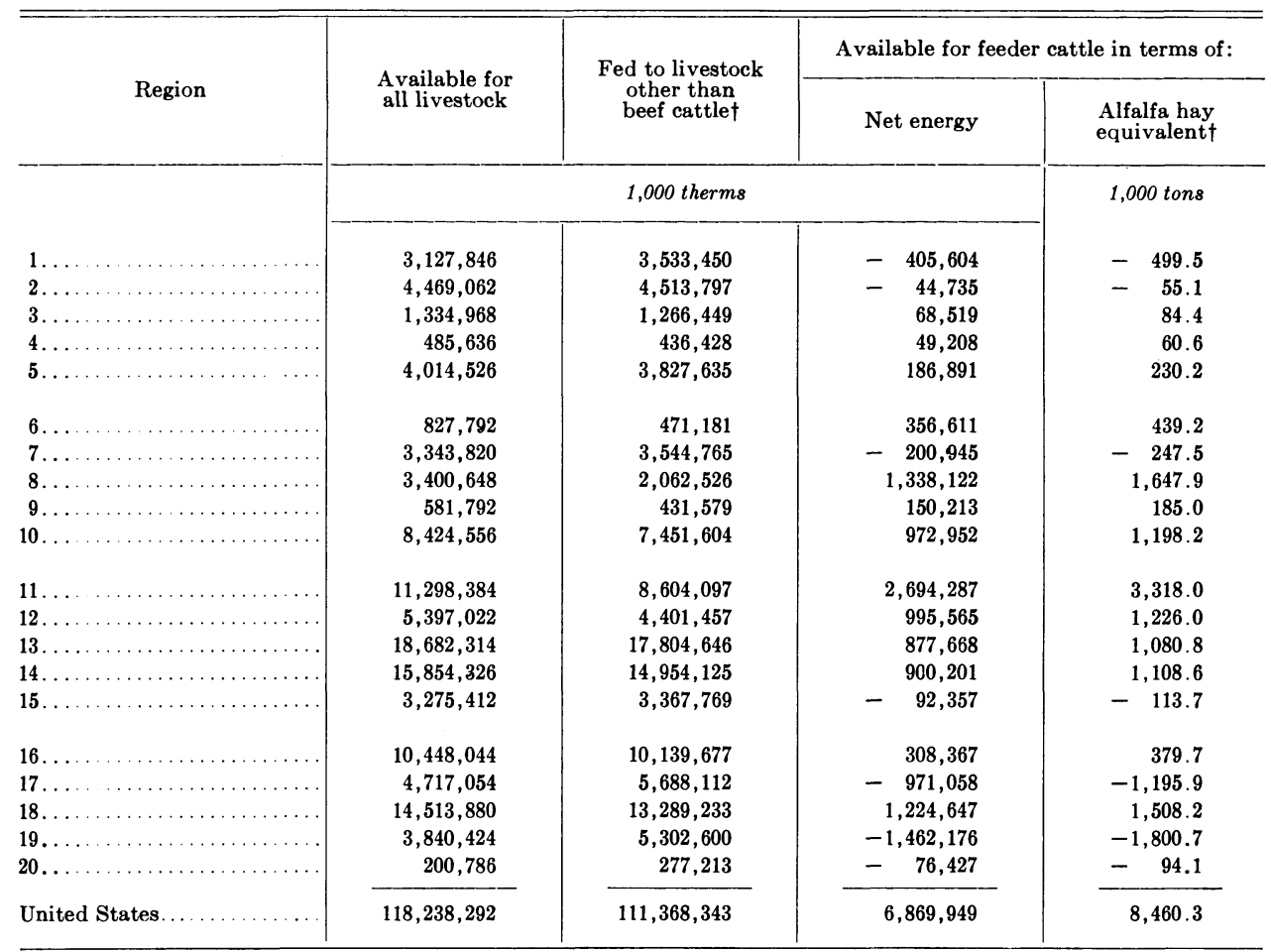

* The basic data on availability and use are presented in Appendix A.

† Converted on the basis of 812 therms per ton.

regionally. This may tend to bias the results toward a feed-source orientation of feedlot operations.

\section{Roughage}

The supply of roughages available for beef cattle feeding by regions was estimated by essentially the same method as described for concentrates. However, the basic data on hay and forage production and the quality variation are such that less reliance can be placed in these estimates. Regional supply of roughage includes total hay production (adjusted for stock changes) less quantity of alfalfa used in meal production; sorghum forage, cottonseed hulls; and grass silage fed. These quantities were converted to net energy expressed in therms. Regional use of roughage was estimated on the basis of sketchy information. Roughage feeding rates in terms of the hay equivalent of quantities fed to milk cows during the winter feeding season are reported by states (U. S. Agric. Marketing Serv., 1959B). These rates were used to obtain an estimate of roughage fed to dairy cattle and other dairy animals. Requirements for the remaining classes of roughage-consuming livestock were based on estimates by Jennings (1954). The average feeding rates adapted for the United States for the various classes of livestock are given in column 1, next page, under table 5 . 
TABLE 5

Cattle on Feed January 1, Marketings and Placements by Quarter 1956-1959

\begin{tabular}{|c|c|c|c|c|}
\hline \multirow{2}{*}{ Item } & \multicolumn{3}{|c|}{13 states } & \multirow{2}{*}{21 states } \\
\hline & 1956 & 1957 & 1958 & \\
\hline & \multicolumn{4}{|c|}{ thousand head } \\
\hline Cattle on feed January $1 \ldots$ & 4,971 & 5,181 & 4,991 & 6,293 \\
\hline \multicolumn{5}{|l|}{ Marketings: } \\
\hline January-March.......... & 2,437 & 2,505 & 2,278 & 2,819 \\
\hline April-June.......... & 2,409 & 2,313 & 2,316 & 2,919 \\
\hline July-September . . . . . . . . . . & 2,196 & 2,349 & 2,643 & 3,059 \\
\hline October-December....... & 2,305 & 2,218 & 2,493 & 2,934 \\
\hline Total........................... & 9,347 & 9,385 & 9,730 & 11,731 \\
\hline \multicolumn{5}{|l|}{ Placements: } \\
\hline October-December*.. & 3,785 & 3,840 & 3,986 & 5,000 \\
\hline 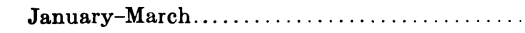 & 1,711 & 1,722 & 2,185 & 2,459 \\
\hline April-June..................... & 1,586 & 1,598 & 1,739 & 2,176 \\
\hline July-September................. & 2,420 & 1,889 & 1,965 & 2,669 \\
\hline \multirow[t]{2}{*}{ 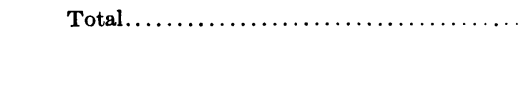 } & 9,502 & 9,049 & 9,875 & 12,304 \\
\hline & \multicolumn{4}{|c|}{ per cent } \\
\hline \multirow{3}{*}{$\begin{array}{l}\text { Relationship of: } \\
\text { Marketings to January } 1 \text { inventory } \ldots \ldots \ldots \ldots \\
\text { Placements to January } 1 \text { inventory } \ldots \ldots \ldots \ldots\end{array}$} & & & & \\
\hline & 188 & 181 & 195 & 186 \\
\hline & 191 & 175 & 198 & 196 \\
\hline
\end{tabular}

* Refers to fourth quarter of year preceding that indicated.

Source: U. S. Department of Agriculture, 1961.

\begin{tabular}{|c|c|}
\hline \multicolumn{2}{|c|}{$\begin{array}{l}\text { TONS OF HAY EQUIVALENT } \\
\text { PER HEAD ON FARMS, } \\
\text { JANUARY } 1\end{array}$} \\
\hline Dairy cows & 3.19 \\
\hline Other dairy & 1.15 \\
\hline Beef cows & 1.00 \\
\hline $\begin{array}{l}\text { Other beef cattle } \\
\text { except cattle }\end{array}$ & \\
\hline on feed & .75 \\
\hline Horses and mules & 1.35 \\
\hline Sheep and lambs & .10 \\
\hline
\end{tabular}

The roughage available for all cattle and for beef cattle is shown in table 4 both in terms of net energy and alfalfa hay equivalent. Seven of the 20 regions are deficit in roughage. Some of the deficits appear unreasonably large. The magnitude of the interregional shipments is unknown; thus, the only reasonable basis for adjustment of the feeding rates by region is absent. The magnitude of the estimates of deficits and surpluses is most likely subject to large error.

\section{REGIONAL FEEDER CATTLE SUPPLY}

Feeder cattle are supplied from the beef cow herds with the exception of a limited number from dairy herds and from imports of feeder cattle. In this model, we asume that feeder cattle are available in uniform quality at a weight of 650 pounds in the region of the basic breeding cow herd location for domestic feeder cattle, and for the region of importation for foreign feeder cattle. No allowance is made for cattle from dairy herds.

An estimate was made of the total feeder cattle placed in feedlots in the United States for the year beginning October, 1957. Estimated imports of feeder animals were subtracted from this total giving the number of feeder cattle provided by domestic beef herds. This number was allocated among regions in proportion to the number of 
TABLE 6

Estimated Feeder Cattle Supply by Regions for 1957-58 Season

(Per thousand head)

\begin{tabular}{|c|c|c|c|c|}
\hline \multirow{2}{*}{ Region } & \multirow{2}{*}{$\begin{array}{l}\text { January } 1,1957 \\
\text { other cows and } \\
\text { heifers two years } \\
\text { old and over* }\end{array}$} & \multicolumn{3}{|c|}{ Estimated supply of feeder cattle } \\
\hline & & Produced $\dagger$ & Imported & Total \\
\hline $1 \ldots \ldots \ldots \ldots \ldots \ldots \ldots \ldots \ldots \ldots$ & 740 & 322 & & 322 \\
\hline 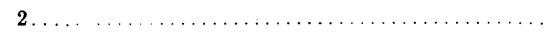 & 762 & 332 & & 332 \\
\hline 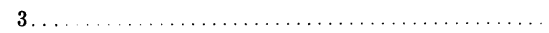 & 104 & 45 & & 45 \\
\hline 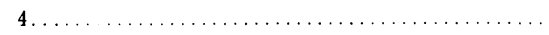 & 303 & 132 & & 132 \\
\hline 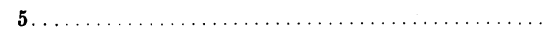 & 623 & 271 & & 271 \\
\hline $\mathbf{6}$ & 389 & 170 & & 170 \\
\hline 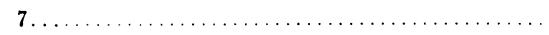 & 1,638 & 713 & $305 \ddagger$ & 1,018 \\
\hline 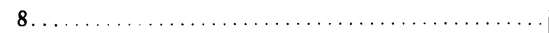 & 685 & 298 & & 298 \\
\hline $9 \ldots \ldots \ldots \ldots \ldots \ldots \ldots$ & 593 & 258 & & 258 \\
\hline 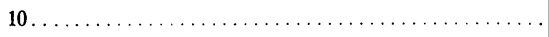 & 1,824 & 795 & & 795 \\
\hline $11 \ldots \ldots \ldots \ldots \ldots \ldots \ldots$ & 2,455 & 1,069 & & 1,069 \\
\hline $12 \ldots \ldots \ldots \ldots \ldots \ldots \ldots \ldots \ldots$ & 4,930 & 2,147 & $238 \S$ & 2,385 \\
\hline $13 \ldots \ldots \ldots \ldots \ldots \ldots \ldots \ldots$ & 397 & 173 & & 173 \\
\hline $14 \ldots \ldots \ldots \ldots \ldots \ldots \ldots$ & 2,590 & 1,128 & & 1,128 \\
\hline $15 \ldots \ldots \ldots \ldots \ldots \ldots \ldots$ & 2,924 & 1,273 & & 1,273 \\
\hline $16 \ldots$ & 697 & 304 & & 304 \\
\hline $17 \ldots$ & 815 & 355 & & 355 \\
\hline $18 \ldots \ldots \ldots \ldots$ & 203 & 88 & & 88 \\
\hline $19 \ldots \ldots \ldots \ldots \ldots$ & 1,240 & 540 & & 540 \\
\hline $20 \ldots \ldots \ldots \ldots \ldots \ldots$ & 842 & 367 & & 367 \\
\hline 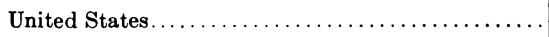 & 24,754 & 10,780 & 543 & 11,323 \\
\hline
\end{tabular}

* Source: U. S. Department of Agriculture, 1958.

† Estimated by applying a factor of .4355 to the January 1 number of "other cows and heifers two years old and over." For derivation of factor, see text.

$\ddagger$ Represents 50 per cent of the 610,697 head of cattle, weighing over 200 pounds imported from Canada during October 1957 -September 1958 as reported in U. S. Bureau of the Census, 1959 B.

\&epresents 50 per cent of the 475,467 head of cattle weighing over 200 pounds imported from Mexico during October 1957-September 1958 as reported in U. S. Bureau of the Census, 1959 B.

"other cows and heifers two years old and over" on January 1, 1957. The method of deriving these estimates is given below.

Data on quarterly feeder placements are available for only thirteen states for the 1957-58 year (see table 5). An estimate of United States placements may be made by expansion of the number of cattle on feed January 1, 1958, using the relationship between these variables which existed for the thirteen states for the years beginning October, 1955-57 and for a 21-state coverage for the year 1958-59. Placements averaged 193 per cent of cattle on feed on January 1 for these four years based on unrevised estimates and 190 per cent based on data shown in table 5. The estimates are based on the unrevised data. The unrevised estimate of the number of cattle on feed in 26 reporting states equalled $5,898,000$ head on January 1, 1958. An estimate of placements equals 11,323,000 head, obtained by multiplying the number on feed January 1, 1958 by the factor of 193 per cent derived above. Of this number 70 per cent are assumed to be steers and 30 per cent heifers.

A considerable number of cattle are imported from both Canada and Mexico. Imports other than for dairy purposes are reported by weight groups which do not provide an easy criterion for estimation of the feeder cattle component. An arbitrary procedure was adopted; namely, to assume that one-half of the cattle weighing over 200 pounds are feeder animals. As shown in table 6, imports of Canadian cattle are allocated to region 7 and imports of Mexican cattle are allocated to region 12 . 
Domestic production of feeder cattle for feedlot feeding is taken as the difference between total placements of 11,323,000 and imports of 543,000 , or 10 ,780,000 head. This number was allocated among regions in proportion to the January 1, 1957 number of cows and heifers, two years old and over, not kept for milk. Feeder production thus represents 43.55 per cent of the inventory number for all regions. The limitations of the approach are readily apparent, but should provide the relative importance of regions as to sources of feeder animals.

\section{THE PRODUCTION PROCESS}

\section{Feed Conversion}

Beef cattle may be fattened on a variety of feeds. The model is set up to handle feeds in the two broad classes of roughages and concentrates, assuming that various feeds within the two categories are perfect substitutes on a net energy basis. The net energy values used are valid only within limits for some feeds. For example, the net energy value used for molasses beet pulp involves the restriction that it not be more than onehalf the concentrate fed. In no region is the supply of beet pulp so large that such a restriction creates a problem.

The situation with respect to protein feeds is not so simple. The net energy values assigned to high protein feeds reflect their contribution providing that the requirement for protein as such is filled. It does not reflect the true marginal productivity of high protein feeds added to a ration deficient in protein. The total United States supply of high protein feeds is small enough that prices reflect a higher marginal productivity for such feed than their value as a source of energy. The particular approach taken here assumes that the protein requirement is filled, and inasmuch as high protein feed prices are higher than the concentrate group, it involves a distortion considered to be of minor significance.

Similarly, the feed substitution used assumes adequate provision for mineral feeds. Mineral feeds, being a rather standard item and a very small portion of the feed costs, are included in the category of nonfeed costs.

It is necessary to estimate the inputoutput relationships for beef in the several regions in order to specify the production activities in the linear program. The production activities represent points on a production surface.

The quantity of inputs of feeder cattle, concentrates, and roughage required to produce 1,000 pounds of beef were developed for each of the nine feeding activities in the 20 regions. We wished to specify weight gains by feeder cattle as related to the level of feeding, the roughage-concentrate ratio, and regional differences in feed conversion efficiency if such existed. Since previous studies were not consistent with these aims, a functional relation was developed using State Agricultural Experiment Station data for recent years, including some 156 lots of cattle. (Sources listed in Appendix B). The functional form selected is a transcendental function linear in logarithms. The relation is as follows: ${ }^{12}$

${ }^{12} R^{2}$ value equals 0.884 . The $t$-ratios are as follows:

$b_{1}:-7.37, b_{3}: 12.81, b_{5}: 2.00, b_{7}:-0.24$,

$b_{2}: 30.33, b_{4}: 4.09, b_{6}:-3.92, b_{8}: 1.26$.

The $\log$ of $b_{9}$ was calculated from the identity $\sum_{i=4}^{9} \log b_{i}=0$ and no $t$ - value is available.

States included in each region are as follows (states from which experimental data were obtained are italicized and the number of lots for each region is shown in parentheses):

$X_{4}$ : Wash., Oreg., Ida., Mont., Wyo., N. Dak., S. Dak. (23)

$X_{5}$ : Calif., Nev. (19)

$X_{6}$ : Utah, Colo., Neb., Kan. (27)

$\mathrm{X}_{7}$ : Ariz., N. Mex., Okla., Texas (20)

(Footnote continued on next page) 


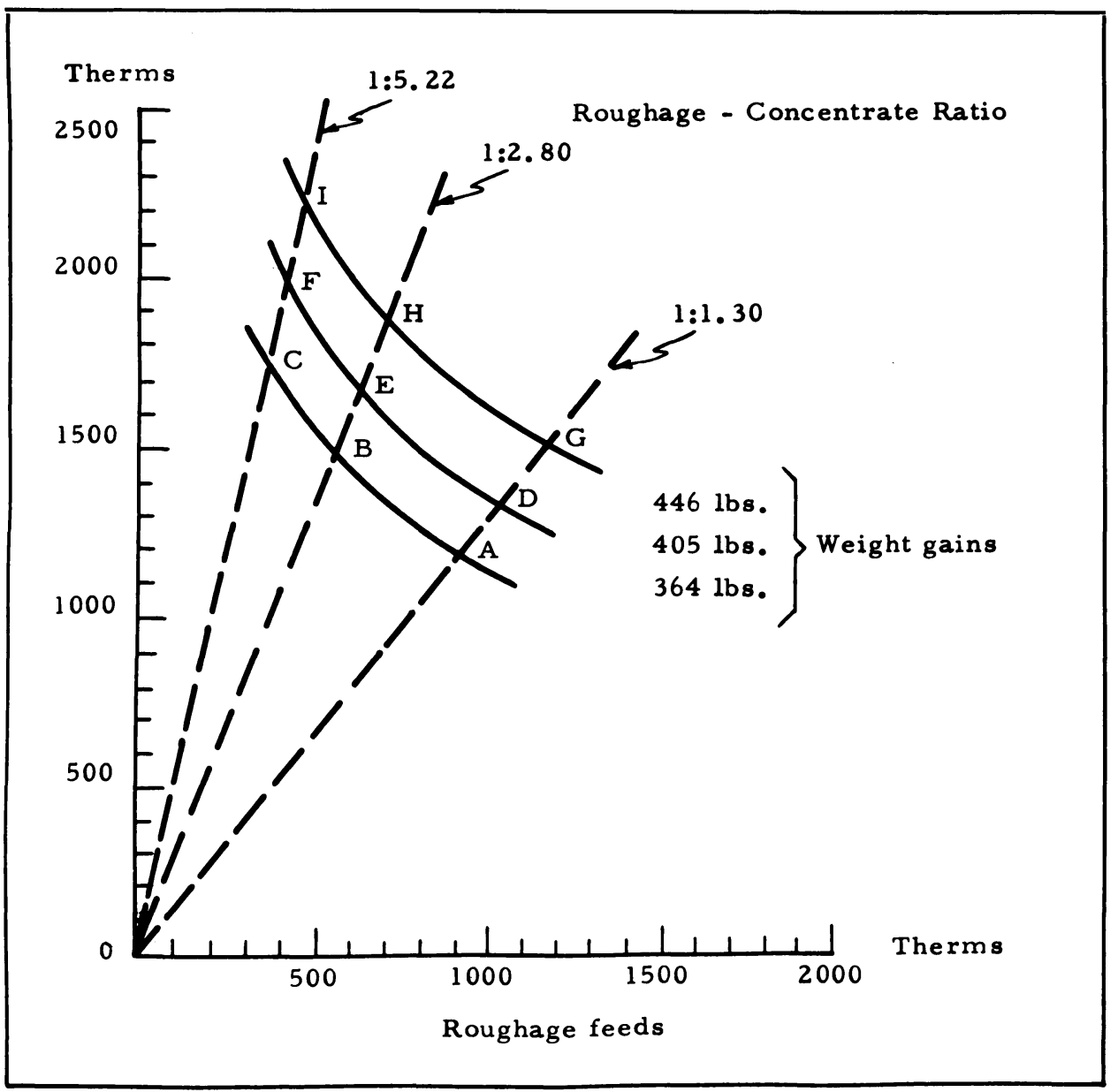

Fig. 4. Relationship among feeding processes for weight gain of a 650-pound feeder animal.

$Y_{i}=18.27 X_{1}^{-.4170} X_{2}^{.5760} X_{3}^{.2372} 1.10^{x} 4$ $1.06{ }^{x} 5.92^{x} 6.99^{x} 71.03^{x} 8.91^{x} 9$ where $Y_{i}=$ total gain in pounds $X_{1}=$ initial weight of feeder cattle (pounds)

$X_{2}=$ net energy value of concentrates fed (therms)

$X_{3}=$ net energy value of roughages fed (therms)

$X_{4}, \ldots, X_{9}$ identify areas:

$X_{i}=1, X_{j} \neq i=0$.

Area differences in feed conversion are estimated as a simple multiplicative effect; therefore it is convenient to define a basic set of production activities, calculated at the average level, that may be easily modified for regional differences. We assume that the initial weight of feeder cattle is 650 pounds, and we may then simplify the previous function to include the effect of initial weight in the constant term, as follows:

$$
\begin{aligned}
& \log Y=0.0875+0.5760 \\
& \log X_{2}+0.2372 \log X_{3} .
\end{aligned}
$$

$X_{8}$ : Minn., Wisc., Iowa, Ill., Mo., Mich., Ind., Ohio, New England, N.Y., Penn., N.J., Md., Del. (33)

$X_{9}$ : Ark., La., Miss., Ala., Ga., Fla., N.C., S.C.,

Tenn., W. Va., Va., Ky. (34) 


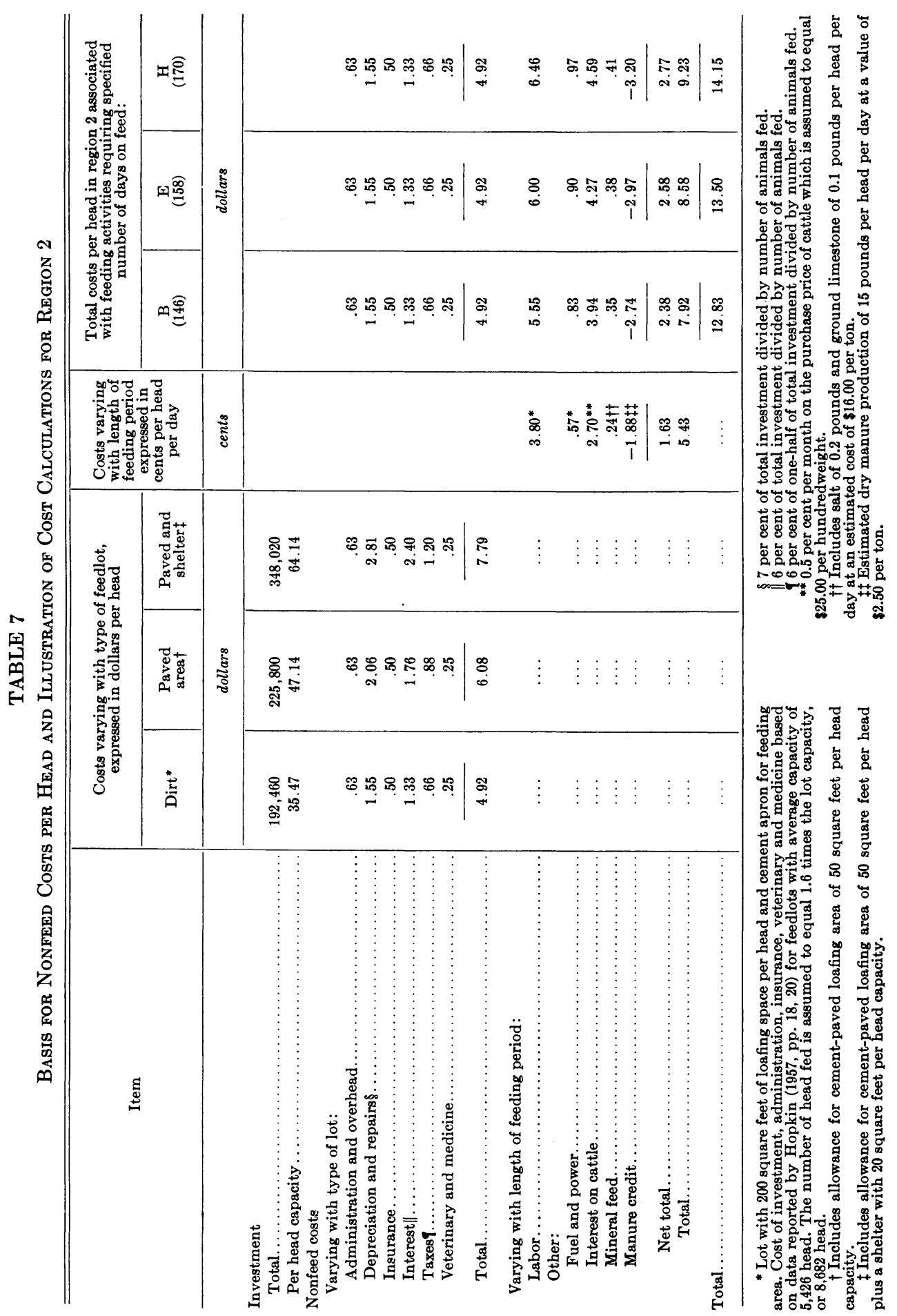


The base ration is established using average values for concentrate and roughage availability for cattle feeding in 1957-58 of 1,697 and 607 therms, respectively. This combination yields 405 pounds of gain per steer and is shown as point $\mathrm{E}$ in figure 4 . The feed requirements were computed using 80 and 120 per cent of the above concentrate requirement to obtain points $\mathrm{D}$ and $\mathrm{F}$ on the 405 pound isoquant. This procedure was repeated for gains of 364 and 446 pounds, giving feed requirements for feeding activities $\mathrm{A}, \mathrm{B}, \mathrm{C}$, and $\mathrm{G}, \mathrm{H}, \mathrm{I}$.

This procedure gives nine basic beefproducing activities, which were then standardized to a production unit of 1,000 pounds of carcass beef. A uniform dressing percentage of 57 per cent is used. An allowance for 3 per cent intransit shrinkage is made in all production activities. ${ }^{13}$ Also a death loss of 0.5 per cent is assumed for cattle on feed with an appropriate adjustment made in the production coefficient. ${ }^{14}$ The production coefficients are given in appendix table C. Differences in time on feed among the various production activities are allowed for in the nonfeed costs associated with each production activity.

\section{Nonfeed Costs}

Nonfeed costs play a role similar to transfer costs in the determination of the location of cattle feeding. Within a region, then, nonfeed costs vary with the feeding activities. Among regions, costs vary with the type of feedlot facility required and with labor costs for that region.

A base-region feedlot is specified and costs then adjusted for varying feeding periods within that region and for cost differences for other regions. The nonfeed costs developed by Hopkin (1957) for a feedlot with capacity of 5,426 head located in California is the basis for estimated costs. It is assumed that the number of cattle fed will equal 1.6 times the feedlot capacity regardless of the length of feeding period. This size of feedlot is such that much of the economies of scale have been achieved. For farm feeding, predominant in many other areas of the country, the assumption is made that the added costs of a complementary farm-feeding operation are approximately equal to those experienced by the large-scale operation.

For a given region, nonfeed costs vary by production activity, depending on the length of time on feed. The time required for a given gain depends upon such factors as initial weight and the type of concentrate-roughage ration fed-the higher the roughage proportion, the more time for a given gain. A function was estimated, using 50 of the 156 lots of cattle used to estimate the production relation, expressing days on feed $(T)$ as a function of initial weight in pounds $\left(X_{1}\right)$, net energy in therms of concentrates fed $\left(X_{2}\right)$, and net energy in therms or roughages fed $\left(X_{3}\right)$. This function is as follows:

$T=$

$$
\begin{gathered}
213-0.234 X_{1}+0.0389 X_{2}+0.0519 X_{3} \\
(10.17) \quad(8.28)
\end{gathered}
$$

The coefficient of determination equalled 0.748 . The $t$-ratios of the regression coefficients are indicated in parentheses.

Calculation of nonfeed costs will be illustrated for region 2 for feeding activities $\mathrm{B}, \mathrm{E}$, and $\mathrm{H}$ which require 146 , 158 , and 170 days on feed, respectively. Nonfeed costs are grouped in table 8 as those which vary with the type of feedlot (dirt, paved area, paved, and shelter) and those which vary with the length of feeding period. A dirt lot is

\footnotetext{
${ }^{18}$ Shrinkage should be treated as a transfer cost; however, there exists no means to allow for a reduction in weight during shipping in the model in use. The use of "pencil shrink" biases the results toward the use of longer shipments.

14 Adams (1954) estimates an average death loss of 0.5 per cent for cattle on feed. Assume the average loss to occur at the mid-point of the feeding period. The feeder cattle requirement is increased by 0.5 per cent and the feed requirement by 0.25 per cent for a given output.
} 


\section{TABLE 8}

Regional Farm Wage Rates, Type of Feedlot Facility, and Nonfeed Costs Associated with Feeding Activity B

(Index Numbers, California Equals 100)

\begin{tabular}{|c|c|c|c|}
\hline Region & $\begin{array}{l}\text { Farm } \\
\text { wage } \\
\text { rates* }\end{array}$ & $\begin{array}{l}\text { Type of } \\
\text { feedlot } \\
\text { facility } \dagger\end{array}$ & $\begin{array}{l}\text { Nonfeed costs } \\
\text { associated with } \\
\text { activity B }\end{array}$ \\
\hline \multicolumn{4}{|l|}{ Pacific } \\
\hline $1 \ldots$ & 104 & D & 101.7 \\
\hline $2 \ldots \ldots$ & 100 & D & 100.0 \\
\hline $3 \ldots$ & 100 & D & 100.0 \\
\hline \multicolumn{4}{|l|}{ Mountain } \\
\hline $4 \ldots \ldots$ & 82 & D & 92.2 \\
\hline $\mathbf{5} \ldots \ldots$ & 84 & D & 93.1 \\
\hline $6 \ldots \ldots \ldots \ldots$ & 76 & D & 89.6 \\
\hline $7 \ldots \ldots \ldots \ldots$ & 77 & D & 90.1 \\
\hline $8 \ldots \ldots$ & 74 & D & 88.8 \\
\hline $9 \ldots \ldots$ & 59 & D & 82.3 \\
\hline \multicolumn{4}{|l|}{ Northern Plains } \\
\hline $10 \ldots \ldots \ldots \ldots$ & 74 & D & 88.8 \\
\hline $11 \ldots \ldots$ & 77 & D & 90.1 \\
\hline \multicolumn{4}{|l|}{ Southern Plains } \\
\hline $12 \ldots \ldots \ldots \ldots$ & 68 & D & 86.2 \\
\hline \multicolumn{4}{|l|}{ Corn Belt and Lake States } \\
\hline $13 \ldots \ldots \ldots \ldots \ldots \ldots$ & 75 & $P+S$ & 111.5 \\
\hline $14 \ldots \ldots \ldots \ldots \ldots \ldots \ldots$ & 72 & $P+S$ & 110.3 \\
\hline $16 \ldots \ldots \ldots \ldots \ldots \ldots$ & 70 & $P+S$ & 109.4 \\
\hline \multicolumn{4}{|l|}{ Northeast } \\
\hline $18 \ldots$ & 82 & $P+S$ & 114.6 \\
\hline \multicolumn{4}{|l|}{ South (excluding region 12) } \\
\hline $15 \ldots \ldots \ldots \ldots \ldots \ldots \ldots$ & 47 & $\mathbf{P}$ & 86.1 \\
\hline $17 \ldots$ & 50 & $\mathbf{P}$ & 87.4 \\
\hline $19 \ldots$ & 48 & $\mathbf{P}$ & 86.6 \\
\hline 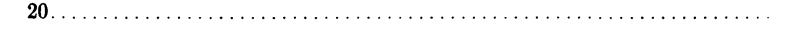 & 58 & $\mathbf{P}$ & 90.9 \\
\hline
\end{tabular}

${ }^{*} \mathrm{U}$. S. Agricultural Marketing Service, $1959 \mathrm{~A}$.
+ For relative costs see table $7 . \mathrm{D}=$ dirt, $\mathrm{P}=$ paved area, $\mathrm{P}+\mathrm{S}=$ paved area plus shelter.

assumed applicable for California feedlot conditions. The cost for items which vary only with type of lot equals $\$ 4.92$ per head and is used for all three feeding activities. Other costs such as labor, fuel and power, etc., vary with length of feeding period. Standard costs per head per day are multiplied by the relevant number of days on feed to obtain the cost per head associated with these nonfeed items. As indicated in table 7, total nonfeed costs increase from a level of $\$ 12.83$ per head for activity B with a feeding period of 146 days to $\$ 14.15$ per head for activity $\mathrm{H}$ with a feeding period of 170 days. Similar cost data are shown in appendix table $\mathrm{D}$ for the other six feeding activities for region 2.

For other regions, nonfeed costs vary with type of feedlot facility and with wage costs, with other costs assumed to be constant. Table 8 indicates the regional index of wage rates used to adjust costs, the feedlot facility specified for each region, and the total nonfeed cost index for a particular feeding activity (B). The actual costs used in the analysis for all regions are shown in appendix table $\mathrm{D}$.

\section{TRANSFER COST FUNCTIONS}

Transportation costs are a major determinant of the location of cattle feeding. Although it would be desirable to use actual point-to-point rates, the data problem precluded this approach. ${ }^{15}$ For interregional shipments, rail rates were developed from the ICC 1 per cent way-

${ }^{15}$ Truck and rail data for 20 regions would require 380 rates each for meat, slaughter cattle, feeder cattle, concentrates, and hay. 
bill sample data. ${ }^{16}$ Equations are shown below for the fitted functions and for these functions adjusted for the units of measure used in the analysis.

\section{Unadjusted Cost Functions}

Rate functions were fitted by least squares to data for shipments of meat, cattle, corn, and hay of the following type:

$$
R=a+b_{1} M+b_{2} M^{1 / 2}
$$

where $R=$ rate per unit

$$
\mathrm{M}=\text { short-line rail mileage. }{ }^{17}
$$

The regression analyses are indicated below with the rate expressed in cents per hundred pounds. The $t$-ratios for the regression coefficients are indicated in parentheses and the coefficient of determination is given for each equation. liveweight equivalent of 1,000 pounds of carcass beef. The adjusted rates for meat and slaughter cattle are as follows where $\mathrm{R}$ equals dollars per unit:

$$
\begin{aligned}
& \text { Meat } \\
& \quad R=.5921+.009584 M+.248552 M^{1 / 2} \\
& \text { Slaughter cattle } \\
& \quad R=1.890+.011375 M+.309538 M^{1 / 2}
\end{aligned}
$$

It is apparent that in no case will the rate for slaughter cattle be lower than for an equivalent amount of meat according to the above estimates. Therefore, the meat rate applies for all shipments, assuming that slaughter takes place in the feeding area. Interregional meat shipment costs per 1,000 pounds of carcass beef are shown in table 9 .

Intraregional meat shipment distances and transfer costs are considered

$$
\begin{aligned}
& \text { Meat } r=5.921+0.095836 M+2.485520 M^{1 / 2} \\
& R^{2}=.89 \\
& \text { Cattle } r=10.774+0.064851 M+1.764759 M^{1 / 2} \\
& R^{2}=.89 \\
& \text { Corn } r=4.692+0.035548 M+0.604269 M^{1 / 2} \\
& R^{2}=.59 \\
& \text { Hay } r=0.0+0.047341 M+2.238693 M^{1 / 2} \\
& R^{2}=.86
\end{aligned}
$$

The equation for hay was modified to force the intercept value to equal zero since the original equation gave a negative value which was rejected on an a priori basis.

\section{Adjusted Cost Functions}

The cost functions derived above were adjusted to the units of measure used in the analysis, and the rate expressed in dollars per unit. The unit of measurement for meat is 1,000 pounds and that for slaughter cattle 1,754 pounds, or the

to be equal in all regions, as discussed on page 340 . The cost per 1,000-pound unit of meat is given in table 10 .

For the intermediate products of feeder cattle, feed concentrates, and hay, transfer costs used in the model are net transfer costs, or interregional rail rates less within-region truck costs. Thus, cost functions for these items are adjusted by (1) converting to the unit of measurement used in the analysis and (2) deducting the within-region truck costs from the constant or inter-

\footnotetext{
${ }^{16}$ Carload Waybill Analysis, State-to-State Distribution of Animals and Products Traffic and Revenue, One Percent Sample of Terminations in the Year 1958 (1959), and Carload Waybill Analysis, State-to-State Distribution of Products of Agriculture, 1958 (1959).

${ }^{17}$ Short-line rail mileages were developed from Commercial Atlas and Marketing Guide, 1960 (1960) ; Local and Joint Distance Table No. 420-D; and the Official Guide of the Railways and Steam Navigation Lines of the United States.
} 


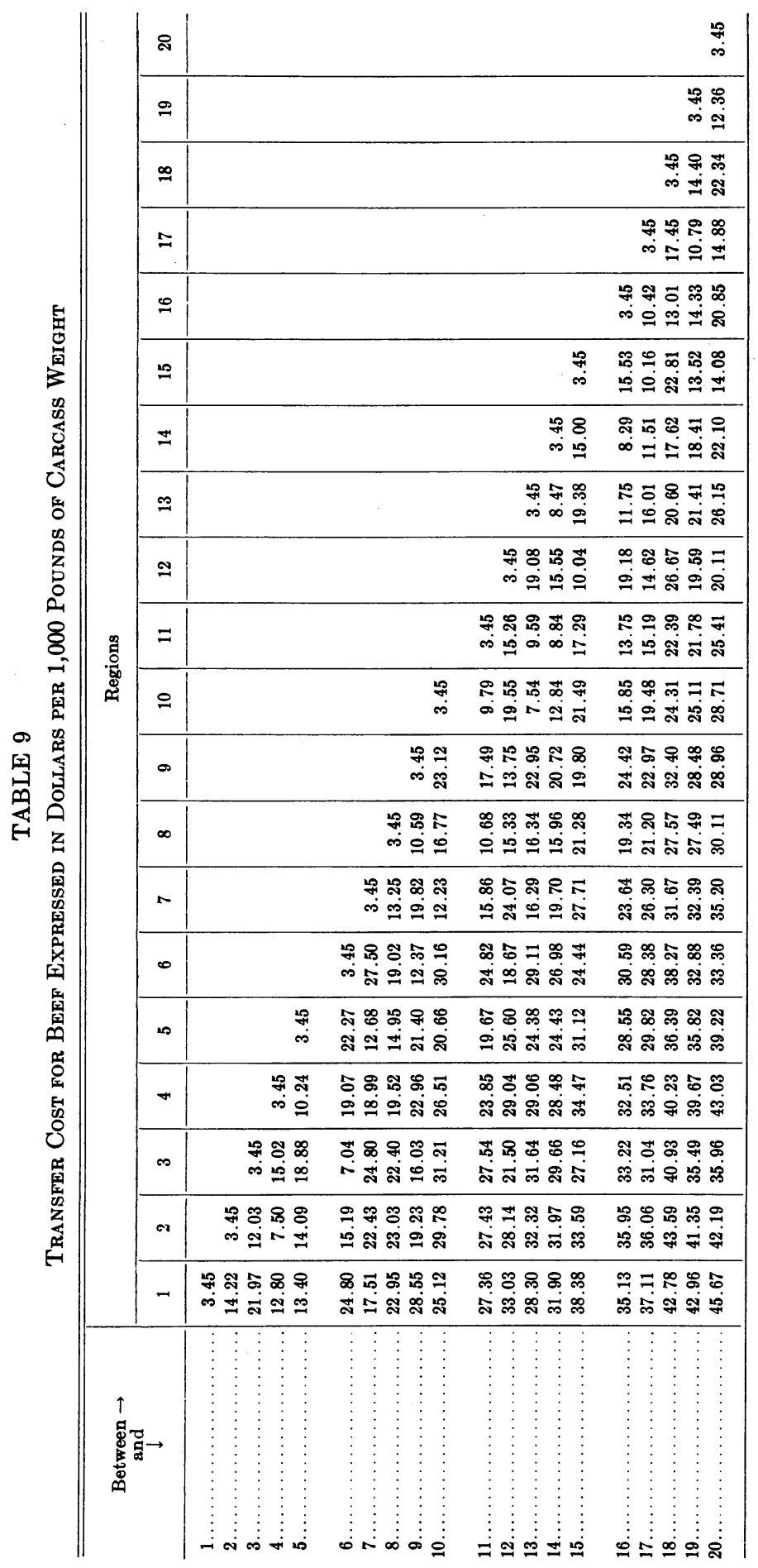


TABLE 10

Intraregional Transfer Costs by Commodity for Specified Distances Shipped

\begin{tabular}{|c|c|c|c|c|}
\hline Commodity & Miles & $\frac{\begin{array}{c}\text { Rate per } \\
100 \text { pounds* }\end{array}}{\text { dollars }}$ & \multicolumn{2}{|c|}{ Adjusted unit cost } \\
\hline Carcass beef. & 50 & 0.345 & 1,000 pounds & $3.45 \dagger$ \\
\hline Slaughtered cattle. & 50 & 0.220 & 1,754 pounds & 3.86 \\
\hline Нау........ & 25 & 0.160 & 1,000 therms & 3.94 \\
\hline
\end{tabular}

* Minimum rates for moves within the State of California as reported by the Public Utilities Commission of the State of California, 1959.

$\dagger$ A lower rate was used for Region 6 (Arizona) equal to $\$ 3.38$ per 1,000 pounds of carcass beef.

cept value of the adjusted function. The unit of measurement for feeder cattle is a 650-pound animal and for feeds 1,000 therms of net energy. Concentrate feeds are assumed to be shipped as corn which contains 80.1 therms per 100 pounds, and roughage feeds are assumed to be shipped as hay which contains 40.6 therms per 100 pounds. The adjusted cost functions are as follows:

$$
\begin{aligned}
& \text { Feeder cattle } \\
& \quad R=-0.730+.004215 M+.114709 M^{1 / 2} \\
& \text { Corn } \\
& \quad R=-0.914+.004436 M+.075413 M^{1 / 2} \\
& H a y \\
& \quad R=-3.94+.011660 M+.551390 M^{1 / 2}
\end{aligned}
$$

The net transfer cost for shipment among regions is given for feeder cattle in table 11, for corn in table 12, and for hay in table 13.

\section{DEMAND FOR BEEF}

The demand for beef in this model relates to the wholesale level. No account is taken of the supplies or prices of other meats and in general no distinction is made between fed and nonfed beef. Neither price nor quantity data are considered adequate to fit statistical demand functions for each region. The procedure adopted was to use demand elasticities for the United States and adjust regional estimates of consumption and prices based on dif- ferences in consumer income and population levels.

Wallace and Judge (1958) have estimated the price and income elasticity of demand for beef at retail as -0.86 and 0.59 , respectively. From these data, a linear approximation of demand for the year 1958 may be derived. The general linear equation is:

$$
Q=a+b_{1} P+b_{2} I
$$

where

$$
Q=\text { per capita consumption of }
$$
beef in the United States.

$a=$ constant

$P=$ average retail price of beef in the United States in cents per pound.

$I=$ per capita disposable personal income in the United States.

Working from the price elasticity formula,

$$
e_{p}=\frac{\partial Q}{\partial P}-\frac{\bar{P}}{\bar{Q}}
$$

and since the equation is linear,

or,

$$
b_{1}=\frac{\partial Q}{\partial P}
$$

$$
b_{1}=e_{p} \frac{\bar{Q}}{\bar{P}}
$$

and similarly, for the income effect,

$$
b_{2}=e_{y} \frac{\bar{Q}}{\bar{I}}
$$




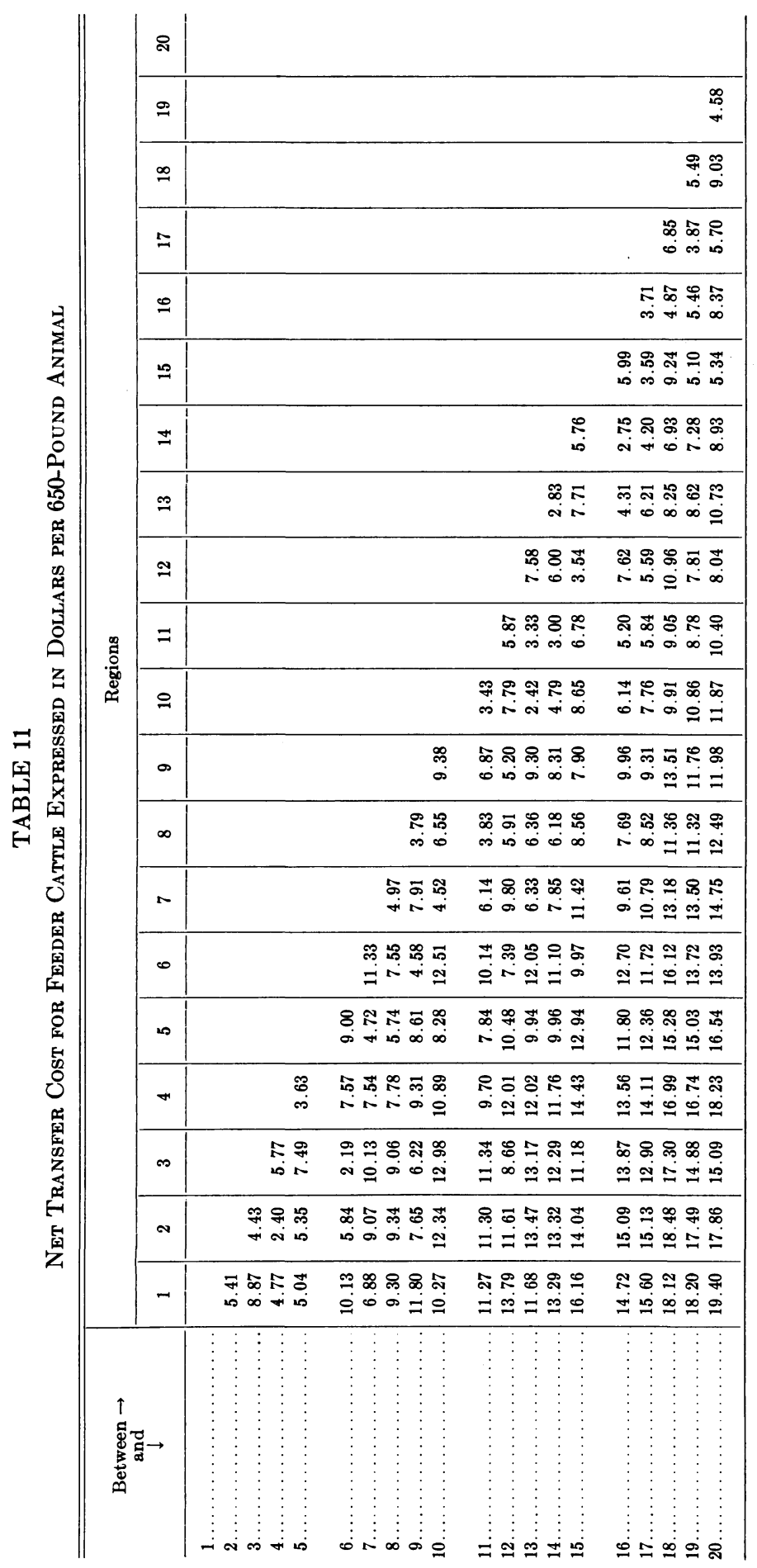




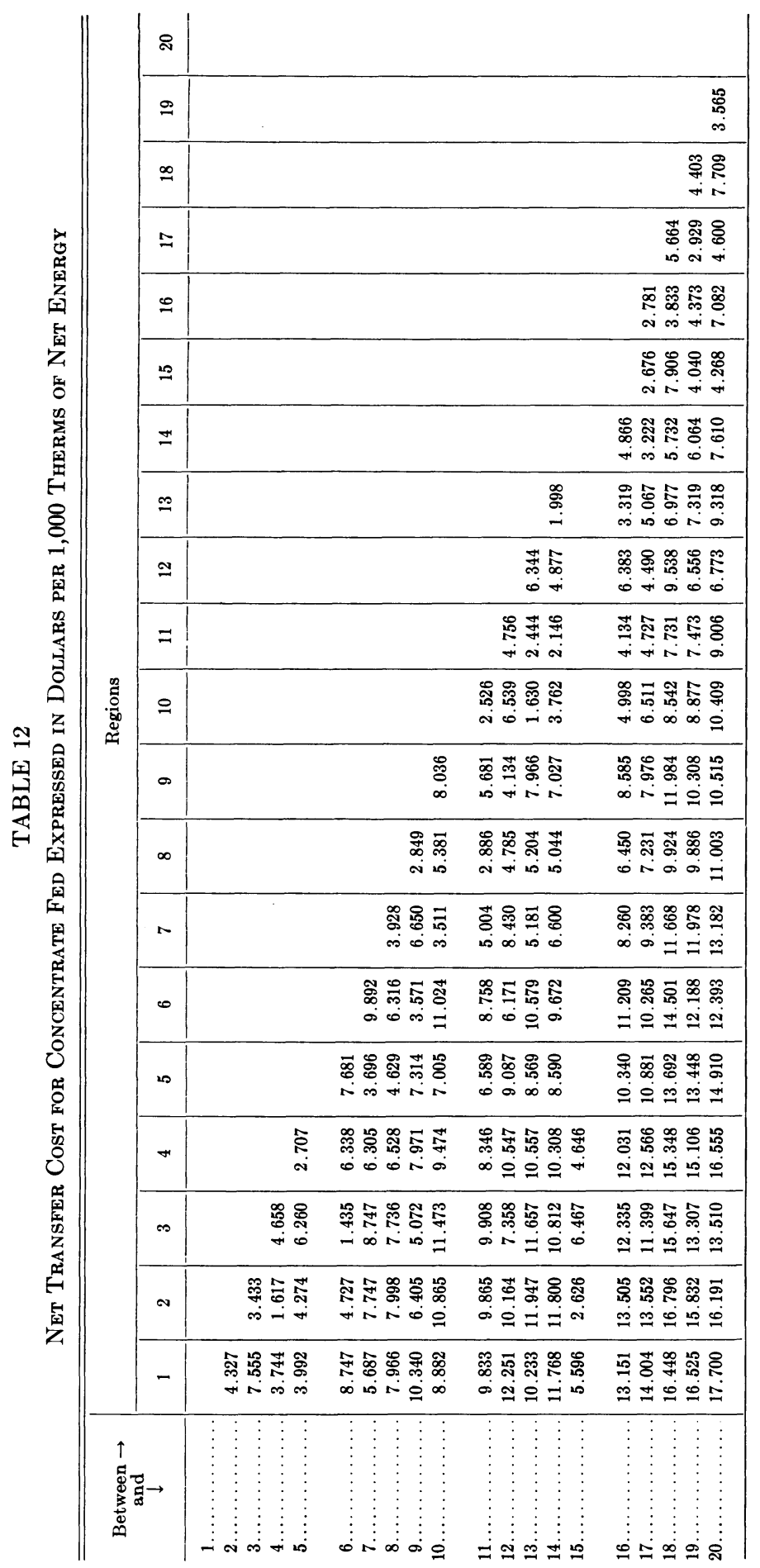




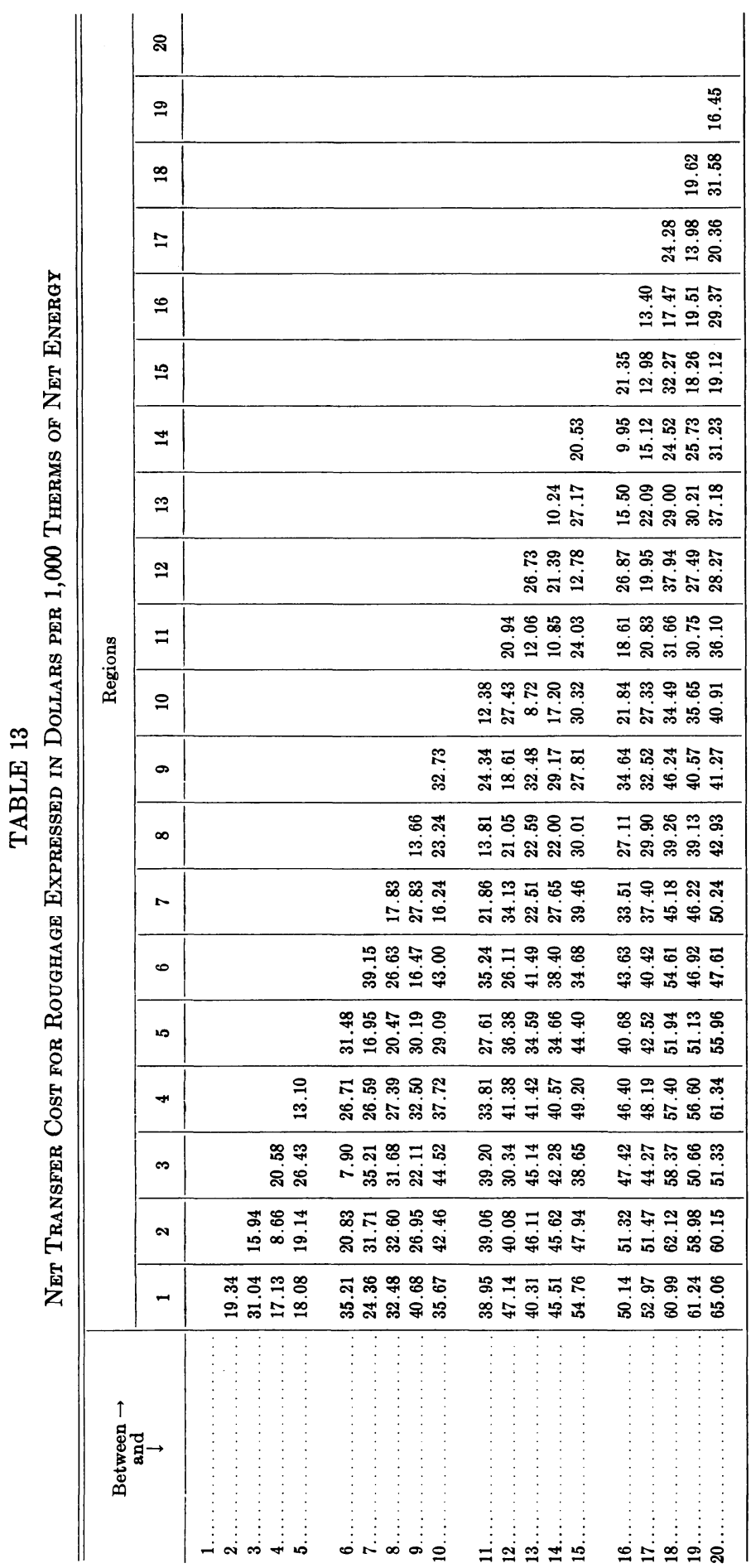


TABLE 14

1958 Population, per Capita Disposable Income, and Calculated Coefficients of Regional Demand Functions

\begin{tabular}{|c|c|c|c|c|}
\hline \multirow{2}{*}{ Region } & \multirow{2}{*}{$\begin{array}{c}N_{i}^{*} \\
\text { Population }\end{array}$} & \multirow{2}{*}{$\underset{\substack{\text { Disposable } \\
\text { personal } \\
\text { income }}}{\stackrel{I_{i} \dagger}{ }}$} & \multicolumn{2}{|c|}{ Coefficients of regional demand function } \\
\hline & & & Intercept $a_{i}^{\prime}$ & Slope $b_{i}{ }^{\prime}$ \\
\hline & thousand & dollars & & \\
\hline $1 \ldots \ldots \ldots \ldots \ldots \ldots \ldots \ldots$ & 4,516 & 1,864 & 590.1895 & $-\quad 4.824732$ \\
\hline $2 \ldots \ldots \ldots \ldots$ & 5,854 & 2,200 & 816.2267 & -6.254203 \\
\hline $\mathbf{3} \ldots \ldots \ldots \ldots$ & 8,430 & 2,200 & $1,175.4000$ & -9.006309 \\
\hline $4 \ldots$ & 272 & 2,272 & 38.4347 & $-\quad 0.290595$ \\
\hline $\mathbf{5} \ldots \ldots \ldots \ldots$ & 1,510 & 1,542 & 184.6892 & -1.613230 \\
\hline $6 \ldots \ldots \ldots$ & 1,175 & 1,670 & 147.6282 & $-\quad 1.255328$ \\
\hline $7 \ldots \ldots \ldots$ & 990 & 1,803 & 127.8104 & -1.057680 \\
\hline $8 \ldots$ & 1,655 & 1,795 & 213.3184 & $-\quad 1.768142$ \\
\hline $9 .$. & 855 & 1,542 & 104.5757 & $-\quad 0.913451$ \\
\hline $10 \ldots \ldots \ldots$ & 1,322 & 1,466 & 159.0807 & $-\quad 1.412377$ \\
\hline $11 \ldots \ldots \ldots$ & 3,548 & 1,748 & 452.9748 & $-\quad 3.790555$ \\
\hline $12 \ldots \ldots \ldots \ldots$ & 11,576 & 1,609 & $1,436.0487$ & -12.367382 \\
\hline $13 \ldots \ldots \ldots$ & 7,277 & 1,738 & 927.1646 & -7.774485 \\
\hline $14 \ldots \ldots \ldots$ & 16,998 & 2,016 & $2,288.6666$ & -18.160051 \\
\hline $15 \ldots \ldots \ldots \ldots \ldots$ & 10,179 & 1,167 & $1,145.6872$ & -10.874877 \\
\hline $16 \ldots \ldots \ldots$ & 21,928 & 1,897 & $2,884.5658$ & -23.427086 \\
\hline $17 \ldots \ldots \ldots \ldots \ldots \ldots \ldots \ldots \ldots$ & 8,520 & 1,304 & 989.3294 & -9.102461 \\
\hline $18 \ldots \ldots \ldots \ldots$ & 47,561 & 2,112 & $6,522.5639$ & -50.812460 \\
\hline 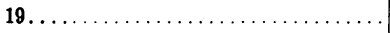 & 14,552 & 1,314 & $1,693.5421$ & -15.546833 \\
\hline 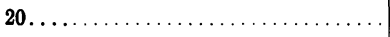 & 4,515 & 1,660 & 566.0947 & -4.823663 \\
\hline United States... & 173,233 & 1,825 & $22,463.9913$ & -185.075900 \\
\hline
\end{tabular}

* U. S. Bureau of the Census, 1959 A.

$\dagger$ U. S. Department of Commerce, 1960.

and the constant becomes,

$$
a=\bar{Q}-b_{1} \bar{P}-b_{2} I
$$

where the bar indicates the average value for 1958 .

In the original analysis by Wallace and Judge, all price and income data were deflated by the consumer price index. Since this study involves but one year, the variables are expressed in 1958 dollars. The 1958 average per capita beef consumption, on a carcass weight basis, was 80.5 pounds; the 1958 average retail price of beef (carcass weight) was 64.8 cents per pound; and the average per capita disposable personal income was $\$ 1,825.50$. The estimate of the retail demand function is:

$$
Q=102.234-1.068364 P+0.026018 I
$$

The wholesale demand for beef is derived from the retail demand by reduc- ing the constant term by the quantity effect associated with the 1958 average retail-wholesale price spread of 18.76 cents per pound. (U. S. Marketing Service, 1960, p. 17). The derived wholesale demand for beef is estimated as:

$$
Q=82.191-1.068364 P+0.026018 I
$$

Regional demand functions are then derived from the above formula. The per capita demand for beef in region $i$ may be expressed as:

$$
Q_{i}=a+b_{1} P_{i}+b_{2} I_{i}
$$

Since income is taken as given for the season involved, the income effect is included in the constant term: or,

$$
a_{i}=a+b_{2} I_{i}
$$

and the per capita demand function written as:

$$
Q_{i}=a_{i}+b_{1} P_{i}
$$


In terms of total quantity, we multiply through by regional population, or

$$
N_{i} Q_{i}=N_{i} a_{i}+N_{i} b_{1} P_{i}
$$

where

$$
\begin{aligned}
& N_{i}=\text { population of region } i \text { on } \\
& \text { July } 1,1958 \text {. }
\end{aligned}
$$

This may be rewritten as:

$$
Q_{i}^{\prime}=a_{i}^{\prime}+b_{i} P
$$

where

$$
\begin{aligned}
a_{i}^{\prime} & =a_{i} N_{i} \\
b_{i}^{\prime} & =b_{1} N_{i}
\end{aligned}
$$

The estimates of $a^{\prime}{ }_{i}$ and $b^{\prime}{ }_{i}$ are shown in table 14 . The values of $N_{i}$ relate to the population estimate for July 1, 1958. The value of $I_{i}$ relates to disposable personal income. Disposable personal income is not reported by states for the year 1958 and was estimated based on the relation between personal and disposable personal income reported at the national level and the reported data by states on personal income. Regional levels of disposable personal income represent weighted averages of state per capita income using the July 1, 1958 population data as weights.

Summing the total demand over 20 regions, we obtain:

$$
\sum_{i=1}^{20} Q_{i}^{\prime}=\sum_{i=1}^{20} a_{i}^{\prime}+\sum_{i=1}^{20} b_{i}^{\prime} P_{i}
$$

This expression is used in determining the quantity consumed by region for a given set of regional prices. In this model, the values of $P_{i}$ relate to the market wholesale price. In equilibrium, the imputed regional values obtained in the dual solution will equal the regional set of prices. The process of obtaining these equilibrium prices requires revision of the initial set of prices, and the associated quantity consumed, in successive runs of the problem. ${ }^{18}$

\section{REGIONAL SUPPLIES OF BEEF NOT FEEDLOT FINISHED}

The total number of cattle slaughtered in the United States in 1958 equalled 24,396,000 head (U. S. Agric. Marketing Serv., 1959C). Of this number $11,266,000$ are estimated to be marketed from feedlots as shown in table 15; 583,000 from imported slaughterweight animals from Canada and Mex-

18 The procedure used in revising prices and quantities in successive runs of the problem is explained in detail by Judge and Wallace (1959, p. 9-16) for obtaining equilibrium regional price differentials from a base region. The method used here involves absolute prices rather than price differentials but is essentially the same method. The procedure may be outlined as follows:

1. The total amount of beef shipments $\left(\sum_{i=1}^{20} X_{i j}\right)$ is calculated from a previous run.

2. The imputed prices from the previous run are used to calculate the regional consumption of beef $\left(Q^{\prime}{ }_{i}\right)$ using regional demand functions (see table 14). These values are then added, or: $\sum_{i=1}^{20} Q^{\prime}{ }_{i}$

3. Subtract the value obtained in (2) from that obtained in (1). If this value is negative, the next set of prices will have to be revised upward since the amount consumed at these prices is greater than the amount produced plus that available as nonfed beef.

4. The amount of the price correction factor to apply to the imputed prices is obtained by calculating the following correction factor $P_{o}$ :

$$
P_{o}=\frac{(1)-(2)}{\sum_{i=1}^{20} b_{i}} \text { where } b_{i} \text { values are as shown in table } 14 .
$$

5. The revised set of regional prices, equal to the imputed price plus the value of $P_{o}$, are then used to obtain the regional quantities consumed based on the regional demand function. This procedure is repeated until the assumed regional prices are in agreement with the imputed prices obtained in the dual solution. The imputed prices are at feedlot locations and thus will differ from market prices by intraregional transfer costs. 
TABLE 15

Estimated Number of Cattle Marketed in 1958

(Per thousand head)

\begin{tabular}{|c|c|c|c|c|}
\hline \multirow{2}{*}{ Region } & \multirow{2}{*}{$\begin{array}{c}\text { Cattle on feed } \\
\text { January } 1,1958^{*}\end{array}$} & \multicolumn{3}{|c|}{ Marketings } \\
\hline & & Estimated $\dagger$ & Reported* & Adjusted $\ddagger$ \\
\hline 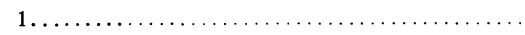 & 139 & 259 & .. & 253 \\
\hline $2 \ldots \ldots \ldots \ldots \ldots \ldots \ldots \ldots \ldots \ldots \ldots \ldots \ldots$ & $\ldots$ & $\ldots$ & $(585) \S$ & 571 \\
\hline 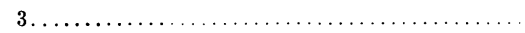 & $\ldots$ & $\ldots$ & $(584) \S$ & 570 \\
\hline $2+3 \ldots \ldots \ldots \ldots \ldots \ldots \ldots \ldots \ldots \ldots \ldots \ldots \ldots \ldots \ldots$ & 405 & $\ldots$ & 1,169 & $\ldots$ \\
\hline 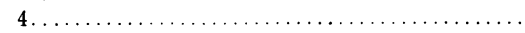 & 28 & 39 & ... & 38 \\
\hline 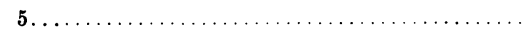 & 164 & 287 & $\cdots$ & 280 \\
\hline $6 \ldots \ldots \ldots \ldots \ldots$ & 190 & $\cdots$ & 410 & 400 \\
\hline $7 \ldots \ldots \ldots \ldots \ldots$ & 113 & 179 & ... & 175 \\
\hline $8 \ldots \ldots \ldots \ldots \ldots \ldots$ & 298 & $\ldots$ & 664 & 648 \\
\hline $9 \ldots \ldots \ldots \ldots \ldots \ldots \ldots \ldots \ldots \ldots \ldots$ & 33 & 69 & $\ldots$ & 68 \\
\hline 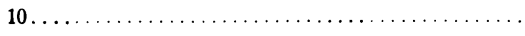 & 364 & 554 & $\ldots$ & 541 \\
\hline $11 \ldots \ldots \ldots \ldots \ldots$ & 714 & $\ldots$ & 1,593 & 1,556 \\
\hline 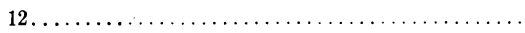 & 163 & $\ldots$ & 410 & 400 \\
\hline 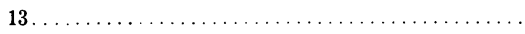 & 482 & 697 & $\ldots$ & 681 \\
\hline $14 \ldots \ldots \ldots \ldots \ldots$ & 2,198 & $\ldots$ & 4,011 & 3,917 \\
\hline $15 \ldots \ldots \ldots \ldots \ldots$ & $\cdots$ & 85 & $\cdots$ & 83 \\
\hline $16 \ldots \ldots \ldots \ldots \ldots$ & 529 & 763 & $\ldots$ & 745 \\
\hline 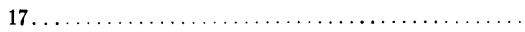 & $\ldots$ & 75 & $\ldots$ & 73 \\
\hline $18 \| \ldots \ldots \ldots \ldots \ldots \ldots \ldots \ldots \ldots \ldots \ldots \ldots$ & 78 & 137 & $\ldots$ & 134 \\
\hline 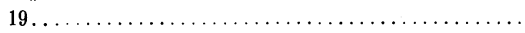 & $\ldots$ & 98 & $\ldots$ & 96 \\
\hline 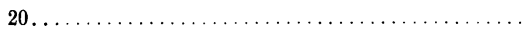 & $\cdots$ & 38 & $\cdots$ & 37 \\
\hline Total.................... & 5,8989 & 3,280 & 8,257 & 11,266 \\
\hline
\end{tabular}

* U. S. Department of Agriculture, 1961.

$\dagger$ For states in which cattle on feed are reported, marketings are based on the percent marketings in 1960 exceeded the number on feed, January 1,1960 . These percentages are as follows: region 1,$186 ;$ region 4,$141 ;$ region 5,$175 ;$ region 7 , 158; region 9, 209; region 10 for North Dakota, 142; region 13 for Wisconsin, 136; region 16 for Michigan, 135 ; region 18 for Pennsylvania, 176. For states in which cattle on feed are not reported for 1958 but are reported for 1960 , marketings equal $82 \%$ of cattle on feed on January 1,1960 . This percentage equals the 26-state total number of cattle on feed on January 1,1958 as compared with January 1,1960 . This probably underestimates numbers marketed in regions $15,17,19,20$.

\pm The sum of estimated plus reported marketings equals $11,537,000$ head as compared with $11,266,000$ for Model I. To allow direct comparison of models in actual marketings, actual marketings were adjusted by a factor of 97.65 percent. \$ Marketings assumed to equal 50 per cent of total California marketings, based on cattle on feed by areas as reported in California Crop and Reporting Service, California Annual Livestock Report, Sacramento, 1959, but within Kern and in California Crop and Reporting Service, California Annual Livestock Report, Sacrame

II Pennsylvania.

I Reported cattle on feed for 26-state total.

ico; and 12,547,000 from other sources. In addition to the live animals, net meat imports into the country equalled 337,925,000 pounds of carcass beef.

It was necessary to employ estimating procedures in obtaining national and regional data on the nonfed beef supplied from various sources. For meat net imports, quantities were allocated to four coastal regions (regions $1,2,3$, and 18) based on data published by U. S. Army Corps of Engineers (1959). For slaughter-weight animal imports, the carcass weight equivalent of animals imported from Canada were allocated to region 7 and those from Mexico were allocated to region 12. These data are shown in table 16.

Estimates were required for beef production from cull dairy cows, dairy heifers, beef cows and heifers, bulls, and other cattle. This was done on a national basis, using a balance sheet method considering cattle inventory numbers on January 1, 1958 and 1959 and total number of cattle slaughtered during 1958. Factors as shown in table 17 were derived for use in applying to regional January 1 inventory numbers as a basis for obtaining regional estimates of nonfed beef. Table 16 shows estimated availability of nonfed beef from all sources. 
TABLE 16

Beef Availability from Sources Other Than Feed Lots by Region, Calendar Year 1958

\begin{tabular}{|c|c|c|c|c|c|}
\hline \multirow{2}{*}{ Region } & \multicolumn{3}{|c|}{ Domestic production } & \multirow{2}{*}{ 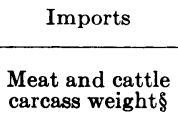 } & \multirow{2}{*}{$\frac{\text { Total }}{\begin{array}{c}\text { Carcass weight } \\
\text { equivalent }\end{array}}$} \\
\hline & Number* & $\begin{array}{l}\text { Total live } \\
\text { weight }\end{array}$ & $\begin{array}{l}\text { Carcass } \\
\text { weight } \ddagger\end{array}$ & & \\
\hline & thousand & \multicolumn{4}{|c|}{ thousand pounds } \\
\hline 1. & 333 & 329,171 & 181,044 & 16,897 & 197,941 \\
\hline $2 \ldots$ & 387 & 382,177 & 210,198 & 57,447 & 267,645 \\
\hline 3. & 93 & 92,106 & 50,658 & 10,137 & 60,795 \\
\hline $4 \ldots$ & 82 & 81,161 & 44,639 & $\ldots \ldots$ & 44,639 \\
\hline $5 \ldots$ & 260 & 256,888 & 141,288 & $\ldots \ldots$ & 141,288 \\
\hline$\cdots$ & 111 & 109,844 & 60,414 & $\ldots \ldots$ & 60,414 \\
\hline $7 \ldots \ldots$ & 463 & 458,891 & 252,390 & 178,585 & 430,975 \\
\hline $8 \ldots$ & 229 & 226,780 & 124,729 & $\ldots \ldots$ & 124,729 \\
\hline $\mathbf{9} \ldots \ldots$ & 166 & 164,515 & 90,483 & $\ldots \ldots$ & 90,483 \\
\hline $10 \ldots \ldots$ & 672 & 664,739 & 365,606 & $\ldots \ldots$ & 365,606 \\
\hline $11 \ldots \ldots \ldots \ldots \ldots \ldots$ & 892 & 883,092 & 485,700 & $\ldots \ldots$ & 485,700 \\
\hline $12 \ldots \ldots \ldots \ldots \ldots \ldots \ldots$ & 1,591 & $1,575,534$ & 866,544 & 140,316 & $1,006,860$ \\
\hline $13 \ldots \ldots \ldots \ldots \ldots \ldots \ldots$ & 1,209 & $1,192,469$ & 655,858 & $\ldots \ldots$ & 655,858 \\
\hline $14 \ldots \ldots \ldots$ & 1,408 & $1,391,810$ & 765,496 & $\ldots \ldots$ & 765,496 \\
\hline $15 \ldots \ldots \ldots$ & 1,229 & $1,215,442$ & 668,494 & $\ldots \ldots$ & 668,494 \\
\hline $16 \ldots$ & 811 & 800,725 & 440,398 & $\ldots \ldots$ & 440,398 \\
\hline $17 \ldots \ldots$ & 613 & 606,911 & 333,802 & $\ldots \ldots$ & 333,802 \\
\hline $18 \ldots \ldots$ & 1,039 & $1,027,007$ & 564,854 & 253,443 & 818,297 \\
\hline $19 \ldots \ldots \ldots$ & 680 & 672,494 & 369,871 & $\ldots \ldots$ & 369,871 \\
\hline $20 \ldots \ldots \ldots$ & 279 & 276,005 & 151,803 & $\ldots \ldots$ & 151,803 \\
\hline United States.... & 12,547 & $12,407,761$ & $6,824,269$ & 656,825 & $7,481,094$ \\
\hline
\end{tabular}

* See text for estimation procedure.

† See table 17 for assumed liveweight of animals by class.

$\$ 55$ per cent of live weight.

$\$$ Meat imports totaling $337,925,000$ pounds were allocated explained in the text as follows: region 1,5 per cent; region 2,17 per cent; region 3,3 per cent; and region 18,75 per cent. The carcass weight equivalent of imported slaughter weight animals was estimated at $\mathbf{1 7 8 , 5 8 5 , 0 0 0}$ pounds from Canada and was allocated to region 7; that from Mexico was estimated at $140,316,000$ pounds and was allocated to region 12 .

TABLE 17

Basis of Estimating Nonfed Beef Available by Region, 1958

\begin{tabular}{|c|c|c|c|c|}
\hline \multirow{2}{*}{ Class } & \multirow{2}{*}{$\begin{array}{l}\text { Estimated } \\
\text { number of } \\
\text { head }\end{array}$} & \multirow{2}{*}{$\begin{array}{l}\text { Estimated } \\
\text { average live } \\
\text { weight }\end{array}$} & \multicolumn{2}{|r|}{ Factor used for regional estimates } \\
\hline & & & Factor & January 1 inventory group \\
\hline & thousand & pounds & per cent & \\
\hline Cull dairy cows $\ldots \ldots \ldots$ & 5,609 & 1,000 & 25.23 & $\begin{array}{l}\text { Cows and heifers, two years old and over kept for } \\
\text { milk }\end{array}$ \\
\hline Cull dairy heifers....... & 495 & 825 & 8.41 & Heifer calves kept for milk \\
\hline Cull beef cows and heifers. & 3,140 & 1,000 & 12.93 & Other cows and heifers two years and over \\
\hline Cull bulls. & 180 & 1,020 & 10.92 & Bulls, one year and over \\
\hline Other cattle. & 3,123 & 982 & 12.86 & Other cows and heifers, two years and over \\
\hline Total. & 12,547 & & & \\
\hline
\end{tabular}




\section{LOCATION MODELS OF BEEF CATTLE FEEDING}

The analysis of the location of beef cattle feeding is based on the model previously described plus three modified versions that differ as to specified regional feeding efficiency, nonfeed costs, and the nature of the demand for beef. All analyses relate to marketings for 1958. These models may be described briefly as follows:

Model I: Supply of intermediate products of feed concentrates, roughage, and feeder cattle in each region is given; production activities relating weight gain to feed input differ among regions with feeding efficiency of that region; transfer functions are specified for the intermediate products and for the product (meat); feedlot nonfeed costs differ among regions depending on construction and wage costs and within a region with each feeding activity; demand for beef relates the total quantity consumed of fed and nonfed beef to price and income of the region.

Model II: Differs from model I in that nonfeed costs are assumed equal among regions for a given feeding activity.

Model III: Differs from model I in that nonfeed costs are assumed equal among regions for a given feeding activity, and that feeding efficiency is equal among regions.

Model IV: Differs from model I in that nonfeed costs are assumed equal among regions for a given feeding activity, and that the consumption of beef for each region consists of the same proportion of fed and nonfed beef.

The linear programming method offers two sources of information, the direct solution and the dual. The direct solution provides the following data:

1. Location of beef cattle feeding and type of feeding activity employed as to weight gain and concentrateroughage ration.
2. Shipment pattern of beef.

3. Shipment pattern of feeder cattle, concentrates and roughage.

4. Equilibrium prices and consumption of beef.

The dual solution provides the following information:

1. The imputed prices of factors consistent with equilibrium flow.

2 . The cost associated with introducing activities not in the optimum solution.

An analysis of the results obtained under the four models are presented next, followed by an evaluation of the approach used in the study of feedlot location.

\section{MODEL I}

The equilibrium pattern of beef production, consumption, and flows of carcass beef, feeder cattle, and feeds are shown in table 18. Beef production is indicated as that produced from feedlots and that available as nonfed beef. The production of fed beef is directly related to the number of cattle marketed by coefficients of the relevant feeding activity. The number of cattle placed on feed is slightly higher than the number marketed to allow for a death loss of one-half of one per cent. The nature of the solution may be illustrated with region 3, for which 423 thousand head of cattle are marketed. The factor requirements per 1,000 pounds of beef produced, as shown in appendix table $\mathrm{C}$, are as follows: feeder cattle, 1.7992; feed concentrates, 2.6688 thousand therms of net energy; and roughage, 0.9548 thousand therms of net energy. The basis for the feeding activities is illustrated in figure 4. To produce 236 million pounds of beef, 425 thousand feeder cattle are required (i.e., 236 multiplied by $1.7992)$. Death loss of 0.5 per cent results in marketings of 423 thousand head. 


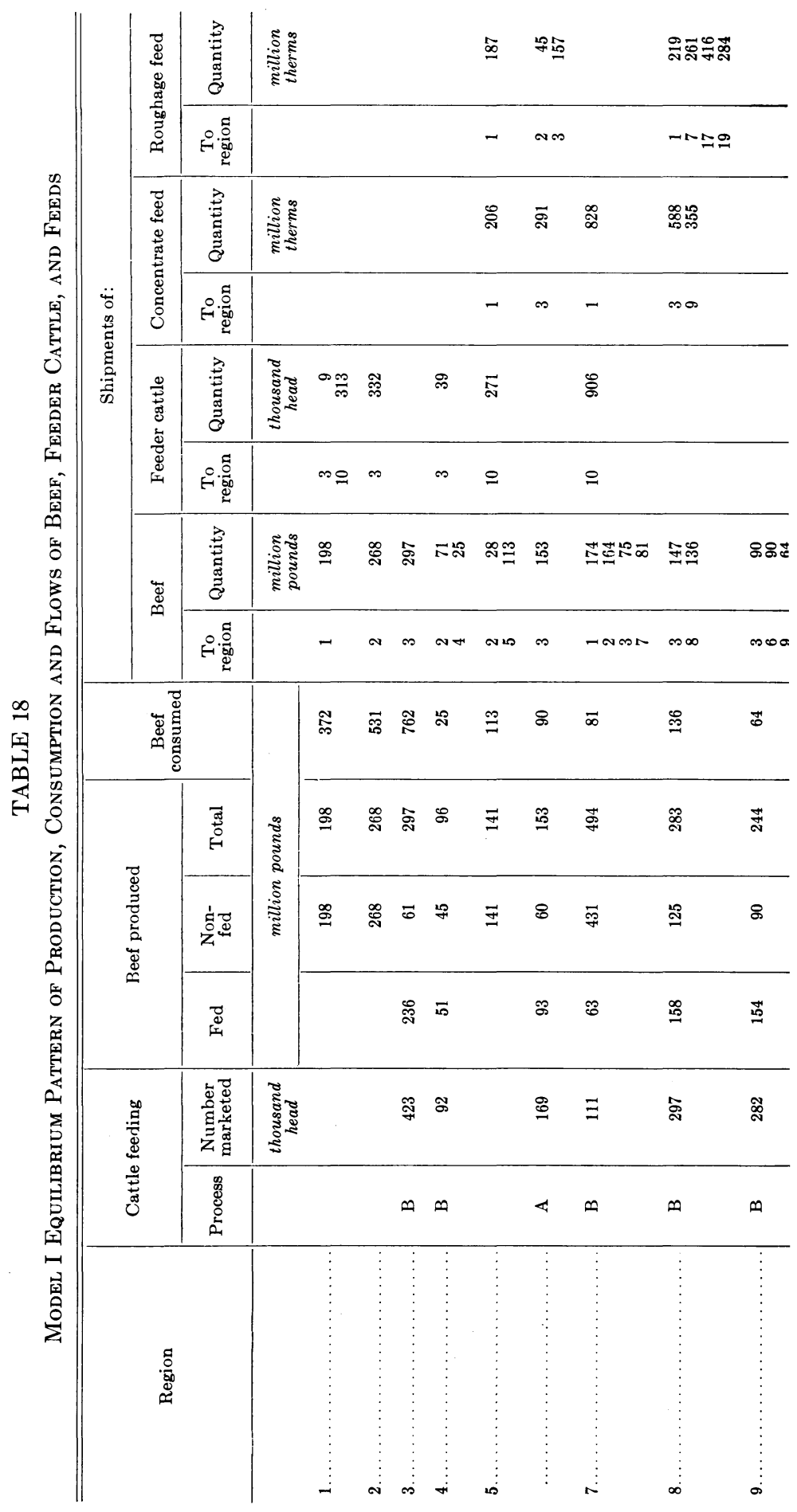




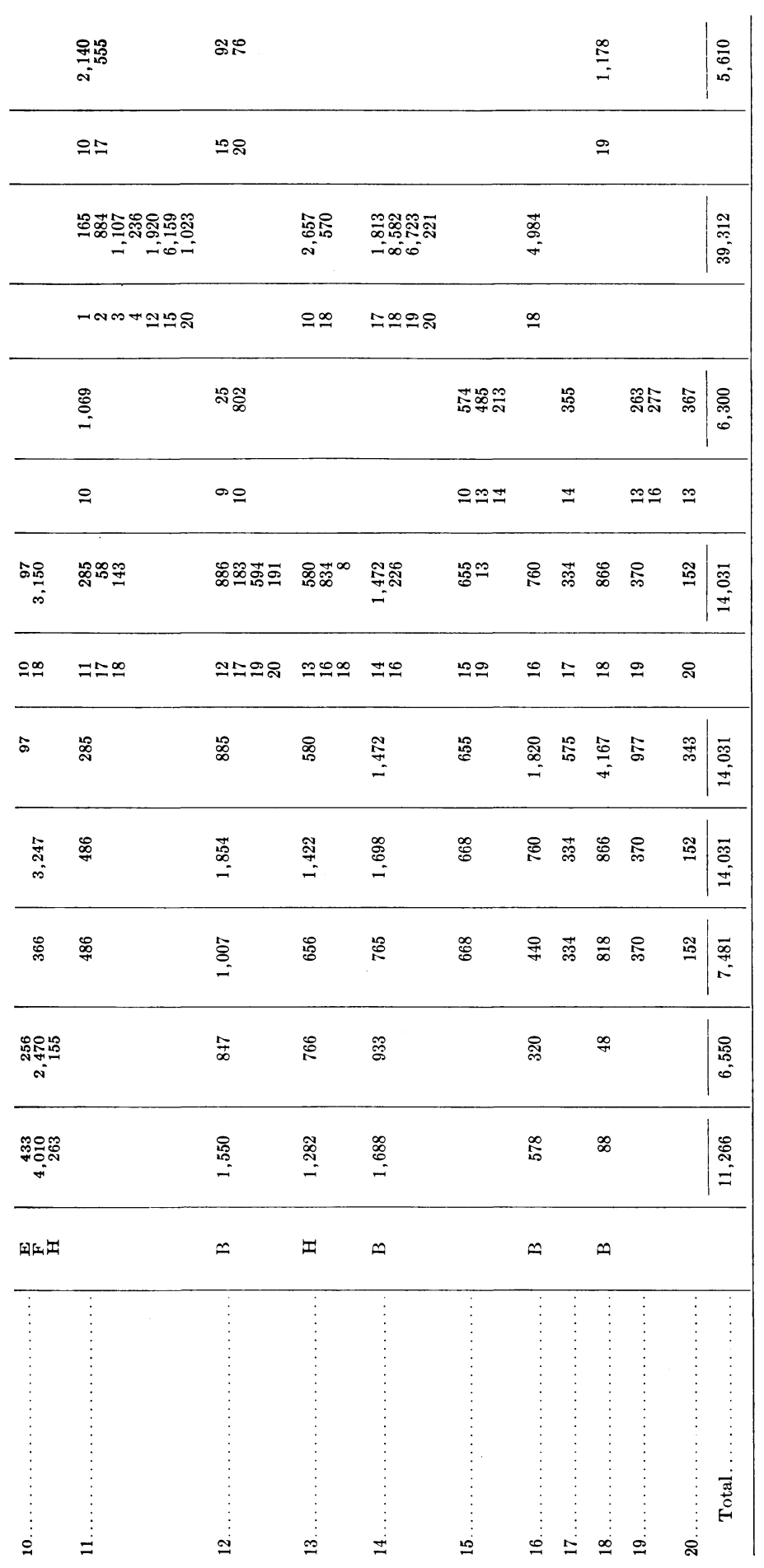


In region 10 , three feeding activities are included in the solution, of which activities $\mathrm{E}$ and $\mathrm{H}$ have equal concentrate-roughage ratios, and $\mathrm{F}$ has a higher concentrate-roughage ratio. A solution of this nature may occur in programming problems when the price ratio of the feeds (imputed prices in this model) approximates the slope of the line connecting activities $\mathrm{F}$ and $\mathrm{B}$ (see figure 4). With given limiting resources, the program will select those activities that fulfill production requirements such as to maximize the objective function. In this case, it was accomplished by utilizing three production activities in region 10 . If a continuous isoquant could be specified of the usual shape (convex to the origin) the price line would be tangent at one point, resulting in a unique concentrate-roughage ratio. Further, there would be a unique level of feeding, rather than activities $\mathrm{E}$ and $\mathrm{H}$ if the program could be specified for continuous rather than discrete weight-gain production activities.

The quantity of beef consumed by region is composed of the total of fed and nonfed beef, and in equilibrium, the regional quantity consumed must be consistent with the regional price. Since a demand function is used, this means that a set of prices is assumed and a set of consumption levels calculated using the demand function for each region. The problem is run and the results checked for consistency of prices and quantities. In model I, five revisions of prices and quantities were required to bring about the required equilibrium conditions.

Shipments of meat are specified both for shipments within the region and for interregional shipments. Thus, total shipments for the 20 regions are equal to the total beef consumed and also to the sum of fed beef produced and nonfed beef available. Since the transportation costs for shipments within the re- gion are less than for interregional shipments, consumption needs are met, if possible, from within the region. ${ }^{10}$ This has resulted in the consumption for a region being met entirely with nonfed beef, such as for region 5, for example. This prompted an alternative specification for the consumption of beef between fed and nonfed beef, as given in model IV.

Shipments of feeder cattle, feed concentrates and roughage are indicated only for interregional shipments. The difference between regional availability and shipments are used within the region. The difference between intermediate product shipments and meat shipments is due to the model specification of transportation costs. For intermediate products; transfer costs between regions represent net costs or the difference between interregional rail costs and within-region truck costs. The use of net transfer costs thus evaluates the relative ability of a surplus or deficit region to bid for feed or feeder cattle supplies at the feedlot location (see discussion on page 340). For meat shipments, within-region transfer costs are required for shipments of nonfed beef that are available in each region to meet consumption requirements.

The pattern of shipments for meat and intermediate products is shown in figure 5 for results obtained under model I. Meat deficits on the West Coast are met by shipments from within the western region, and deficits on the East Coast are met by shipments from the Midwest and Southern Plains.

Feeder cattle shipments, shown in section $\mathrm{B}$ of figure 5, reflect feeding locations under model $I$ and regional availability of feeder cattle. As will be discussed in detail, the feeding locations differ considerably from those actually existing in 1958, as shown in figure 6 . The regional availability of feeder cattle for model $\mathrm{I}$ is given in table 19 , which

\footnotetext{
${ }^{10}$ An exception is region 6 for which no intraregional shipments are shown. This resulted from an incorrect specification of the within-region transportation rate which was lowered in subsequent analyses. The resulting difference in cost is negligible with the present shipment pattern.
} 


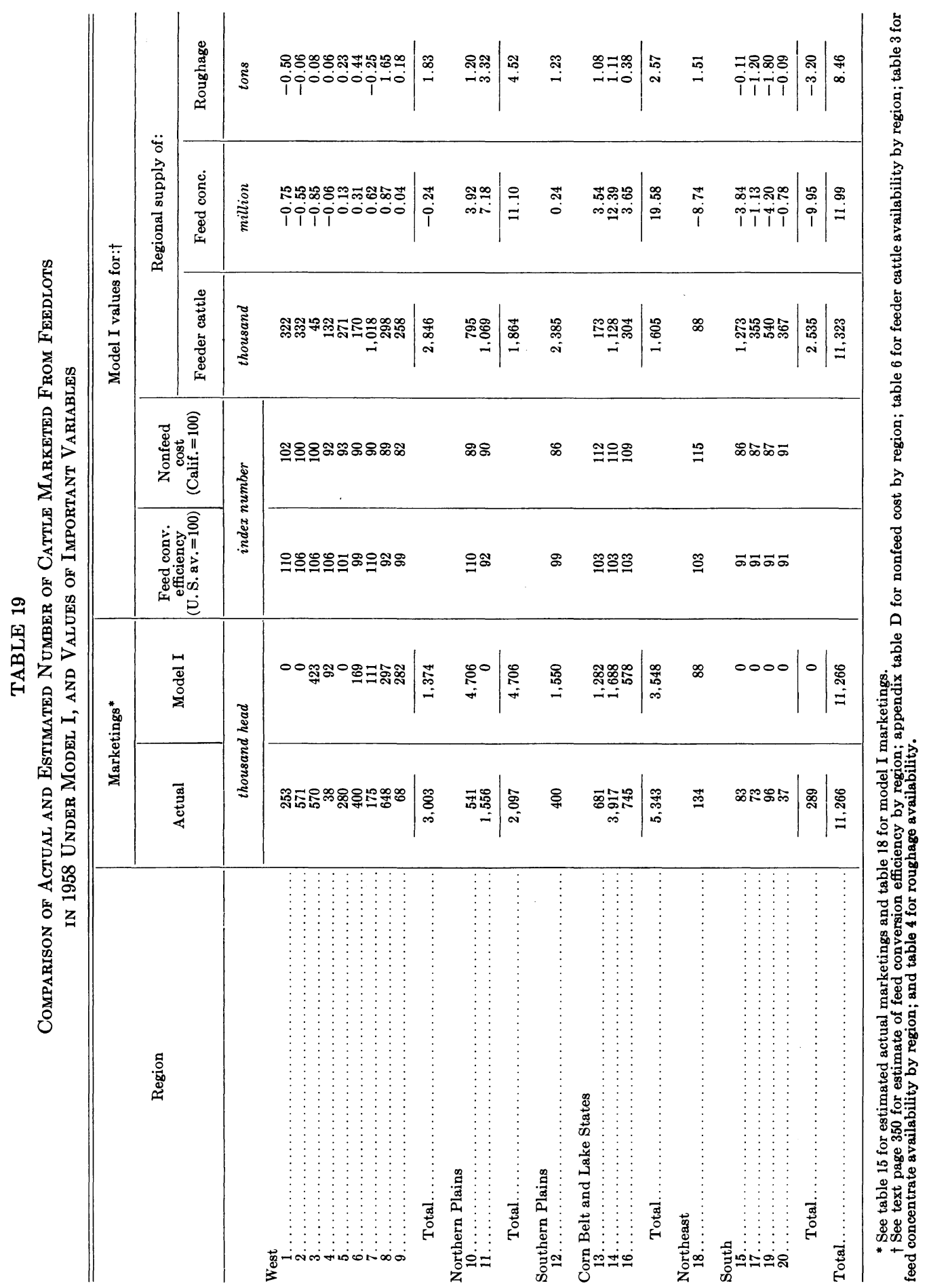



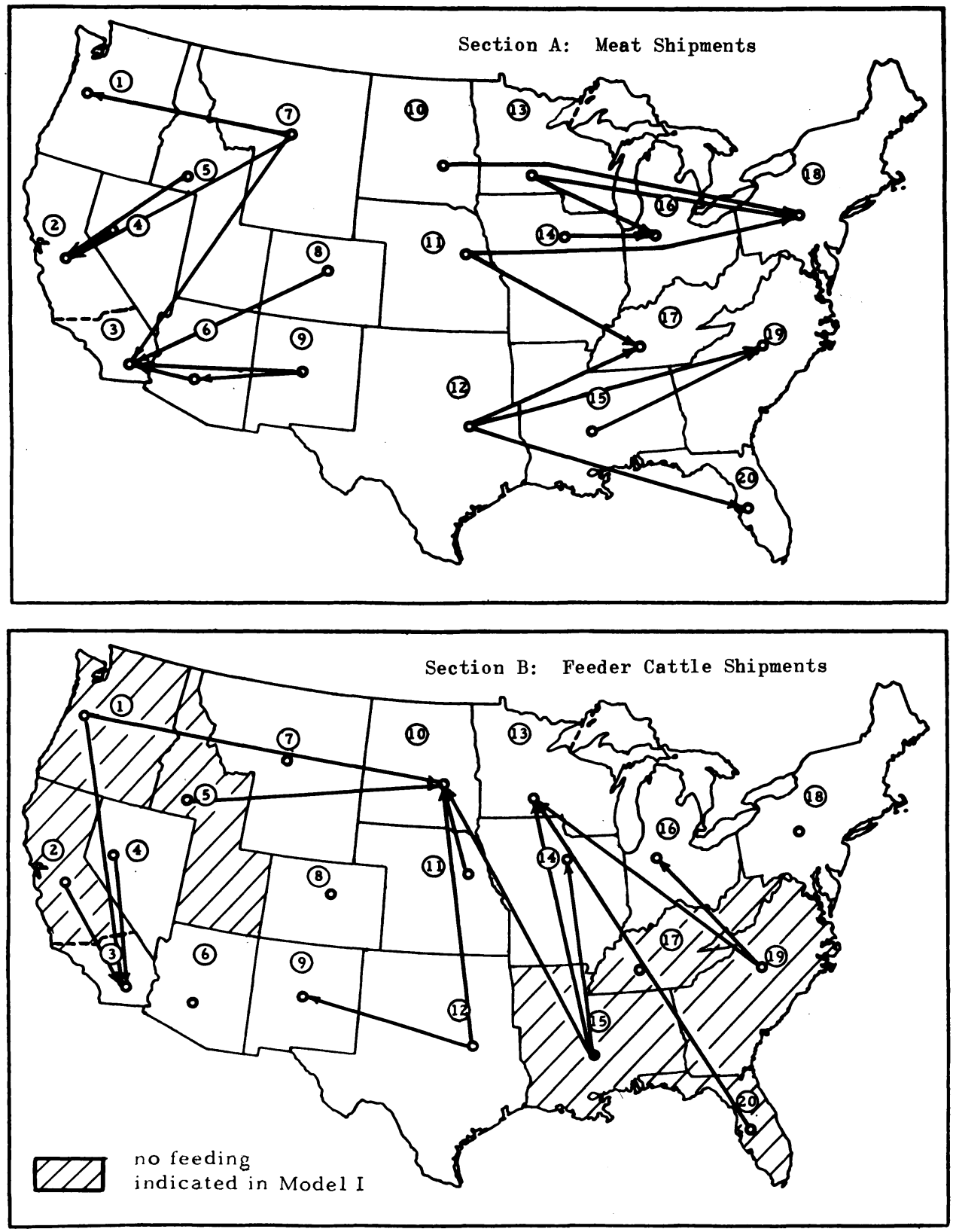

Fig. 5A and B. Model I shipments of meat and feeder cattle.

also provides a summary of the values used in model I for feed conversion efficiency, nonfeed costs, and regional supplies of intermediate products.

Shipments of feed concentrates and hay are shown in sections $\mathrm{C}$ and $\mathrm{D}$, re- spectively, of figure 5. The shaded areas indicate regions in which no feeding was indicated under model I. Thus, shipments to these regions were required only to meet the regional deficits of concentrates and/or hay as indicated in 

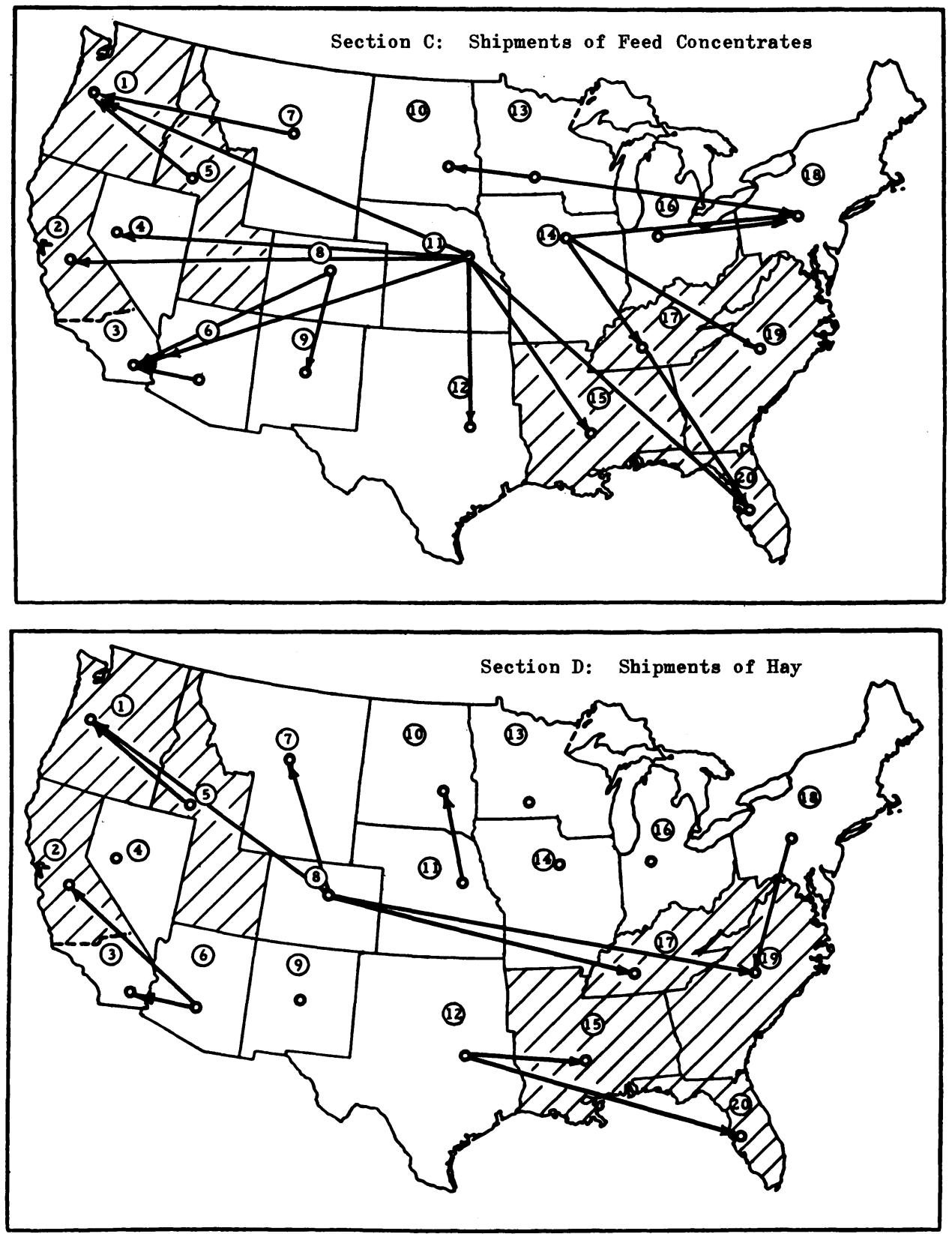

Fig. 5C and D. Model I shipments of feed concentrates and hay.

table 19. This shipment pattern has associated with it a pattern of imputed prices obtained from the dual solution. These prices provide a basis of comparison with actual regional prices. The fact that regional deficits were specified for certain regions illustrates the partial equilibrium nature of this model. This would not have been required if all livestock production were considered to be variable. The use of grain other than for feed is an added complication. 


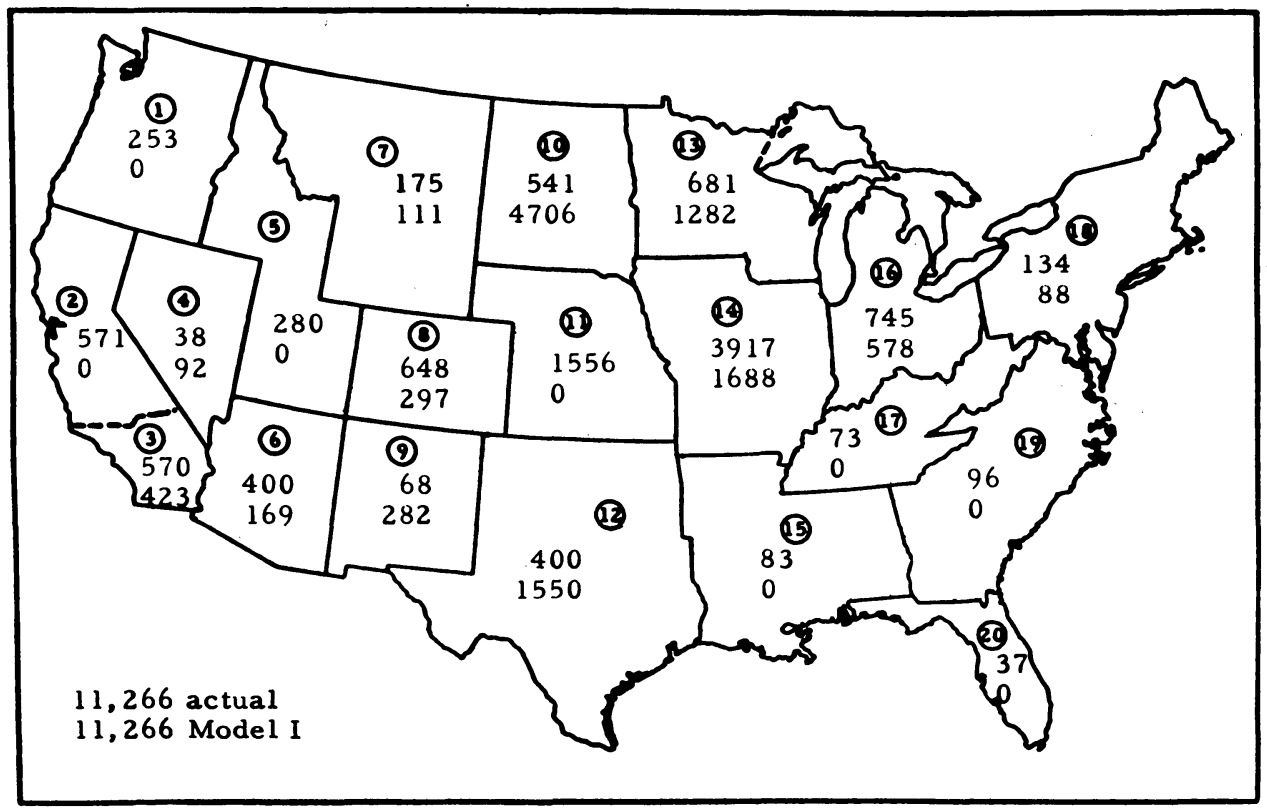

Fig. 6. Number of cattle marketed (in thousands) in 1958, by region, actual and estimated from model I.

\section{Comparison of Location- Actual and Model I}

A comparison of the location of regional marketings from feedlots under model I with actual 1958 marketings indicates important differences as indicated in table 19. Marketings are higher under model I especially for the Northern Plains and Southern Plains areas, whereas marketings from the West and Corn Belt and Lake States are much lower than actual 1958 marketings. Marketings are indicated for 12 of the regions used in model $I$ as compared with actual marketings in 20 regions.

The model solution indicates the optimum location if conditions specified as to intermediate product supply, production functions, nonfeed costs, demand functions, and transportation functions accurately represent the economic situation at a particular time and were to remain in effect unchanged for such period that complete adjustment to these conditions could be made. Suppose that such is the case. What is the degree of inefficiency of the actual 1958 location pattern? Henderson (1958) presents a measure of the efficiency of the actual regional distribution of output as compared with an efficiency norm, which is in this case the location pattern indicated in model I. This measure may be expressed as follows:

\section{Total efficient output- misallocated output \\ Total efficient output}

where misallocated output is defined as the sum of the absolute deviations of the actual from the norm divided by two. The division by two is required to eliminate double counting; that is, if one region produces too much, some other region must produce too little.

The index of efficiency of actual feedlot locations for the 20-region breakdown of the United States equals 44, which reflects the wide divergence between actual and model I regional marketings. The index for the 6-region breakdown shown in table 19 is 67 , re- 
flecting the offsetting differences within the aggregated subregions (such as regions 10 and 11, for example).

We next inquire as to the stability of the optimum location pattern found in model I. This will be done in two phases, the first of which assumes that the specifications of the model as to feeding efficiency, nonfeed costs, and the nature of demand for beef are correct, and the second phase which traces the effect of changes in the assumptions noted above. The second phase is developed in the discussion of models, II, III, and IV. The first phase, which utilizes the dual solution of model I, is discussed next.

\section{Cost of Shifting Location of Feeding}

The direct solution of the linear programming problem gives that location of feeding which will maximize the value of the objective function. We now ask how much would costs be increased by introducing feeding activities (or locations) not in the optimum program. This information is provided in the dual solution of any programming problem giving the partial derivative of the objective function with respect to each of the activities not in the solution. The value of the derivative is a guide to the cost associated with introducing a feeding activity in the 8 of the 20 regions in which feeding was actually done in 1958 and for which there was no feeding indicated in the optimum program. Information provided in the dual is also useful in analyzing the costs associated with shifting locations of feeding between a pair of feeding areas in the optimum program, although the computations are more involved and less precise.

Nonfeeding regions.-Some cattle feeding was done in all 20 regions in 1958 , but in only 12 regions in model I. The cost associated with introducing one unit ( 1,000 pounds of carcass beef) of the feeding activity that would increase costs the least are indicated in table 20 for model I (and also for models II and III) for each of the eight nonproducing regions. These values are taken from the dual solution of model I and represents the least-cost feeding activity of the possible nine alternatives available for each region. The cost associated with introducing more than one unit of a feeding activity in any one of these regions would cost at least that amount shown and probably more as the entire shipment patterns for intermediate products would be changed. ${ }^{20}$

With the exception of region 5 and perhaps 11, the introduction of feeding activities in these regions and the associated flows of intermediate products appears to add considerably to the cost of producing beef to meet consumption requirements. Consider region 2 , for example, for which the cost of introducing feeding activity $B$ equals $\$ 6.63$ per 1,000 pounds of carcass beef. This cost for the first unit equals one and one-half percent of the equilibrium price of beef in the region at the feedlot location. ${ }^{21}$

The regional disadvantage for region 2 may well be less than indicated if actual production conditions differ in important respects from those specified in the model. Two of these factors are mentioned brifly here and discussed in more detail subsequently. Large feedlots are more prevalent in California than in many areas of the country. Nonfeed costs, due to economies of scale, may well be lower than in other areas, thus resulting in lower production costs. Another consideration is that cattle of lighter weight than 650 pounds may be shipped into areas such as California to be fed on seasonal range, irrigated pasture, grazed on beet tops, and other

\footnotetext{
${ }^{20}$ To calculate the exact amount of the additional cost to the system for a specified level of feeding in a given region, the problem could be rerun with a restraint specifying a given level of feeding in the region.

21 The price at the feedlot equals the equilibrium market price of $\$ 456.58$ per 1,000 pounds of carcass less the within transportation cost of $\$ 3.45$ per 1,000 pounds to ship from the feedlot (and slaughter plant which is identically located) to the market.
} 
TABLE 20

Cost of Introducing Feeding Activities in Regions Not Feeding Cattle in Optimum Solution*

\begin{tabular}{|c|c|c|c|c|c|c|}
\hline \multirow{2}{*}{ Region } & \multicolumn{2}{|c|}{ Model I } & \multicolumn{2}{|c|}{ Model II } & \multicolumn{2}{|c|}{ Model III } \\
\hline & $\begin{array}{l}\text { Feeding } \\
\text { activity }\end{array}$ & $\begin{array}{l}\text { Cost per } 1,000 \\
\text { pounds }\end{array}$ & $\begin{array}{l}\text { Feeding } \\
\text { activity }\end{array}$ & $\begin{array}{l}\text { Cost per } 1,000 \\
\text { pounds }\end{array}$ & $\begin{array}{l}\text { Feeding } \\
\text { activity }\end{array}$ & $\begin{array}{l}\text { Cost per } 1,000 \\
\text { pounds }\end{array}$ \\
\hline & & dollars & & dollars & & dollars \\
\hline 1. & B & 7.14 & B & 5.42 & C & 12.44 \\
\hline 2. & B & 6.63 & B & 6.30 & B & 8.10 \\
\hline 5. & B & .42 & .. & $\ldots \ldots$ & B & 2.04 \\
\hline 7. & .. & $\ldots \ldots$ & $\mathbf{E}$ & .91 & B & 7.76 \\
\hline 11. & B & 3.12 & $\mathbf{H}$ & 3.32 & & $\ldots$ \\
\hline 15. & B & 20.52 & B & 21.64 & B & 6.99 \\
\hline 17. & C & 17.78 & C & 20.94 & C & 7.54 \\
\hline $19 .$. & $\mathrm{C}$ & 23.46 & $\mathrm{C}$ & 27.64 & $\mathrm{C}$ & 10.15 \\
\hline 20 . . & C & 27.16 & C & 27.75 & C & 11.29 \\
\hline
\end{tabular}

* Cost in dollars per 1,000 pounds of beef produced for introducing feeding activity with lowest additional cost. These values are the partial derivatives of the objective function (returns) with respect to each activity in the program given the level of all other activities.

sources of weight gain. Under this specification, the feeder cattle would be located in California and the cost of shipment of feeder animals would be much lower than indicated under the present model. As noted previously, the roughage availability data are subject to severe limitations and may well affect the results, due to the relatively high cost of interregional shipments of hay.

Feeding regions.-For regions in which feeding was shown in the optimum program of model I, the largest absolute differences between actual and estimated numbers occurred in regions 10 (North and South Dakota) and 14 (Illinois, Iowa, and Missouri). The increased feeding in region 10 and the decreased feeding in region 14 accounts for approximately one-half of the total "misallocated" output in the efficiency index. The cost associated with a shift of feeding from one region to the other is thus of particular interest.

In contrast to the use of the dual solution for introducing feeding activities into nonfeeding areas, calculations here require changes in the level of feeding activities included in the optimum solution for regions 10 and 14. This involves changes not only in the feeding activity, but the related changes in the meat ship- ment pattern, and the shipments of feeder cattle, feed concentrates, and hay. An added complication is the restriction of the program that regional prices for beef are interconnected by transportation costs, and are a function of the quantity of beef shipped. An approximation to the added costs of shifting one unit of production from 10 to 14 is given in the following calculations, but a more precise indication of the shift in location due to change in costs is discussed under model II in which the level of nonfeed costs is equalized in all regions. This change results in wiping out a cost advantage of $\$ 5.30$ per 1,000 pounds of beef which region 10 held over region 14 in model $\mathrm{I}$, with a resulting shift of approximately 1,500,000 head from region 10 to region 14 . It becomes clear that the locations specified may rest on fairly small differences in costs.

Using values of the dual solution we may proceed as follows: Nearly all of the production of fed cattle in region 10 is shipped as meat to region 18. If feeding in region 14 were to be increased above that shown in the model, some additional cost might be involved in meat shipments for the entire model. As an indication of this cost, we take the ad- 
TABLE 21

Regional Marketings Under Model II and Actual 1958 Marketings, and Change from Model I to Model II With Equal Regional Nonfeed Costs

\begin{tabular}{|c|c|c|c|c|c|c|c|}
\hline \multirow{3}{*}{ Region } & \multirow{2}{*}{\multicolumn{2}{|c|}{$\begin{array}{l}\text { Marketings of fed } \\
\text { cattle under:* }\end{array}$}} & \multicolumn{5}{|c|}{ Change from Model I in: } \\
\hline & & & \multicolumn{2}{|c|}{ Feeding activity in: } & \multirow{2}{*}{$\begin{array}{c}\text { Nonfeed cost } \\
\text { per } 1,000 \\
\text { pounds of } \\
\text { carcass beef } \dagger\end{array}$} & \multicolumn{2}{|c|}{ Number of head marketed } \\
\hline & Actual & Model II & Model I & Model II & & Absolute & Percentage \\
\hline & $\begin{array}{c}\text { thousand } \\
\text { head }\end{array}$ & $\begin{array}{l}\text { thousand } \\
\text { head }\end{array}$ & & & dollars & thousand & per cent \\
\hline \multicolumn{8}{|l|}{ West } \\
\hline 1.. & 253 & 0 & .. & .. & $-0.05 \ddagger$ & & \\
\hline $2 .$. & 571 & 0 & .. & .. & $0.00 \ddagger$ & & \\
\hline $3 \ldots$ & 570 & 527 & $\mathrm{~B}$ & B & 0.00 & +104 & +25 \\
\hline $4 \ldots$ & 38 & 92 & B & B & +1.80 & $\mathbf{0}$ & \\
\hline 5.. & 280 & 1 & .. & B & +1.25 & +1 & \\
\hline 6. & 400 & 169 & A & A, B & +1.38 & 0 & \\
\hline $7 \ldots$ & 175 & 0 & B & .. & +2.61 & -111 & -100 \\
\hline $8 \ldots \ldots \ldots \ldots$ & 648 & 297 & B & $\mathbf{H}$ & +1.96 & 0 & 0 \\
\hline $9 \ldots$ & 68 & 257 & B & $\mathrm{B}, \mathbf{E}$ & +3.80 & $-\quad 25$ & -9 \\
\hline Total... & 3,003 & 1,343 & & & & $-\quad 31$ & -23 \\
\hline \multicolumn{8}{|l|}{ Northern Plains } \\
\hline $10 \ldots \ldots \ldots \ldots$ & 541 & 3,278 & $\mathrm{E}, \mathrm{F}, \mathrm{H}$ & H, I & +3.07 & $-1,428$ & -30 \\
\hline $11 \ldots \ldots \ldots \ldots$ & 1,556 & 0 & . & .. & $+1.28 \ddagger$ & & \\
\hline Total.. & 2,097 & 3,278 & & & & $-1,428$ & -30 \\
\hline \multicolumn{8}{|l|}{ Southern Plains } \\
\hline $12 \ldots \ldots \ldots \ldots$ & 400 & 1,329 & B & B & +2.75 & -221 & -14 \\
\hline \multicolumn{8}{|l|}{ Corn Belt and Lake States } \\
\hline $13 \ldots \ldots \ldots \ldots \ldots \ldots \ldots$ & 681 & 1,282 & $\mathbf{H}$ & $\mathbf{H}$ & -2.39 & 0 & 0 \\
\hline $14 \ldots \ldots \ldots \ldots \ldots \ldots \ldots$ & 3,917 & 3,107 & B & $\mathrm{B}, \mathrm{E}$ & -2.55 & $+1,419$ & +84 \\
\hline $16 \ldots \ldots \ldots$ & 745 & 578 & B & B & -2.43 & 0 & 0 \\
\hline Total. & 5,343 & 4,967 & & & & $+1,419$ & +40 \\
\hline \multicolumn{8}{|l|}{ Northeast } \\
\hline 18. & 134 & 349 & B & B & -3.64 & +261 & +297 \\
\hline \multicolumn{8}{|l|}{ South } \\
\hline $15 \ldots$ & 83 & 0 & .. & .. & $+2.16 \ddagger$ & & \\
\hline $17 .$. & 73 & 0 & .. & .. & $+1.84 \ddagger$ & & \\
\hline 19. & 96 & $\mathbf{0}$ & .. & .. & $+2.05 \ddagger$ & & \\
\hline 20. & 37 & 0 & .. & .. & $+1.00 \ddagger$ & & \\
\hline Total. & 289 & 0 & & & & & \\
\hline Total. & 11,266 & 11,266 & & & & 0 & \\
\hline
\end{tabular}

* See table 15 for estimated actual marketings and table 22 for model II results.

t For regions with multiple feeding activities, nonfeed costs are weighted by numbers fed under each activity. The absolute level of nonfeed costs, shown in appendix table D, are set equal to region 3 in model II which equal \$23.11 for activity $B$, for example.

$\ddagger$ For regions with no feeding under models $I$ and II, the change in nonfeed costs is that for feeding activity B.

ditional cost of shipments of meat from region 14 to 18 of $\$ 0.48$ per 1,000 pounds. To produce 1,000 pounds of carcass beef in region 14 by feeding activity $\mathrm{B}$ requires 1.8873 head of feeders, 0.9649 thousand therms of net energy of roughage, and 2.6969 thousand therms of net energy of concentrate feed. The cost of additional feeder shipments to region 14 from the following regions involves the cost indicated per head:

$\begin{array}{cr}\text { REGION } & \text { COST } \\ 20 & \$ 0.15 \\ 19 & .60 \\ 12 & 1.10 \\ 11 & 2.46\end{array}$

Assuming that feeder shipments were made from region 12 , the added cost per 


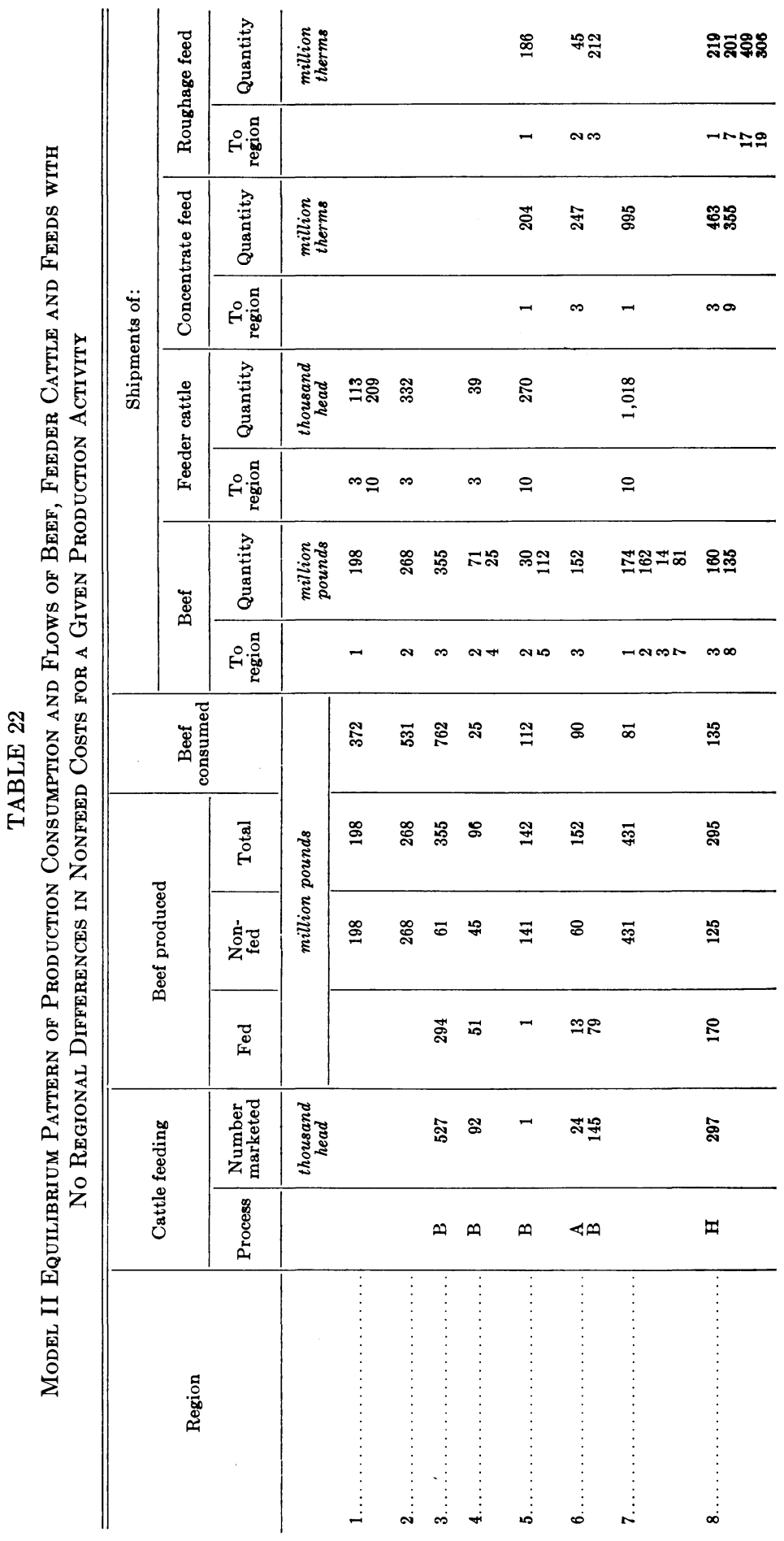




\begin{tabular}{|c|c|c|c|c|c|c|c|c|c|c|}
\hline & & 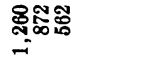 & $\stackrel{\infty}{\infty} \underset{=}{=}$ & & & & & $\stackrel{\infty}{\circ}$ & & 总 \\
\hline & & 요ㅍㅡㅡ & 모요 & & & & & $\Phi$ & & \\
\hline & & 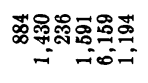 & & స్ & 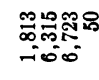 & & $\begin{array}{l}\overrightarrow{0} \\
\underset{\sigma}{+} \\
\stackrel{+}{+}\end{array}$ & & & $\mid$ \\
\hline & & 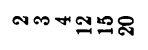 & & $\stackrel{\infty}{\sim}$ & 표모주 & & $\stackrel{\infty}{\simeq}$ & & & \\
\hline & & $\underset{-\infty}{\$ 0}$ & 욤 & & & $\stackrel{\overbrace =}{=}$ & : & คี & సิ స్ & 范 \\
\hline & & 요 & $\cong$ & & & \pm & \pm & & $\stackrel{\infty}{ \pm}$ & \\
\hline ๓8\% & 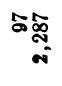 & 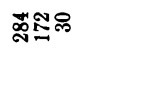 & 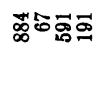 & 맘요 & 栗商 & 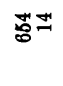 & 总响 & $\Xi_{-\infty}$ & 옹 ชู & $\mid \begin{array}{l}0 \\
0 \\
0 \\
\vdots\end{array}$ \\
\hline$n 00$ & 요요 & 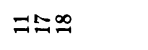 & 츠몽 & $\stackrel{2}{2}$ & $=0$ & $\because 9$ & $\cong=$ & $\stackrel{\infty}{=}$ & 9 ㅇ & \\
\hline$\check{\Xi}$ & $a$ & 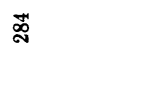 & 苂 & 禺 & $\underset{8}{\stackrel{8}{-1}}$ & 范 & $\stackrel{\substack{0 \\
0}}{=}$ & $\stackrel{\circ}{\circ}$ & ๕ \% & $\mid \begin{array}{l}0 \\
0 \\
0 \\
=\end{array}$ \\
\hline 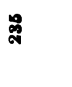 & 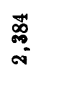 & $\stackrel{\mathscr{\infty}}{+}$ & $\stackrel{\substack{\overparen{T} \\
=}}{=}$ & $\stackrel{\mathscr{7}}{=}$ & $\stackrel{0}{0}$ & 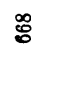 & $\stackrel{8}{\circ}$ & $\overrightarrow{0}_{-}^{\circ}$ & 옳 옥 & $\mid \begin{array}{l}0 \\
0 \\
\pm \\
\pm\end{array}$ \\
\hline 8 & \& & $\stackrel{\infty}{\leftrightarrow}$ & 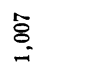 & : & $\stackrel{80}{: 0}$ & 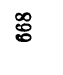 & 累范 & $\stackrel{\infty}{\infty} \stackrel{\circ}{\infty}$ & 옳 혹 & 悪 \\
\hline \$ప్ & 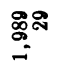 & & ๙̊ำ & $\widehat{\circ}$ & 被足 & & శ్లి & $\cong$ & & 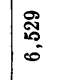 \\
\hline 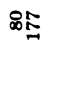 & $\begin{array}{c}\overrightarrow{g_{0}^{2}} \\
\text { on }\end{array}$ & & $\stackrel{\text { హ్ }}{-}$ & $\stackrel{\mathscr{\circ}}{\leftrightarrows}$ & ్ㅐㅇㅛ & & $\stackrel{\infty}{\stackrel{\infty}{i 0}}$ & \$요 & & 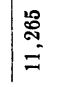 \\
\hline 国風 & 圷 & & $\infty$ & 斗 & 뫼요 & & $\infty$ & $\infty$ & & \\
\hline$\vdots$ & $\begin{array}{l}\vdots \\
\vdots \\
\vdots\end{array}$ & $\dot{\vdots}$ & ต & $\stackrel{\dot{m}}{\dot{a}}$ & \pm & $\vdots$ & $\begin{array}{rr}\vdots & \vdots \\
\subseteq & \vdots\end{array}$ & $\vdots$ & \begin{tabular}{cc}
$\vdots$ & $\vdots$ \\
$\vdots$ & $\vdots$ \\
\hdashline & व
\end{tabular} & $\begin{array}{c}\vdots \\
\vdots \\
\vdots \\
\vdots \\
\vdots \\
\vdots \\
\text { ग़ं } \\
\stackrel{5}{0}\end{array}$ \\
\hline
\end{tabular}


1,000 pounds of beef produced would be $\$ 2.00$ (i.e., $\$ 1.10$ times 1.8873 , the number of head of feeders required per thousand pounds of carcass beef produced). The added roughage could be obtained from region 11 at an added cost per 1,000 pounds of beef produced of $\$ 1.54$ (i.e., $\$ 1.60$ times 0.9649 ). Since region 14 ships out concentrate feed, changes in these costs will be ignored. The added cost associated with these shifts amounts to $\$ 4.02$ per 1,000 pounds of beef. The equilibrium price of beef in region 18 equals $\$ 46.33$ per hundred weight of carcass beef. Thus, the increased cost equals less than one per cent of the market price, and the entire shift in production may rest on as little as four-tenths of a cent a pound for carcass beef. This estimate of costs, although a rough indication, appears to be in line with that provided in model II.

\section{MODEL II}

Model II is designed to determine the effect of differences of nonfeed costs among regions on the location of cattle feeding. This is accomplished by analyzing feeding locations under model I for which nonfeed costs differed by region according to feedlot construction costs and farm wage rates, and locations under model II for which nonfeed costs were set equal to that for California for all regions. These costs differ, however, for the various feeding activities within a given region due to varying length of feeding period. The change in the nonfeed costs between models I and II are given in table 21 and relate to the feeding activity selected in the optimum programs for feeding areas, and for feeding activity $B$ for nonfeeding areas.

The shifts in feeding locations, shown in table 21 , provide a convenient summary, although the detailed optimum solution for model II gives a more comprehensive picture of the equilibrium pattern of production, consumption, and shipments (see table 22).
An increase in nonfeed costs from model I to model II was introduced in 13 regions, a decrease in five regions, and no change in the remaining two regions. The results were in general consistent with expectations; namely, that an increase (decrease) in nonfeed costs was associated with a decrease (increase) in the number marketed from a particular region.

Increased nonfeed costs introduced into 13 regions resulted in decreased feeding in four regions $(7,9,10,12)$ as might be expected, no change took place in three regions $(4,6,8)$, an increase in feeding took place in region 5; and no feeding was introduced in either model I or II for five regions $(11,15,17,19$, 20).

No change in nonfeed costs were made in regions 2 and 3 . In region 3 , however, feeding increased, whereas in region 2, no feeding was introduced under either model.

Decreased nonfeed costs were introduced in five regions. The number of cattle fed increased in two regions (14, 18) as might be expected, no change took place in two regions $(13,16)$, and no feeding was introduced into region $I$.

Regional interrelationships as to shipments of beef and intermediate products do not allow a simple statement of the possible effect of a given level of change in nonfeed costs. This is shown more clearly by a more detailed analysis of change in feeding location by region.

West.-The eight states included in these regions comprise the Western region. In both models I and II, the production of meat (fed and nonfed) within the Western region just equals consumption. This region is interconnected with other regions by shipments of intermediate products-net outshipments of feeder cattle and roughage, and net inshipments of concentrate feed.

In setting nonfeed costs equal to that in California (regions 2 and 3 ), all nine regions except region 1 faced higher costs in model II than in model I. This resulted in the following changes: 
1. Numbers of head marketed in the Western region decreased 31,000 head, but changes in the feeding activities were such that production decreased by only 2 million pounds. This shift to longer feeding periods results in lower feeder cattle requirements per 1,000 pounds of carcass beef produced.

2. Feeding was increased in region 3 with a major offsetting decrease in region 7 and also in region 9 . The increased production in region 3 of 58 million pounds was balanced by decreased shipments from region 7 (61 million), region 9 (9 million), region 6 ( 1 million), and by increased shipments from region 8 (13 million).

3 . The length of feeding period was increased in regions 8 and 9, indicated by a shift from feeding activity $\mathrm{B}$ to $\mathrm{H}$ in region 8 , and a partial shift to feeding activity $\mathbf{E}$ in region 9 .

4. Feeding was introduced in region 5 in model II. This result might have been expected from inspection of the dual solution of model I (see table 20), since this feeding activity had the lowest cost for any of the eight regions not feeding cattle in the optimum solution.

5. The cost of introducing feeding activities in regions not feeding cattle in model II, as indicated in table 20 , indicates a substantial reduction from model I costs for region 1 and a slight reduction for region 2. Reintroducing feeding in region 7, however, would be accomplished at a considerably lower cost than for regions 1 or 2 .

Northern Plains.-This region is composed of the four states of North and South Dakota (region 10), Kansas, and Nebraska (region 11). In both models I and II, results indicate inshipments of feeder cattle and outshipments of meat and also feed concentrates and roughage. The principal change between the two programs is the decrease in num- bers fed in region 10 due to the increased nonfeed costs. As noted previously, this change resulted in a shift in feeding location from region 10 to 14 . The relative disadvantage of region 11 was increased slightly due to the increased nonfeed costs, as shown in table 21 , but by an amount far less than the increased nonfeed costs. This is due to the interrelated changes in shipment patterns in the entire program.

Southern Plains.-The states of Oklahoma and Texas comprise region 12 . In both models, results indicate outshipments of beef, feeder cattle, and roughage, and inshipments of concentrate feeds. The level of feeding in both programs is higher than the "actual" 1958 level. The principal change in model II is the decrease in the level of feeding due to relatively higher nonfeed costs.

Corn Belt and Lake States.-The Corn Belt comprises the states of Illinois, Iowa, Missouri (region 14), Indiana, and Ohio (region 16 which also includes Michigan). The Lake States include Minnesota, Wisconsin, and Michigan (region 13 which excludes Michigan). These eight states comprised the major feeding area under "actual" 1958 conditions, and under model II. In both models I and II, feeders are inshipped to all three regions $(13,14,16)$; meat is outshipped from regions 13 and 14 including shipments to region 16 which does not produce enough to meet consumption requirements; concentrates are shipped from all three regions. For roughage, no shipments in or out of the regions are indicated under model I, whereas under model II, roughage is shipped from region 11 to region 14 .

The major change from model $\mathrm{I}$ is the shift in feeding to region 14 . Concentrate outshipments from region 14 were reduced. Roughage shipments were introduced from region 11 to 14, with a corresponding decrease in shipments from region 11 to 10 where feeding was reduced. Similarly, feeder cattle inshipments were increased from region 15 with a corresponding decrease in feeder 
shipments from region 15 to 10 . This shift in location between region 14 and 10 is associated with a change in relative nonfeed costs of about $\$ 5.40$ per 1,000 pounds of carcass beef.

Northeast.-The eleven states of this area comprise the major deficit region for beef shipments, with local production accounting for about 2 per cent of consumption requirements under model I and about 8 per cent under model II. It also is a deficit region in feed concentrate supplies. The major change between model I and II was an increase in feeding in the region, accomplished by an inshipment of feeder cattle from region 19 accompanying a decrease in outshipment of hay to this region, and increased inshipments of concentrate feed. Nonfeed costs were decreased by $\$ 3.64$ per 1,000 pounds of carcass beef in model II.

South, excluding the Southern Plains.-This area includes region 15 (Alabama, Arkansas, Louisiana, and Mississippi), region 17 (Kentucky, Tennessee, and West Virginia), region 19 (Georgia, South Carolina, North Carolina, and Virginia) and region 20 (Florida). Although the feeder cattle availability in this region is second only to the Southern Plains, the amount of feeding actually done in 1958 was relatively small. In both models I and II, no feeding was indicated, with the costs associated with introducing feeding in these regions higher under model II than under model I (see table 20). These regions serve as an important source of feeder cattle for the major feed-producing areas. Feed is shipped into these regions to supply needs for other livestock and the large poultry industry. Increases in cattle feeding would appear to depend primarily on the opportunity costs associated with alternative livestock production.

In summary, nonfeed costs per 1,000 pounds of carcass beef are equal in all regions for a given feeding activity for model II. The resulting pattern of location of feeding corresponds more nearly to "actual" 1958 locations than that for model I. For the 20 region breakdown, model II indicates an efficiency index of 58 compared to 45 for model I.

The major shifts in location of production from model I include the following: (1) Increased feeding in the Corn Belt in region 14 and a corresponding decrease in the Northern Plains in region 10; (2) decreased feeding in the Southern Plains; (3) increased feeding in the Northeast; and (4) shifts in feeding within the Western region but maintaining regional selfsufficiency in meat. The level of nonfeed costs appear to have an important influence on location in this model. The most important shift, that between region 10 to 14, was associated with two regions for which nonfeed costs in model I were near the high and low values for the 20 regions. The "correct" values for these nonfeed costs are difficult to determine but it is evident that any refinement in the model must include more accurate data on this cost item.

\section{MODEL III}

Model III is designed to determine the effect of differences in feeding efficiency among regions on the location of cattle feeding. Comparisons of results from model III and model II prove useful since both models are based on equal nonfeed costs for a given feeding activity. They differ as to the feeding efficiency index by region as shown in table 23. For model II this index varies between 92 and 110, whereas for model III the feeding efficiency level was set at the United States assumed average of 100 for all regions. This implies that the amount of concentrate and roughage fed per pound of gain is equal for a given feeding activity in each region. The detailed pattern of location of feeding and shipments of meat and intermediate products under model III are given in table 24 . For this analysis, attention will be centered on changes in location of marketings from model II to model III, as shown in table 23 . 
TABLE 23

Regional Marketings Under Model III and Actual 1958 Marketings and Change from Model II to Model III With Equal Regional Feeding Efficiency

\begin{tabular}{|c|c|c|c|c|c|}
\hline \multirow{3}{*}{ Region } & \multirow{2}{*}{\multicolumn{2}{|c|}{ Marketings of fed cattle under:* }} & \multicolumn{3}{|c|}{ Change from Model II in: } \\
\hline & & & \multirow{2}{*}{$\begin{array}{l}\text { Feeding } \\
\text { efficiency } \\
\text { index } †\end{array}$} & \multicolumn{2}{|c|}{ Number of head marketed $\ddagger$} \\
\hline & Actual & Model III & & Absolute & Percentage \\
\hline & thousand head & thousand head & $\begin{array}{c}\text { percentage } \\
\text { points }\end{array}$ & thousand & percent \\
\hline \multicolumn{6}{|l|}{ West } \\
\hline $1 \ldots \ldots \ldots \ldots \ldots \ldots \ldots$ & 253 & 0 & -10 & & \\
\hline $2 \ldots \ldots \ldots$ & $\mathbf{5 7 1}$ & 0 & -6 & & \\
\hline $3 \ldots \ldots$ & $\mathbf{5 7 0}$ & 45 & -6 & -482 & -91 \\
\hline $4 \ldots \ldots \ldots \ldots$ & 38 & 55 & -6 & $-\quad 37$ & -40 \\
\hline $5 \ldots$ & 280 & 0 & -1 & - & -100 \\
\hline $6 \ldots \ldots \ldots \ldots$ & 400 & 499 & +1 & +330 & +195 \\
\hline $7 \ldots \ldots \ldots \ldots$ & 175 & 0 & -10 & & \\
\hline $8 \ldots \ldots \ldots \ldots$ & 648 & 724 & +8 & $+\quad 427$ & +144 \\
\hline $9 \ldots \ldots \ldots \ldots \ldots \ldots \ldots$ & 68 & 257 & +1 & 0 & 0 \\
\hline Total ..... & 3,003 & 1,580 & & +237 & +18 \\
\hline \multicolumn{6}{|l|}{ Northern Plains } \\
\hline $10 \ldots \ldots \ldots \ldots$ & 541 & 1,743 & -10 & $-1,535$ & -47 \\
\hline $11 \ldots \ldots \ldots \ldots \ldots \ldots \ldots$ & 1,556 & 4,199 & +8 & $+4,199$ & $\ldots \S$ \\
\hline Total. . & 2,097 & 5,942 & & $+2,664$ & +51 \\
\hline \multicolumn{6}{|l|}{ Southern Plains } \\
\hline $12 \ldots \ldots \ldots \ldots \ldots \ldots \ldots$ & 400 & 514 & +1 & -815 & -61 \\
\hline \multicolumn{6}{|l|}{ Corn Belt and Lake States } \\
\hline $13 \ldots \ldots \ldots \ldots \ldots \ldots \ldots \ldots$ & 681 & 1,373 & -3 & +91 & +7 \\
\hline $14 \ldots \ldots \ldots \ldots \ldots \ldots \ldots$ & 3,917 & 1,476 & -3 & $-1,631$ & -52 \\
\hline $16 \ldots \ldots \ldots \ldots \ldots \ldots \ldots$ & 745 & 302 & -3 & -276 & -48 \\
\hline Total ..... & 5,343 & 3,151 & & $-1,816$ & -37 \\
\hline \multicolumn{6}{|l|}{ Northeast } \\
\hline $18 \ldots \ldots \ldots \ldots \ldots \ldots \ldots$ & 134 & 88 & -3 & -261 & -75 \\
\hline \multicolumn{6}{|l|}{ South } \\
\hline$\ldots \ldots \ldots \ldots$ & 83 & 0 & +9 & & \\
\hline $17 \ldots \ldots \ldots \ldots \ldots \ldots \ldots$ & 73 & 0 & +9 & & \\
\hline $19 \ldots \ldots \ldots \ldots \ldots \ldots \ldots \ldots$ & 96 . & 0 & +9 & & \\
\hline $20 \ldots \ldots \ldots \ldots \ldots \ldots \ldots$ & 37 & 0 & +9 & & \\
\hline Total .... & 289 & 0 & & & \\
\hline Total. . & 11,266 & 11,275 & & $9 \|$ & $\ldots$ \\
\hline
\end{tabular}

* See table 15 for estimated actual marketings and table 24 for model III results.

$\dagger$ Under model III the feed conversion efficiency was set equal to the United States average for all regions, as compared with differences in feeding activities among regions as shown in appendix table C.

$\ddagger$ No feeding was included in either model I or II for regions $1,2,7,15,17,19$, and 20.

$\$$ Percentage increase infinite since no feeding was included under model II.

The increase from model II to model III is due to an increase in feeder cattle availability in region 12 introduced for computational purposes.

I Less than 0.5 per cent.

An increase in the feeding efficiency index from model II was made in nine regions in model III. In four of these regions, no feeding was done under either program. For three regions (8, 6,11 ), the higher feeding efficiency index was associated with increased feeding; for one region (9), no change in feeding took place; and for the other reregion (12), a decrease in feeding took place. The last mentioned result is due to the relatively greater increase in feeding efficiency in region 11 . Thus, in an interregional model, the importance of relative levels of costs is emphasized. In this model where intermediate products 


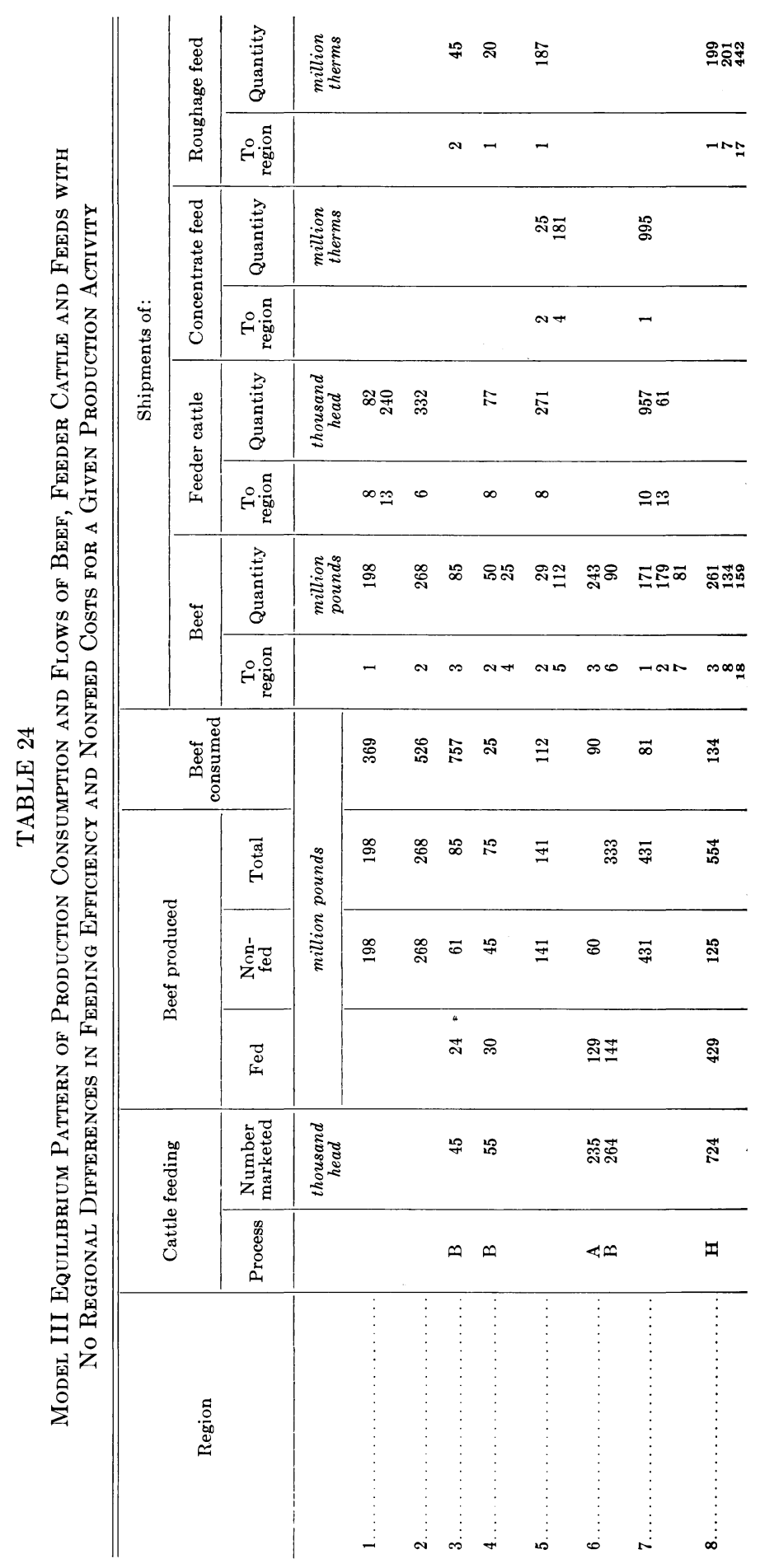




\begin{tabular}{|c|c|c|c|c|c|c|c|c|c|}
\hline & & & 용요 & & $\stackrel{\infty}{=}$ & & 牙 & $\stackrel{\infty}{=}$ & 总 \\
\hline & & & 믐요 & & $=$ & & $\stackrel{9}{-}$ & 9 & \\
\hline & 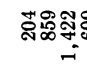 & 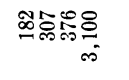 & & $\begin{array}{l}\text { \&్: } \\
\text { i }\end{array}$ & 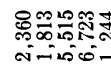 & & $\begin{array}{l}\text { 总 } \\
\text { if } \\
\text { if }\end{array}$ & & 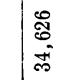 \\
\hline & $-\infty \infty$ & 00어몽 & & 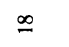 & $\stackrel{2}{2}=\infty 096$ & & $\stackrel{\infty}{-}$ & & \\
\hline & & & 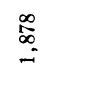 & & & $\stackrel{\substack{\mathfrak{N} \\
-}}{=}$ & 总 & 왕 잉 & 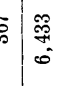 \\
\hline & & & $=$ & & & $=$ & \pm & $\cong \simeq$ & Q \\
\hline 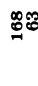 & \&: & 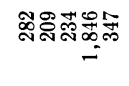 & 怘 䟢 & 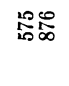 & న్ఞ్ㅀ & ఫ్రీస్ & 范范 & ¿ 용 : & : \\
\hline$\infty$ & $9 \underline{\infty}$ & $= \pm ニ \infty 9$ & $\simeq 98$ & 9 & \pm 0 & 오요 & $\mathscr{0}=$ & $\stackrel{\infty}{\circ}$ \& & s \\
\hline $\mathscr{8}$ & 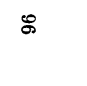 & $\stackrel{\Xi}{్}$ & $\underset{\infty}{\infty}$ & : & $\stackrel{\&}{\stackrel{\&}{二}}$ & 융 & 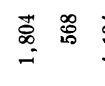 & $\begin{array}{ll}\text { 范 } \\
\vec{\sigma}\end{array}$ & 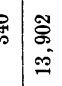 \\
\hline $\bar{x}$ & $\stackrel{\substack{\circ \\
\hdashline}}{-}$ & $\begin{array}{l}\infty \\
\frac{\infty}{\sigma} \\
i\end{array}$ & $\stackrel{\mathscr{8}}{=}$ & $\stackrel{5}{=}$ & : & 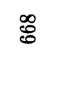 & \& 范 & \& 융 욤 & 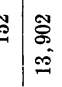 \\
\hline$\&$ & : & $\underset{\$}{\$}$ & 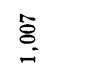 & $\stackrel{8}{\circ}$ & $\stackrel{80}{80}$ & 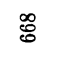 & 年 & $\frac{\infty}{\infty}$ 옳 욤 & 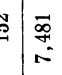 \\
\hline פ: & : & 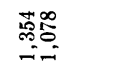 & $\underset{\sim}{\mathscr{D}}$ & 퓨뮤 & ळ & & $\stackrel{\circ}{\circ}$ & $\stackrel{\infty}{\sim}$ & $\begin{array}{l}\vec{F} \\
\text { ఫ్ }\end{array}$ \\
\hline & 䙲 & 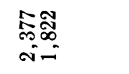 & $\frac{\pi}{i s}$ & 象店 & 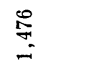 & & ซ్ఠ & $\infty$ & : \\
\hline $4 m$ & 国压 & 国理 & $\infty$ & 国安 & $\infty$ & & $\infty$ & $\infty$ & \\
\hline क & $\stackrel{\vdots}{\varrho}$ & $=$ & $\stackrel{\vdots}{\simeq}$ & $\dot{\infty}$ & $\dot{\vdots}$ & $\begin{array}{c}\vdots \\
\stackrel{a}{a}\end{array}$ & $\underline{\vdots}$ & 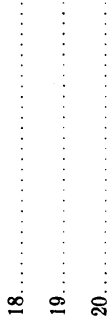 & : \\
\hline
\end{tabular}


of feeds and feeder cattle are involved, shifts in any one region set off a chain reaction, the quantitative nature of which are difficult to specify without rerunning the problem. But the importance of considering the effect of such variables as regional supplies of intermediate products, nonfeed costs, and feeding efficiency is evident.

A decrease in the feeding efficiency index from model II was made for eleven regions in model III. In three of these regions, no feeding was done under either program. The lower feeding efficiency index was associated with reduced feeding in seven of the regions $(3,4,5,10,14,16,18)$, and increased feeding in one region (13). It is important to note that the reduction in the feeding efficiency index of three points in regions $13,14,16$, and 18 is associated with wide differences in both the absolute and percentage changes in numbers marketed. The change in any given region depends not only on the magnitude of its change but on the interrelated changes in other regions.

The assumption of equal feeding efficiency by region is probably not a realistic one but it does allow analysis of change in location due to this factor. In addition to the changes in location discussed above, there are interesting changes in the level of shipment of feeder cattle, feed concentrates and roughage. As might be expected, if there are no regional advantages in feeding efficiency, there is less reason for shipments of intermediate products. This is clearly indicated in the comparison between model II and III. Under model II, total interregional shipments of feed concentrates equal 36,870 million therms of which 33,482 million therms are shipments to meet the regional deficits specified in the problem (see table 19). Shipments of concentrates for cattle feeding equal 3,388 million therms, and represent 9.2 per cent of total shipments. Under model III, total shipments equal 34,626 million therms, with shipments for cattle feeding equal to 1,144 million therms, or 3.3 per cent of the total shipments.

A similar situation holds for roughage shipments. Under model II, total roughage shipments equal 5,596 million therms, of which 3,253 million therms are shipments to meet regional deficits. Shipments for cattle feeding equal 2,343 million therms, and represent 42 per cent of total shipments. Under model III, no shipments are included for purposes of cattle feeding, with each producing region being self-sufficient in roughage supplies.

In summary, the major shifts in feeding location between models II and III include the following: (1) Increased feeding in the Western region, with decreased feeding in Southern California being more than offset by increases in the Mountain States; (2) increased feeding in the Northern Plains, with decreased feeding in region 10 being much more than offset by the introduction of feeding in region 11 , due to a major shift in feeding efficiency indexes of these two regions; (3) decreased feeding in the Southern Plains (region 12) in spite of an increase in the feeding efficiency index. This is associated with the change in region 11 ; (4) decreased feeding in the Corn Belt and Lake States, associated with a decreased feeding efficiency index; and (5) a similar decrease in the Northeast associated with a decreased feeding efficiency index.

The measure of the degree of inefficiency in the "actual" location of feeding as compared with model III indicates an index of 55 , which is lower than that for model II (58) but higher than for model I (45). If one were to argue that the actual 1958 location were in fact efficient, the index would then indicate the relative accuracy of the specification of the problem in the several models. On this basis, model II would appear to be the best representation. On the basis of experimental evidence used to derive the production function, it appears that regional dif- 
TABLE 25

Regional Marketings Under Model IV and Actual 1958 Marketings and Change from Model II to Model IV Associated With Change in the Specification of Regional Consumption of Fed and Nonfed Beef

\begin{tabular}{|c|c|c|c|c|c|c|}
\hline \multirow{2}{*}{ Region } & \multicolumn{4}{|c|}{ Marketings of fed cattle:* } & \multicolumn{2}{|c|}{$\begin{array}{l}\text { Beef from feedlot market- } \\
\text { ings as a percentage of } \\
\text { total consumption }\end{array}$} \\
\hline & Actual & Model IV & Model II & $\begin{array}{l}\text { Change from } \\
\text { Model II to } \\
\text { Model IV }\end{array}$ & Model II $\dagger$ & $\begin{array}{l}\text { Specification } \\
\text { change from } \\
\text { Model II to } \\
\text { Model IV }\end{array}$ \\
\hline & \multicolumn{4}{|c|}{ thousand head } & per cent & $\begin{array}{l}\text { percentage } \\
\text { points }\end{array}$ \\
\hline \multicolumn{7}{|l|}{ West } \\
\hline 1. & 253 & 0 & 0 & 0 & 0 & +46 \\
\hline 2. & 571 & 0 & 0 & 0 & 7 & +39 \\
\hline 3. & 570 & 128 & 527 & $-\quad 399$ & 74 & -28 \\
\hline 4 . & 38 & 8 & 92 & -84 & 46 & 0 \\
\hline 5 . . & 280 & 91 & 1 & +90 & 1 & +45 \\
\hline 6 . & 400 & 390 & 169 & +221 & 46 & 0 \\
\hline $7 \ldots$ & 175 & 323 & 0 & +323 & 0 & +46 \\
\hline 8. & 648 & 644 & 297 & +347 & 46 & 0 \\
\hline $9 \ldots \ldots$ & 68 & 164 & 257 & $-\quad 93$ & 46 & 0 \\
\hline Total.... & 3,003 & 1,748 & 1,343 & +405 & & \\
\hline \multicolumn{7}{|l|}{ Northern Plains } \\
\hline $10 \ldots \ldots \ldots$ & 541 & 2,211 & 3,278 & $-1,067$ & 46 & 0 \\
\hline $11 \ldots \ldots \ldots \ldots$ & 1,556 & 1,559 & 0 & $+1,559$ & 0 & +46 \\
\hline Total...... & 2,097 & 3,770 & 3,278 & +492 & & \\
\hline \multicolumn{7}{|l|}{ Southern Plains } \\
\hline $12 \ldots \ldots \ldots \ldots$ & 400 & 1,550 & 1,329 & +221 & 46 & 0 \\
\hline \multicolumn{7}{|c|}{$\begin{array}{l}\text { Corn Belt and Lake } \\
\text { States }\end{array}$} \\
\hline $13 \ldots \ldots \ldots \ldots$ & 681 & 1,442 & 1,282 & +160 & 46 & 0 \\
\hline$\ldots \ldots \ldots$ & 3,917 & 1,955 & 3,107 & $-1,152$ & 48 & -2 \\
\hline $16 \ldots$ & 745 & 578 & 578 & 0 & 76 & -30 \\
\hline Total... & 5,343 & 3,975 & 4,967 & -992 & & \\
\hline \multicolumn{7}{|l|}{ Northeast } \\
\hline $18 \ldots$ & 134 & 232 & 349 & -117 & 64 & -18 \\
\hline \multicolumn{7}{|l|}{ South } \\
\hline 15 & 83 & 0 & 0 & 0 & 0 & +46 \\
\hline 17. & 73 & 0 & $\mathbf{0}$ & 0 & 4 & +42 \\
\hline $19 \ldots \ldots \ldots \ldots$ & 96 & 0 & 0 & 0 & 23 & +23 \\
\hline $20 \ldots$ & 37 & 0 & 0 & 0 & 22 & +24 \\
\hline Total...... & 289 & 0 & 0 & & & \\
\hline Total... & 11,266 & 11,275 & 11,266 & + & 46 & 0 \\
\hline
\end{tabular}

* See table 15 for estimated actual marketings; table 26 for model IV results; and table 22 for model II results.

t Shipment pattern for all beef shipments is based on data given in table 22. The allocation between fed and nonfed beef, which is arbitrary for some regions, was made as follows: (1) Regions in which production plus nonfed beef supply exceeds consumption, fed beef assumed to equal 46 per cent of regional consumption (regions $4,5,6,8,9,10,12,13,14$ ); exceeds consumption, fed beef assumed to equal 46 per cent of regional consumption (regions $4,5,6,8,9,10,12,13,14$ ); for regions in which production plus nonfed beef supply less than consumption, shipments from surplus regions are residuals of fed or nonfed beef (regions $3,16,18)$; for regions in which no feeding is done and are supplied by nonfel beef from nonfeeding
areas, nonbeef supplies equal 100 per cent of consumption (regions $1,7,11,15$ ); and regions in which no feeding is done and areas, nonbeef supplies equal 100 per cent of consumption (regions $1,7,11,15$ ); and regions in which no feeding is done and
are supplied by regions in which feeding may or may not take place, shipments from surplus regions are residuals of fed or nonfed beef (regions 2, 17, 19, 20).

$\ddagger$ The increase from model II to model IV is due to an increase in feeder cattle availability in region 12 introduced for computational purposes. 


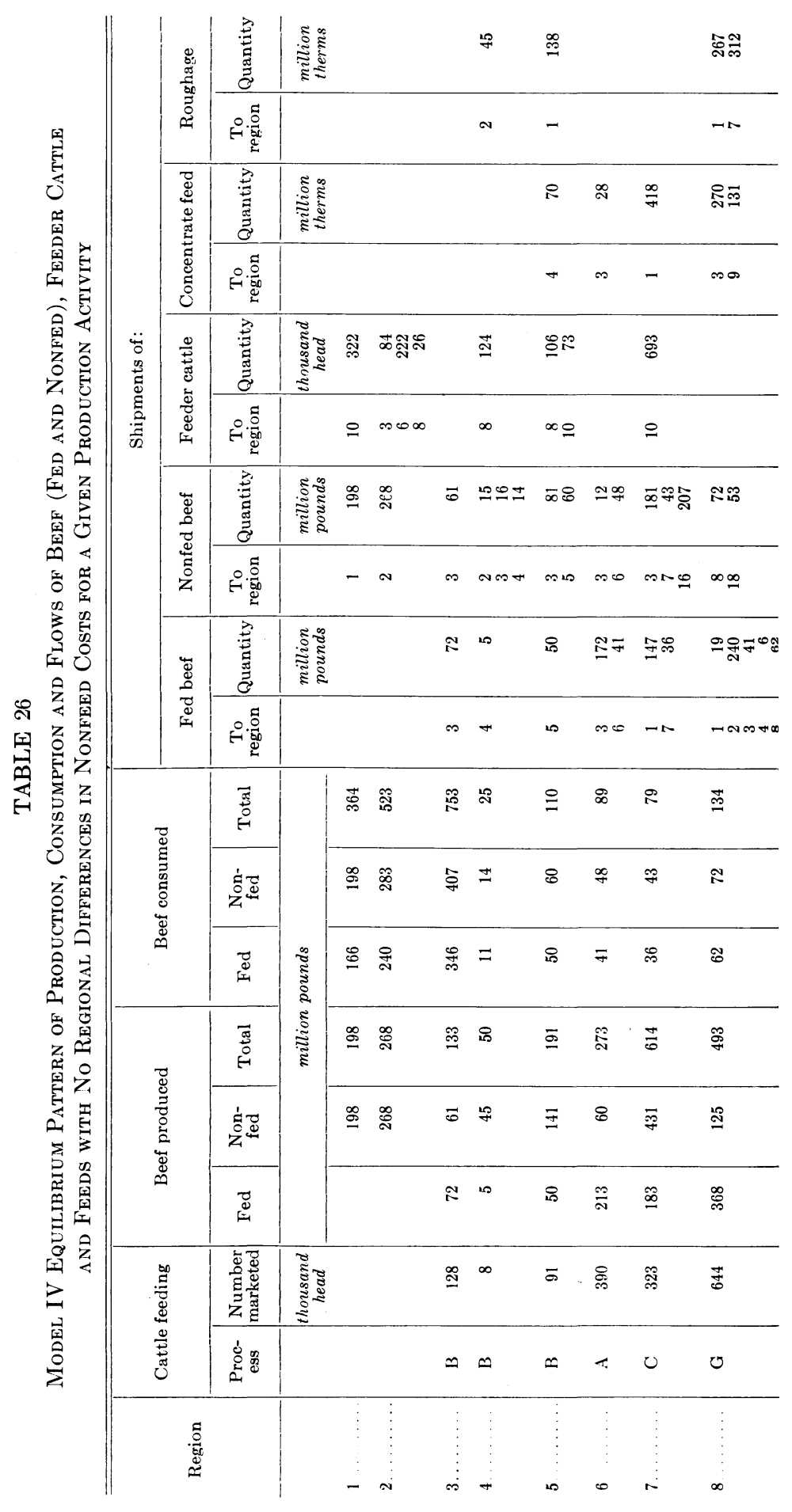




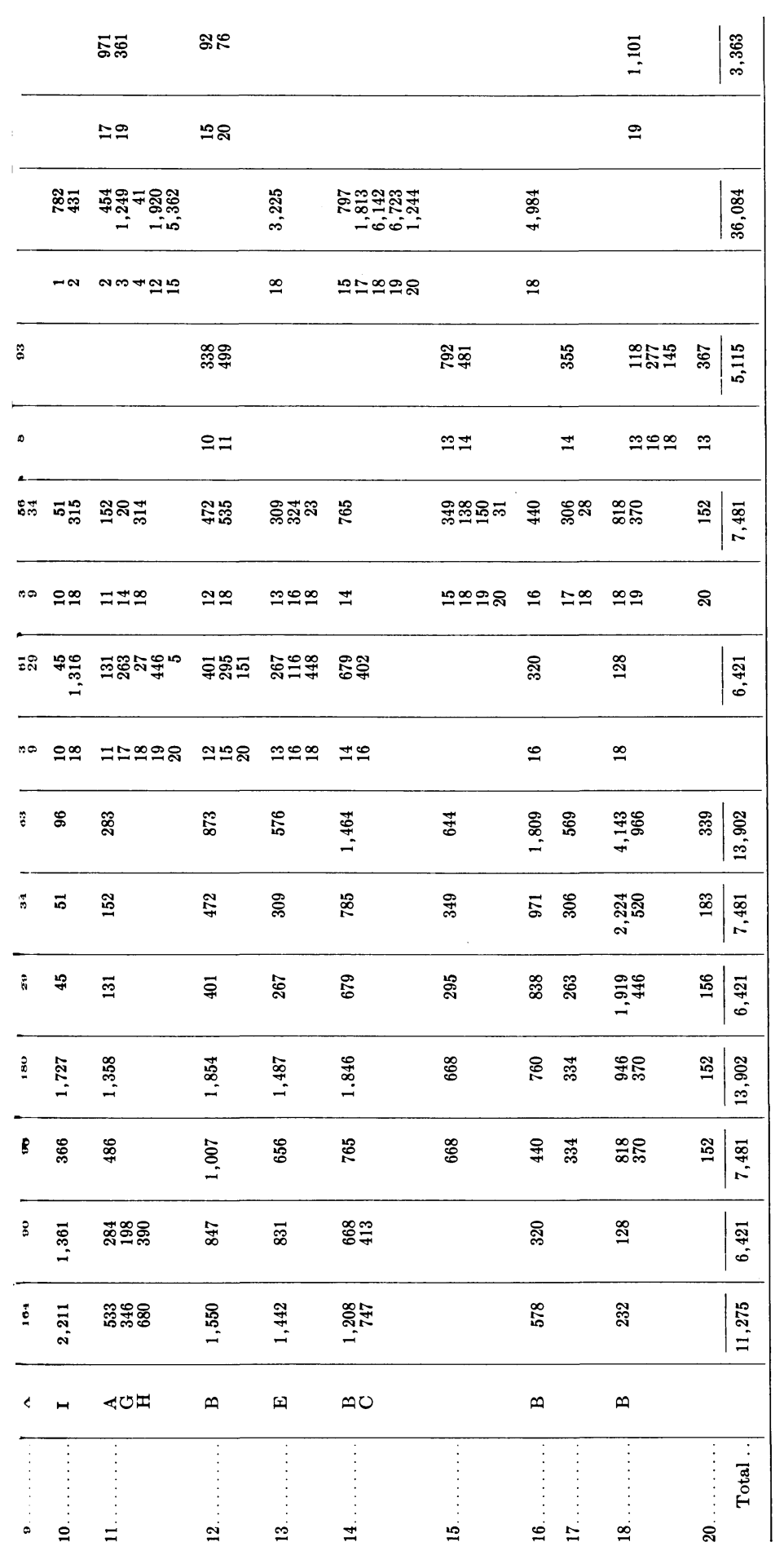


ferences in feeding efficiency do exist. Thus, although the exact level of feeding efficiency among regions may be subject to considerable error, the argument is made that models I and II probably are better representations of relevant feeding conditions than is model III.

As to the validity of models I and II, in the short run, nonfeed costs associated with fixed costs of buildings are not a relevant consideration, but those associated with the variable items such as labor are relevant. Model II results may be more representative of the short-run situation whereas model I may represent a long-run equilibrium, assuming cost levels are accurate. There is some difficulty in the treatment of fed and nonfed beef which is considered to be identical under these three models. An alternative specification is given next in model IV.

\section{MODEL IV}

This model corresponds to model II in the specifications that nonfeed costs are equal among regions for a given feeding activity, and that feeding efficiency differs among regions. It introduces an additional specification; namely, that the proportion of total consumption that is fed beef is the same in all regions. This modification appeared to warrant consideration since in the optimum solution of model II, the percentage of regional consumption that was fed beef ranged from zero in regions $1,7,11$, and 15 , to 76 per cent in region 16. The proportion of consumption that is fed beef in model II is shown in table 25 for each of the 20 regions, with the method used in allocating shipments explained in a footnote. In model IV the proportion that is fed beef was set equal to 46 per cent of consumption in each region. Thus, where some arbitrary allocation of shipments between fed and nonfed beef was possible in model II, a level of 46 per cent was used to provide as rigorous a test as possible as to the effect of forcing all regions to have con- sumption composed of the same per cent of fed beef.

Determination of the shipment patterns under model IV was estimated separately for nonfed beef and for fed beef. With given levels of regional availability and consumption of nonfed beef, this aspect was treated as a transportation problem using the relevant transfer costs for beef. (See Dorfman et al., 1958, p. 106.) The spatial equilibrium model was then used to obtain production and shipment patterns for fed beef and related shipments of feeder cattle and feeds. The shipment patterns are summarized in table 26 for fed and nonfed beef and for feeders, concentrates, and hay.

Under model II, there is a direct correspondence between regions in which no feeding is done and those with belowaverage proportion of fed beef consumption. Of the nine regions with low fed beef consumption in model II (regions $1,2,5,7,11,15,17,19,20$ ), there is no feeding in eight and only 1,000 head fed in region 5 .

Under model IV, feeding was done in 14 regions as opposed to 12 in the previous three models. However, feeding is not introduced in any of the models in regions 1, 2, 15, 17, 19 and 20. An increased number of cattle are fed in the total Western region. Self-sufficiency is maintained in fed-beef supplies, but nonfed beef is now shipped out of the region with the higher production level of fed beef. Correspondingly, fewer animals are fed in all other regions.

Within the Western region, feeding was introduced or increased in two regions (5 and 7) associated with the higher specification for fed beef, and decreased in region 3 associated with the lower specification for fed beef. In two regions ( 1 and 2 ), feeding was not introduced even with more favorable conditions. In the remaining four regions in which the specification was unchanged, feeding increased in two (6, 8 ) and decreased in the other two (4 and 9). As has been found previously, 
this result is due to the interrelations in factor shipments and also in this case to the somewhat arbitrary allocation of shipments in model II between fed and nonfed beef.

In the other regions, feeding was introduced in region 11 associated with the higher demand specification for fed beef. For regions with a lower specification for fed beef, feeding was decreased in two regions (14 and 18) and remained unchanged in region 16 in three regions associated with the lower specification for fed beef. In four regions $(15,17,19$, and 20$)$, no feeding was introduced even with the more favorable demand specification. In three regions in which the specification for fed beef remained essentially unchanged, feeding increased in two regions (12 and 13) and decreased in region 10.

In general, the results of this analysis are consistent with the expectation that an increase (decrease) in the specification of consumption that is fed beef would result in an increase (decrease) in beef production. The location of feeding in model IV more closely approximates that for 1958 than does model II, which may be an indication of the importance of this specification for the demand for beef. The measure of inefficiency in the "actual" location of feeding for model IV equals 65 as compared to 58 for model II.

Results from this analysis would tend tc support the view that in spatial equilibrium models, it is important to attempt to specify the demand and supply of beef more closely than to assume that beef is a homogeneous item. The model should differentiate between a good or choice grade animal marketed from the feedlot and an animal culled from the dairy herd. Lack of data, however, make any refined specification superfluous. The type of adjustment attempted in model IV appears to be warranted, and the results caution the reader as to the possible limitations of the previous models. Further improvement might be introduced with separate demand func- tions for the various grades of beef if data should be made available and further refinement of the demand interrelationships among various kinds of meat, by region.

\section{IMPUTED REGIONAL FACTOR PRICES}

One of the properties of linear programming problems is that the dual solution provides imputed prices of factors consistent with the equilibrium flows. The imputed prices for feed concentrates and roughages are in terms of dollars per 1,000 therms and relate to prices at the feedlot location. To compare regional prices received by farmers with the imputed prices, two adjustments were necessary. First, the concentrate price was converted to a price per bushel of corn by multiplying the price per therms by the number of therms per bushel (44.86 therms). Similarly, the imputed price for roughage was converted to a price per ton of baled alfalfa hay by multiplying the price per therm by the number of therms per ton ( 812 therms). The second adjustment was to deduct the withinregion transportation cost from the imputed price at the feedlot location to obtain the price at the feed producer level. (See figure 2 and related discussion in the text for an explanation of the relevant level of prices.) For corn, this within-region transportation cost is 7 cents per bushel and for alfalfa hay, $\$ 3.20$ per ton. The adjusted imputed prices are shown in table 27 for model I with comparable data on prices received by farmers for corn and alfalfa hay. The level of imputed prices in the other models were comparable to those for model I. For model I, the level of imputed prices in the 20 regions averaged 22 per cent above the price received for corn and 50 per cent above that for alfalfa hay. The difference in the price level is not uniform among regions, however, which raises questions as to the production response by feed producers if such regional prices exist. 


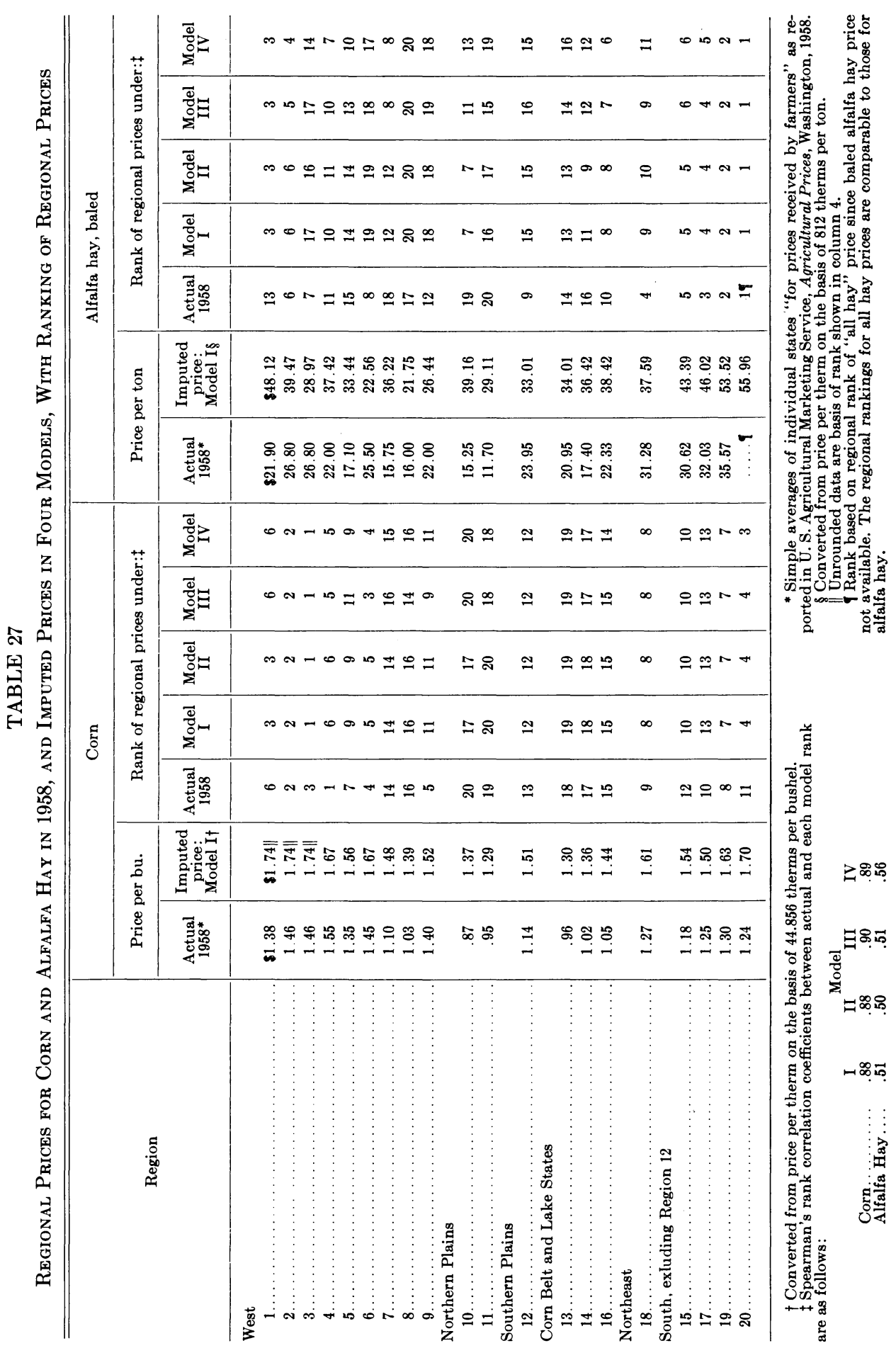


To check the relative level of prices by region, a comparison is made by ranking regions as to the level of actual and imputed prices and performing a rank correlation test. For corn, the coefficient of rank correlation equalled .88 for models I and II, .90 for model III, and .89 for model IV. These results would tend to indicate that the relative regional prices of the models were fairly consistent with actual prices. This is in part due to the fact that 9 of the 20 regions were specified as deficit in feed concentrates and thus prices in these regions would be higher than the supplying regions. The results tend to support the reasonableness of the feed concentrate flows for the entire model. However, for a particular region, such as 10, the imputed price for corn is such that the production response by grain producers would be considerable. This difference between actual and imputed is associated with the large increase in feeding in region 10 , with large inshipments of grain, and thus the high imputed price. The problem reflected here is that the model is a partial equilibrium approach for one segment of the livestock-feed economy. Thus, the equilibrium applies only in a narrow context, and the inferences that may be drawn from the model results are severely limited.

The relative price structure for roughage is less reassuring. The coefficient of rank correlation equals .51 for model I, .50 for model II, .51 for model III, and .56 for model IV. Less accuracy is evident in the basic data for roughage than for concentrate feed, and this may cause some difficulty in these results. Another factor, noted previously, that warrants consideration is that the shipments of roughage in model III are made only to meet specified regional deficits in seven regions. Consider shipments in model III made from region 5
(Utah-Idaho) to region 1 (WashingtonOregon). No feeding is indicated in region 1. The difference in imputed prices between these two regions is $\$ 14.68$ per ton reflecting the rail shipment cost between the central points of the two regions. It is reasonable that shipments are made between these two regions based on shipment patterns for 1954 estimated by McGlothlin (1957, p. 14). The hay movement in the Western region was predominantly by truck. Undoubtedly the rail rates used in this study for shipments between adjacent regions overstate the cost of such shipments if made by truck. Further refinement of the model should include specification of a transfer function for feed that includes truck shipments for that range of shipment distances for which truck shipment costs are lower than for rail shipments.

Prices of feeder cattle are available for 18 regions and provide a basis of comparison for imputed prices in the four models, as shown in table 28. The simple average of these 18 regional prices for stocker and feeder calves of good grade weighing between 500 and 800 pounds equalled $\$ 25.18$ per 100 pounds as compared with an average of $\$ 24.59$ per 100 pounds in the same regions for imputed prices under model I. Thus, the level of imputed and actual prices correspond closely. The relative prices by region were checked by means of the rank correlation test employed for feed grains and hay. The correlation coefficient equalled .57 for model IV, .48 for model III, and .27 for both models I and II. With different feeding locations under the model results than under actual 1958 conditions, it would be expected that imputed feeder cattle prices by region also differ from actual prices as is reflected in the rank correlation coefficients. 


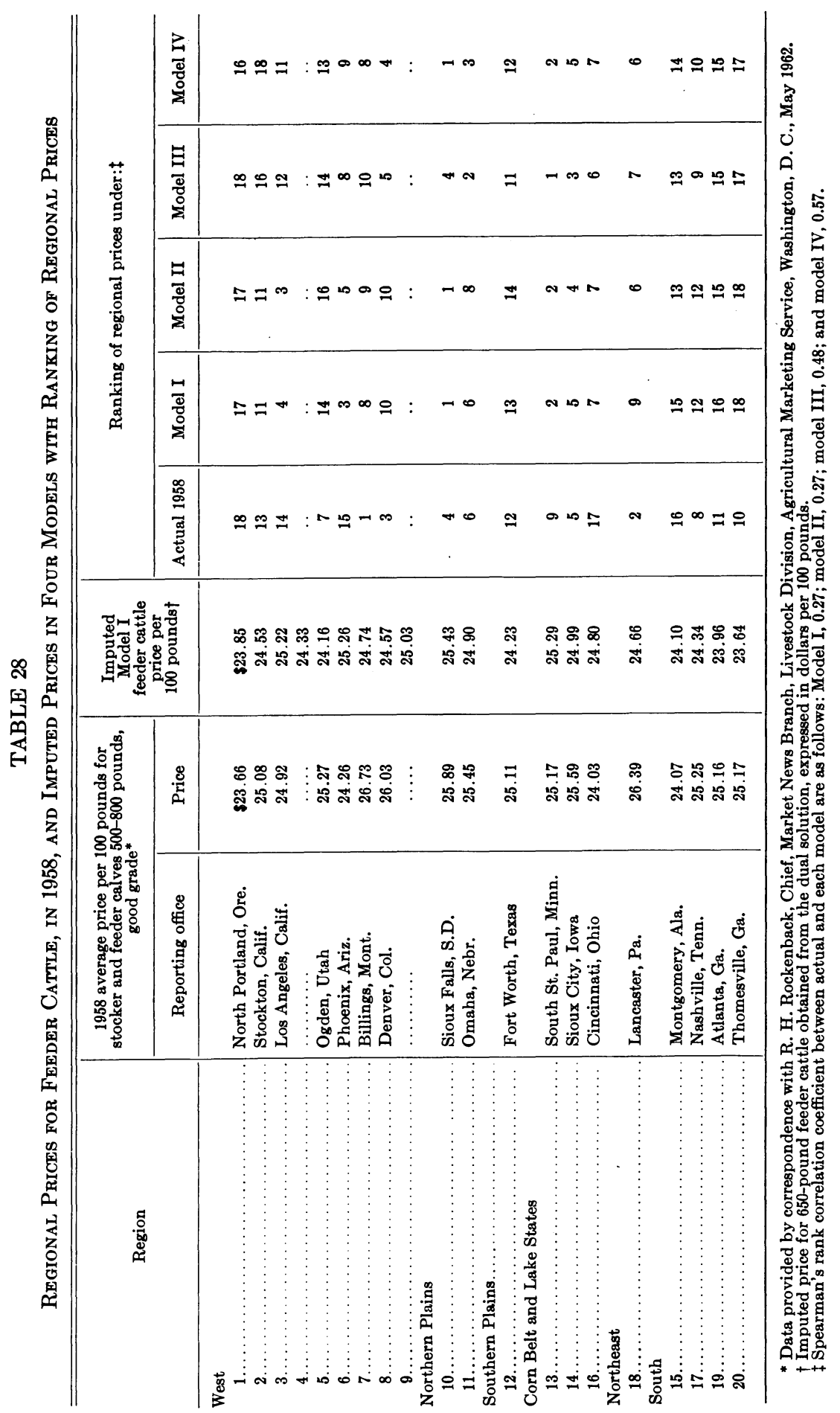




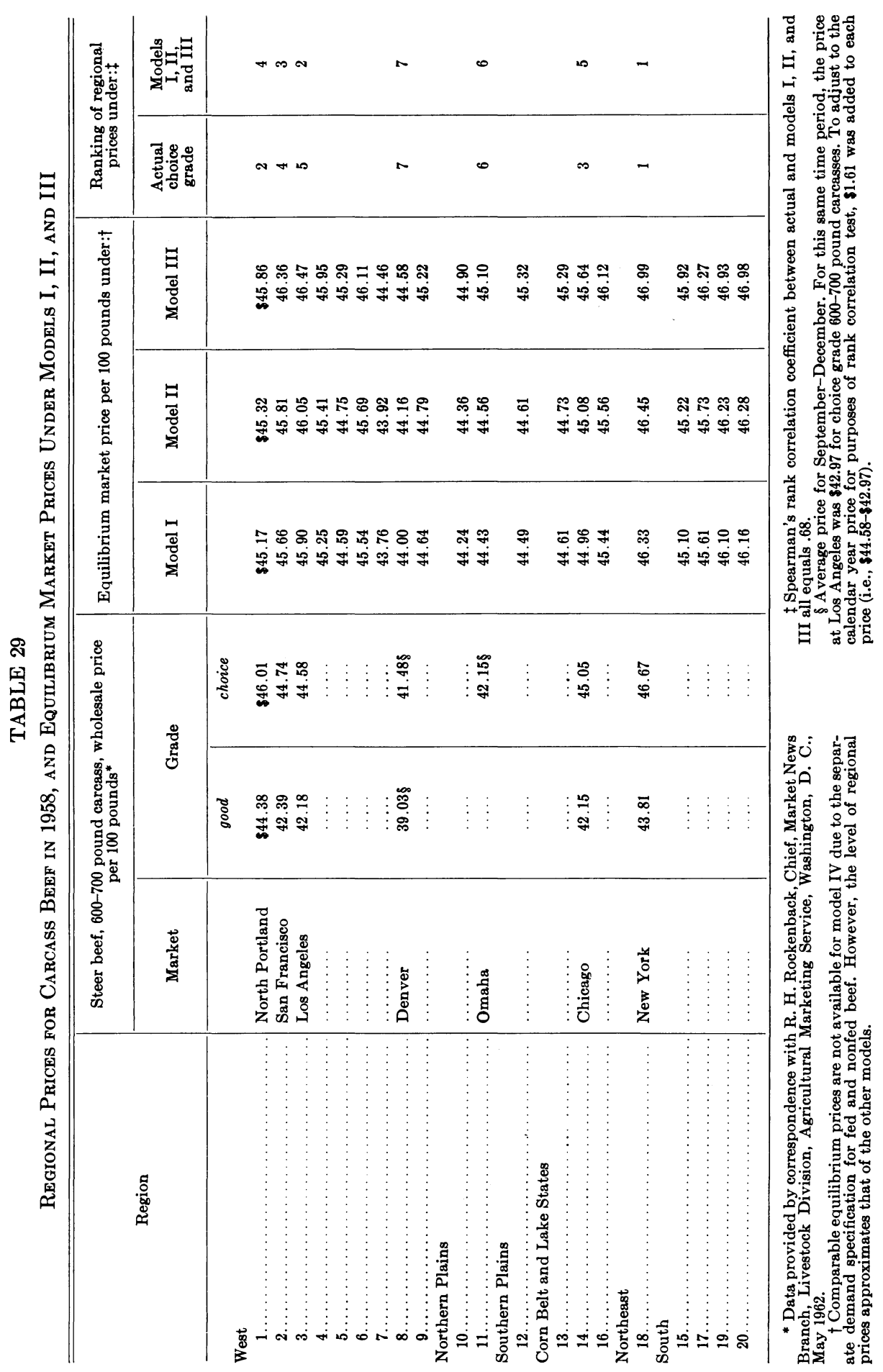




\section{REGIONAL PRICES FOR BEEF AND CONSUMPTION LEVELS}

Prices for carcass beef are available for seven markets for 1958, as indicated in table 29. Price quotations for Denver and Omaha were initiated in September, 1958 and thus data relate only to the September-December average. For the Los Angeles market, the SeptemberDecember average price was $\$ 1.61$ lower than for the calendar year average for 1958. If the prices in Denver and Omaha are raised by this amount $(\$ 1.61)$, the average wholesale price in the seven markets equals $\$ 44.84$ per 100 pounds for choice steer beef carcasses weighing 600-700 pounds, as compared to equilibrium market prices in the same seven regions for model I equal to $\$ 45.21$ per 100 pounds. Prices for models II and III are slightly higher than for model I. Thus, the level of prices of the model is slightly higher than actual prices, although there is a reasonably close correspondence between these price levels. A comparison of the relative prices for carcass meat by region under actual and model I results indicates a rank correlation coefficient of .68 for the seven regions for which data are available. This comparison is limited by lack of data for all regions. However, based on available data, the results do not appear to be unreasonable.

The consumption of beef by region obtained in the model are consistent with the demand function used in the analysis. The accuracy of the consumption levels are difficult to check due to inadequate data on meat shipments among states. An analysis of regional differences in beef consumption is given by Lanahan (1957) based on the 1955 Household Food Consumption Survey. Data relate to the quantity of meats used at home per person in a week during the spring of 1955 . The following regional differences from the United States average consumption level of beef are indicated: West, 130 per cent;
North Central, 121 per cent; South, 68 per cent; and Northeast, 103 per cent.

A comparison of beef consumption levels was made between that in model I and an estimate for 1958 based on the survey data. This estimate was based on the beef consumption per person for the United States of 80.5 pounds, the regional differences noted above, and on July 1, 1958 population levels for the regions used in this study. The comparison is as follows:

\begin{tabular}{|c|c|c|}
\hline & \multicolumn{2}{|c|}{$\begin{array}{l}\text { ESTIMATED BEEF } \\
\text { CONSUMPTION } \\
\text { FOR } 1958 \text { BASED ON : }\end{array}$} \\
\hline & SURVEY & \\
\hline & DATA & MODEL $I$ \\
\hline & \multicolumn{2}{|c|}{ BILLION POUNDS } \\
\hline West (regions 1-9) & 2.6 & 2.1 \\
\hline \multicolumn{3}{|l|}{ North Central (regions } \\
\hline $10,11,13,14,16)$ & 4.9 & 4.3 \\
\hline $\begin{array}{l}\text { South (regions 12, } 15 \text {, } \\
\quad 17,19,20)\end{array}$ & 2.6 & 3.4 \\
\hline Northeast (region 18) & 3.9 & 4.1 \\
\hline United States & 14.0 & 14.0 \\
\hline
\end{tabular}

There is no assurance that the survey data accurately represent regional consumption levels for the year 1958. However, the differences do indicate possible limitations in the demand function employed in the analysis. To illustrate, for the West, consumption in model $I$ is $500,000,000$ pounds less than that estimated from the survey data. This represents approximately 900,000 head of cattle. In each of the four models, cattle feeding took place in the West to satisfy consumption levels. If this result held under a revised demand specification, the level of feeding in this region would approximate actual feeding levels, especially for model IV (see table 26). Information on consumption levels by region would be particularly helpful in further refinement of the model.

\section{EVALUATION OF RESULTS}

There are substantial differences between actual 1958 feedlot marketings by region and those estimated by models I-IV. These models would indicate a large degree of inefficiency in present 
locations as reflected by the index of efficiency which ranges from 45 for model I to 65 for model IV (see table 30 ). This index would equal 100 if model locations corresponded exactly to actual locations. It should be clear that the model is normative in nature, indicating the adjustment pattern in the long run if conditions specified for 1958 were to continue to exist. However, it is also clear that the results obtained depend directly on the accuracy of the basic data and the specifications of the model as to such important variables as the feed conversion efficiency by region, nonfeed costs, transfer costs, feed supplies for beef cattle feeding, and the nature of the demand for beef. The reason for alternative formulations of the problem in the several models was an attempt to determine the shifts in location associated with changes in such key variables as feeding efficiency, nonfeed costs, and the demand for fed and nonfed beef.

Nonfeed costs differ by region under model I and are equal under model II (also under models III and IV). In the short run, operators with fixed plant will continue in production although other regions might offer possibilities of a higher return. Thus, in a comparison of actual and estimated locations, there may be good reason for specifiying these costs as equal among regions. However, in the long run, differences in nonfeed costs must be considered in establishing new locations. It appears important to determine accurately nonfeed costs by region, as was attempted for model I specifications. The accuracy of these data, of course, are subject to limitations, and further work on refinement of the data is always desirable. A comparison of shifts in location due to the changed specification of nonfeed costs, as given in table 21 , provides some insight as to the importance of this variable in the present model.

Feed conversion efficiency by regions is an important consideration as reflected in the results of model II where regional differences are specified as compared with model III for which feeding efficiency is assumed equal for all regions. Possible reasons for differences among regions in feed conversion efficiency include management skills in feeding, the quality of the feed, the type of livestock fed, and weather conditions. In the long run, management skills may be completely mobile. The composition of the ration, however, depends on the feeds produced in the area or feeds that may be transported at a reasonable cost. Further, weather conditions may continue to favor one region over another. The quantitative effect of weather on feeding efficiency is not readily available, although informed sources indicate the adverse effect of extreme cold or heat on the amount of gain with a given feed input. The importance of experimental evidence on feeding efficiency under varying conditions and by regions is evident from this study. The analysis made of feeding efficiency by region in this report indicates that differences do exist, although the particular levels of feed conversion used in models I, II, and IV may be subject to considerable error.

In model IV, the proportion of total consumption that was fed beef is specified as equal for all regions. This model is directly comparable with model II except for this specification. Results indicate that such a specification for beef provides feedlot locations more in line with actual locations, and that consideration should be given this factor in more refined models. However, not all fed beef is a homogeneous product, and the question is raised as to the correct specification of the demand function for beef even apart from the model's basic dependence on a "given" demand function. Here again, further refinement is required especially on regional differences in consumption levels.

The value of imputed prices for feeder cattle, feed concentrates, and hay, obtained from the dual solution, can be compared with actual regional prices as 
TABLE 30

Summary Indicators of Model Results

\begin{tabular}{|c|c|c|c|c|c|}
\hline \multirow{2}{*}{ Model } & \multirow{2}{*}{$\begin{array}{c}\text { Efficiency } \\
\text { index of actual } \\
1958 \text { location }\end{array}$} & \multicolumn{3}{|c|}{$\begin{array}{l}\text { Rank correlation of actual and imputed } \\
\text { priced by region for: }\end{array}$} & \multirow{2}{*}{$\begin{array}{l}\text { Consistency as to } \\
\text { direction of change } \\
\text { between (1) actual } \\
\text { vs. model market- } \\
\text { ings and (2) pro- } \\
\text { portion of cattle } \\
\text { on feed by region } \\
\text { for 1955-57 vs. } \\
1959-62\end{array}$} \\
\hline & & Feeder cattle & Corn & Hay & \\
\hline & index & \multicolumn{3}{|c|}{ correlation coefficient } & number of regions \\
\hline I. . & 45 & .27 & .88 & .51 & $8 / 16$ \\
\hline II...... & 58 & .27 & .88 & .50 & $7 / 16$ \\
\hline III $\ldots \ldots \ldots \ldots$ & 55 & .48 & .90 & .51 & $11 / 16$ \\
\hline IV $\ldots \ldots \ldots \ldots$ & 65 & .57 & .89 & .56 & $10 / 16$ \\
\hline
\end{tabular}

to level and as to regional ranking of prices. The level of feeder cattle prices corresponded closely to model prices, whereas imputed prices for concentrates were 22 per cent higher than actual prices, and imputed prices for roughage averaged 50 per cent higher than actual prices. The regional ranking of actual prices was compared with imputed prices by means of Spearman's rank correlation test. The results, summarized in table 30, indicate higher coefficients in general for models III and IV. The imputed prices for feed concentrates correspond more closely to actual prices than do prices for hay or feeder cattle. The imputed prices for the feed concentrates and roughage depend to some extent on the assumed regional availability for livestock feeding, which were specified as deficits in some regions. Although this model specification appears valid in this partial equilibrium approach, the desirability of a model considering all aspects of the feed-livestock economy is obvious. For feeder cattle, imputed prices reflect feeding locations, and since model locations differed markedly from actual 1958 locations, it is not surprising that there is a low correlation between actual and imputed feeder cattle prices.

Shifts in the location of feeding among regions are indicated in the comparisons given between actual 1958 regional marketings and those under the normative model results. For important feeding areas, the results indicate increased relative importance of feeding in the Northern Plains and Southern Plains and decreased relative importance of feeding in the Corn Belt and Lake States and in the West. How do these results compare with actual changes in the relative importance of cattle feeding areas?

Data are available on the number of cattle on feed on January 1 for the years 1955-62 for 26 important feeding states. These states correspond to those included in the model with the exception of those in the South (regions 15, 17, $19,20) .^{20}$ To obtain an indication of actual shifts in regional importance in cattle feeding, a comparison was made of the proportion of the total number of cattle on feed in the various regions in 1955-57 and 1959-62. The change between these two periods is considered to represent the actual direction of change in regional importance of cattle feeding.

A comparison is given in table 31 between: (1) the actual change in regional importance of cattle feeding between 1955-57 and 1959-62; and (2) the direction of change between actual 1958 mar-

22 The model includes feedlot marketings from the following number of states, by region: West (11), Northern Plains (4), Southern Plains (2), Corn Belt and Lake States (8), Northeast (1 out of 11), and South (12). 


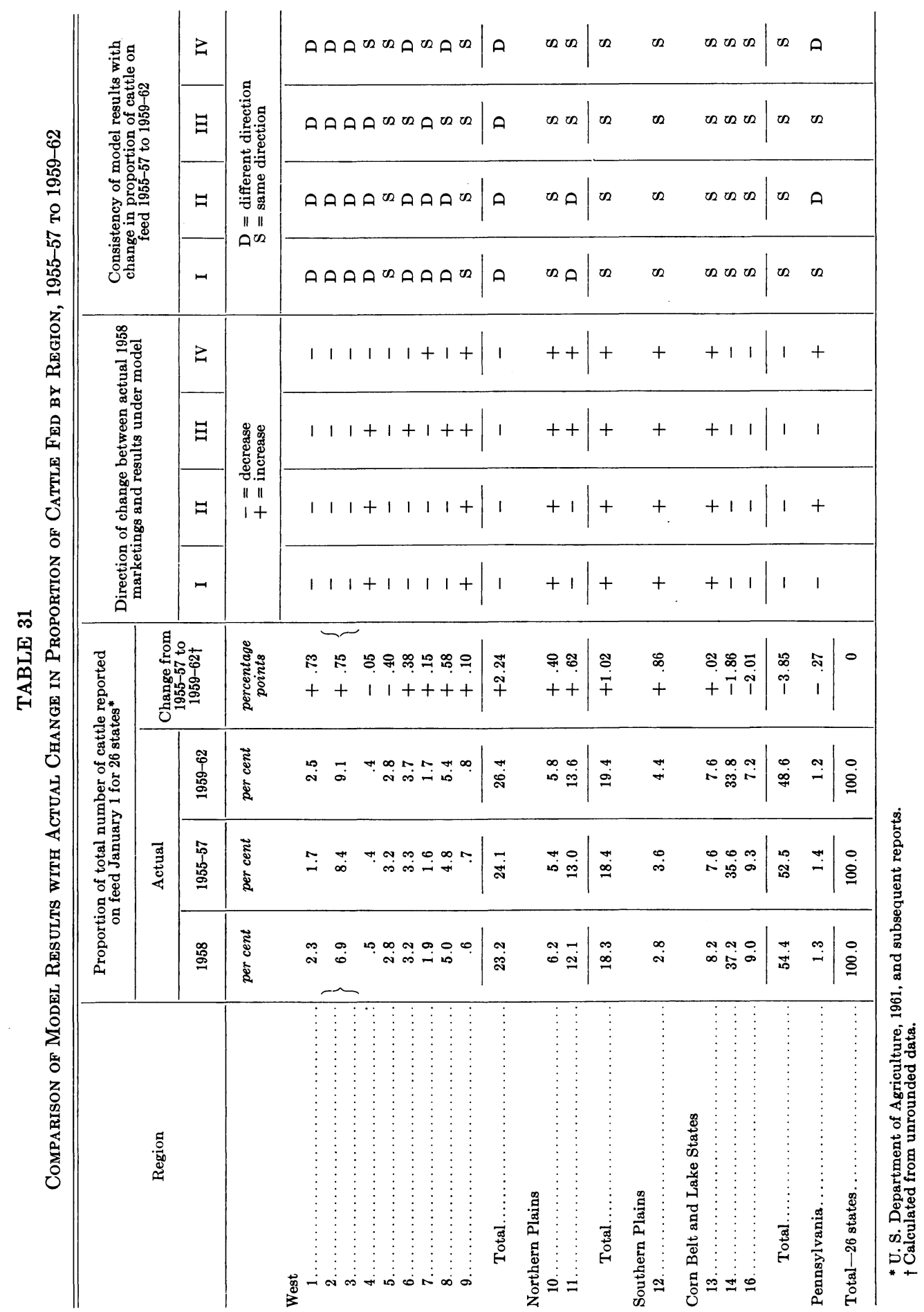




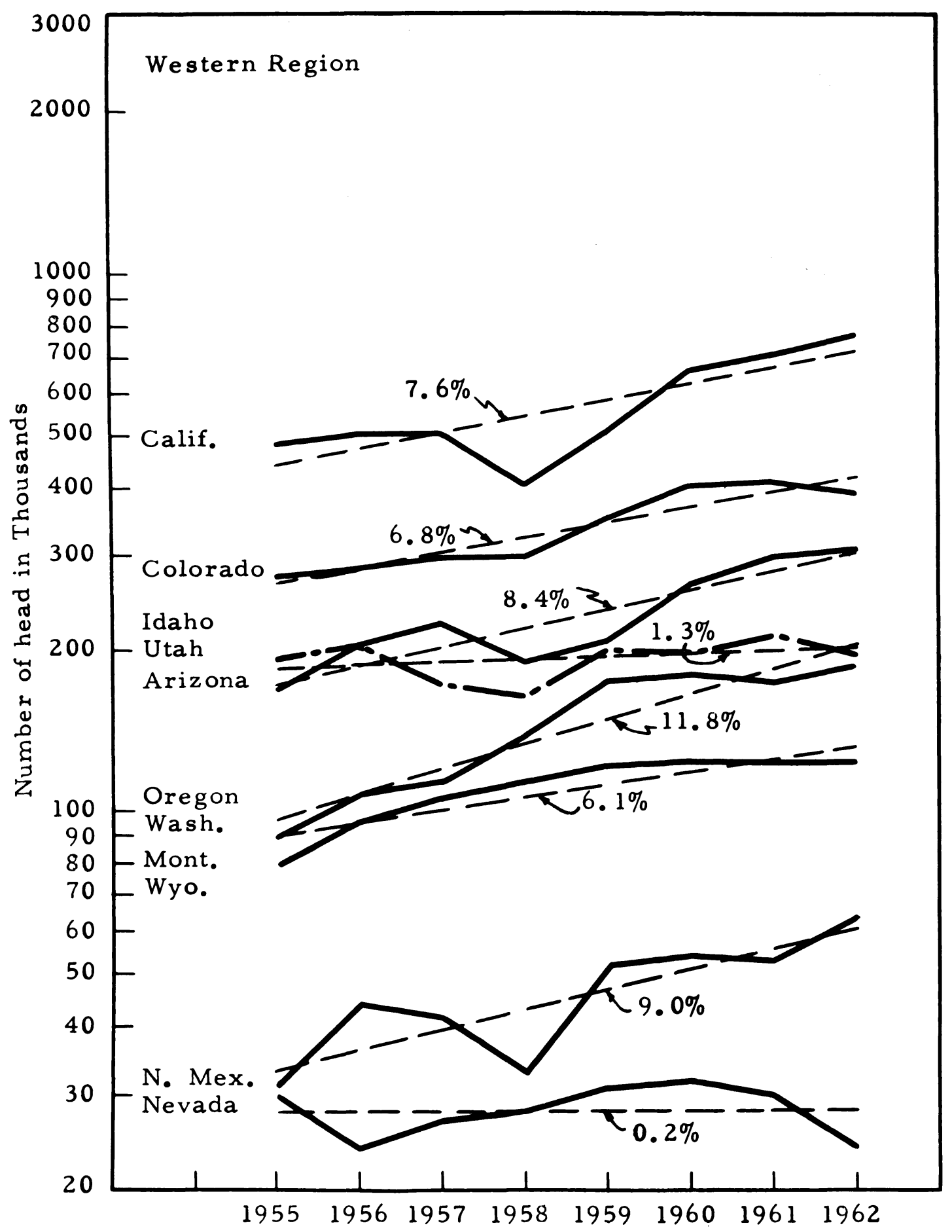

Fig. 7A. Cattle on feed January 1, 1955-62, actual and trned (rate of yearly change) in the western region. 


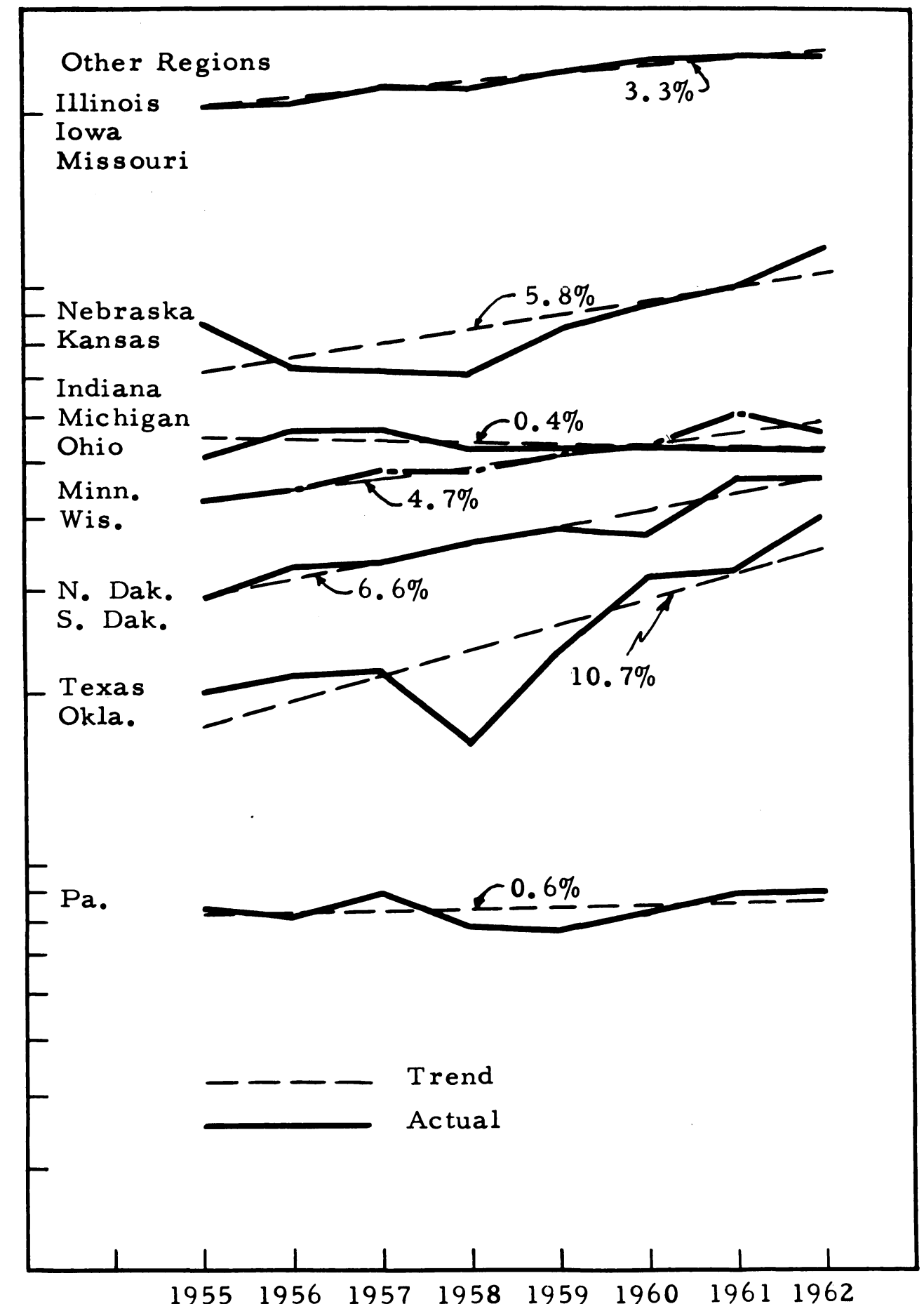

Fig. 7B. Cattle on feed January 1, 1955-62, actual and trend (rate of yearly change) in other regions. 
TABLE 32

Nonfeed Costs in Cents per Head per Day for Model Feedlots Operated at Various Percentages of Maximum Animal Output 3 Lots of Cattle Fed 120 Days

\begin{tabular}{|c|c|c|c|c|c|}
\hline \multirow{2}{*}{ Feedlot designed capacity } & \multicolumn{5}{|c|}{ Per cent of maximum output* } \\
\hline & 100 & 80 & 60 & 40 & 20 \\
\hline 3,760 head. & 7.19 & 7.99 & 9.33 & 11.99 & 19.99 \\
\hline 7,520 head & 6.18 & 6.77 & 7.75 & 9.70 & 15.56 \\
\hline 11,280 head. & 5.92 & 6.46 & 7.35 & 9.13 & 14.46 \\
\hline 15,040 head & 5.75 & 6.25 & 7.08 & 8.73 & 13.70 \\
\hline 22,560 head. & 5.57 & 6.03 & 6.79 & 8.32 & 12.91 \\
\hline
\end{tabular}

* The number of cattle fed for respective feedlots assuming 3 lots per year is as follows:

\begin{tabular}{|c|c|c|c|c|c|}
\hline \multirow{2}{*}{$\begin{array}{l}\text { Feedlot designed } \\
\text { capacity }\end{array}$} & \multicolumn{5}{|c|}{ Per cent of maximum output } \\
\hline & 100 & 80 & 60 & 40 & 20 \\
\hline & \multicolumn{5}{|c|}{ number of head } \\
\hline 3,760 . & 11,280 & 9,024 & 6,768 & 4,512 & 2,256 \\
\hline 7,520 & 22,560 & 18,048 & 13,536 & 9,024 & 4,512 \\
\hline 11,280 & 33,840 & 27,072 & 20,304 & 13,536 & 6,768 \\
\hline 15,040 . & 45,120 & 36,096 & 27,072 & 18,048 & 9,024 \\
\hline 22,560 & 67,680 & 54,144 & 40,608 & 27,072 & 13,536 \\
\hline
\end{tabular}

Source: King, G. A., 1962.

ketings and results under models I-IV. The comparison is in terms of consistency between (1) and (2) above as to direction of change; that is, if both measures indicate an increase (decrease) in feeding, the results are considered consistent. In general, results are consistent for regions other than the West, although results are consistent for regions 5 and 9 for all models, and consistent in one model for regions $4,5,7$, and 8 . The number of regions for which consistent results were obtained for the 16 regions included in this comparison are: 11 for model III, 10 for model IV, 8 for model I, and 7 for model II. Results from this comparison indicate that further study is required as to the possible incorporation of additional factors that affect the location of the feeding industry.

The trend in the number of cattle on feed January 1 for the years 1955-62 is given in figure 7. Trend values are indicated for each region, giving the annual growth in number of cattle on feed for the period. ${ }^{23}$ In general, regions with the higher growth rates correspond to regions for which the proportion of cattle on feed increased between 195557 to $1959-62$.

\section{OTHER FACTORS INFLUENCING FEEDLOT LOCATION}

Three additional considerations in feedlot location should be mentioned briefly. These include: (1) the effect of economies of scale in feedlot operations, (2) the effect of shipping into feeding regions feeder calves weighing 350 pounds, rather than 650-pound animals, to be used as stockers on seasonal range or other inexpensive sources of gain, and (3) the effect of the present location of slaughter plants on feeding locations.

\footnotetext{
${ }^{23}$ An exponential curve was fitted to the data with equation of the following type: $Y=a b^{x}$ where $Y$ is the number of cattle on feed January 1 , and $X$ is the year.
} 

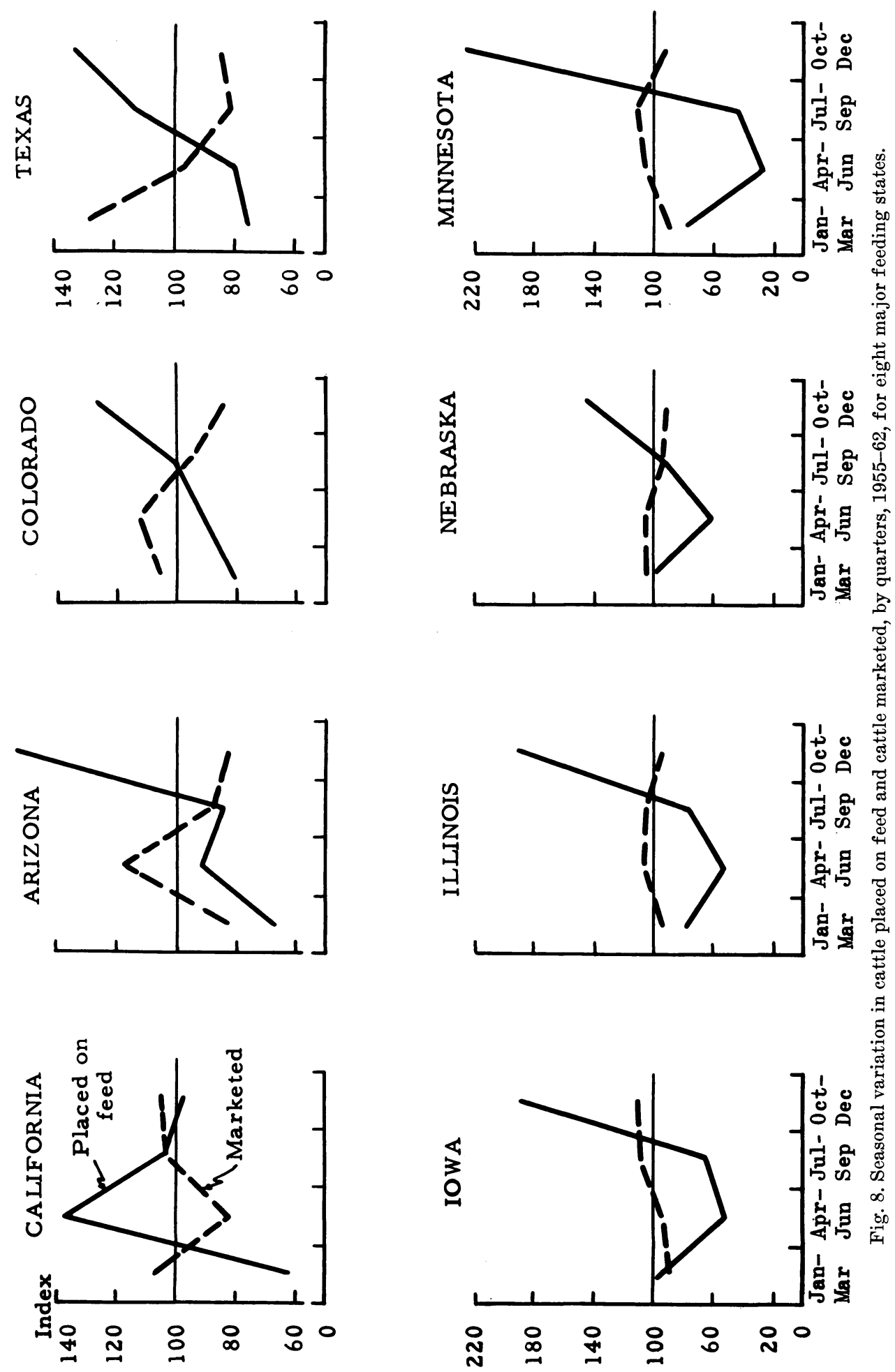


\section{Feedlot Economies of Scale}

Economies of scale in feedlot operations may influence the optimum location pattern. This would be true in the long run only if there were characteristics of a region, such as weather conditions, that favored construction of large-scale feedlots and/or more complete utilization of facilities the year around. Areas in the Southwest would appear to have an advantage in this regard as compared with the Northern Plains.

Nonfeed costs were quantified in a study by King (1962) of large feedlots with designed capacity ranging from 3,760 head to 22,560 head. Costs associated with various annual outputs for the five model feedlots are given in table 32 ; if lots are operated at 80 per cent of maximum annual output per year, the cost equals 8.0 cents per head per day for the feedlot with designed capacity of 3,760 head and 6.2 cents per head per day for the feedlot with 15,040 head designed capacity. This difference of 1.8 cents amounts to $\$ 2.63$ for the 146-day feeding period of feeding activity B. It requires 1.8 feeders to produce 1,000 pounds of beef for this activity, and so the cost per 1,000 pounds of beef for the large lot is $\$ 4.73$ less than for the smaller lot. This accounts for 70 per cent of the value of the partial derivative associated with introducing feeding activity $B$ for region 2 in model I ( $\$ 6.63$ as shown in table 20 ). If feedlots are operated at a higher percentage of capacity in one region than in another due to weather conditions, the cost difference might be even larger.

\section{Seasonality Considerations}

The annual model employed in this study may ignore important seasonal factors affecting location of feedlots. The availability of winter ranges in areas such as California provides the possibility for shipment of feeder calves into the region at weights of 350 500 pounds to take advantage of inexpensive gains before animals are placed in the feedlot. Roughage also is available from sugar beet tops, irrigated pasture, and other roughages for which little alternative use exists. Under this condition, the 650-pound feeders would be located in the region rather than at the region of the breeding herd, as assumed in the model. Transportation costs into the region would relate to 350 -pound animals rather than 650pound feeders.

The seasonal variation in placement of cattle on feed, by quarter, differs significantly between the Midwest and California as shown in figure $8 .^{24}$ (Note that the scale used in the figure for the states of Iowa, Illinois, Nebraska and Minnesota is one-half of that used for the states of California, Arizona, Colorado, and Texas.) In California, cattle placements are at a seasonal peak in the April-June quarter, as cattle are moved from the range or pastures to feedlots. This is in sharp contrast to the other seven states, for which seasonal placements are at a peak in the OctoberDecember quarter. For all regions, inshipments of stocker and feeder cattle are at a peak in the October-December quarter. Marketings show less seasonal variation in the Midwest than in the West and Southern Plains areas shown in figure 8.

A quarterly model of livestock feeding would require data as to availability of feeder cattle by season and weight, as well as data on the seasonal availability of roughage. It does not appear feasible to attempt such a model with the present availability of data. However, ignoring these considerations may explain in part, the results obtained for regions 1,2 , and 3 .

\section{Location of Slaughter Plants}

In this model it is assumed that slaughtering plants are located at the

\footnotetext{
${ }^{24}$ Quarterly indexes were based on data for the years 1955-62 and were calculated using the method outlined by Foote and Fox (1952).
} 
feeding locations, and meat, rather than live animals, is shipped to deficit areas. This implies that these locations would be optimum for cattle slaughtering operations, a point that warrants further consideration. If present location of slaughtering plants had been specified in the model, the location of feeding might well have been changed due to the high cost of shrinkage for longdistance hauls of slaughter weight animals.

Packers want to have a ready supply of fed cattle available for operating their plants at near-capacity levels. This had led packers to purchase cattle for feeding in their own lots or custom feeding the cattle in large commercial feedlots. Scott (1955, p. 48) reports that in 1951-52, 47 per cent of all cattle in California feedlots were owned by packers, whereas in 1952-53, the percentage dropped to 32 . This decline in packer ownership occurred, incidentally, during a period of decline in the price of cattle. Packer-owned cattle in eight other Western states accounted for a much lower percentage of cattle fed than in California. Data for Oregon and Washington were not available. No recent data on the importance of packerowned cattle are available, but if the level approximates that of a decade ago, the influence of slaughter plant location on cattle feeding is readily apparent. This fact may account, in part, for the difference between actual and estimated locations of feedlots in some regions. The equilibrium location of feeding would have to be considered jointly with the equilibrium location of slaughter plants.

\section{SUMMARY AND CONCLUSIONS}

Economic theory provides the framework for the determination of location of economic activity in a general equilibrium framework. The basic determinants of location include the following: regional endowment of natural resources, production functions that relate the combination of resources and factors in the production of intermediate and final products, the transfer functions for factors and products, and the demand functions for the final products. With given levels of factor availability, technology, and demand, these forces interact to provide a spatial equilibrium solution to the location of production and the associated flows of products and factors among regions consistent with equilibrium products prices in the various regions. The analysis of location of a particular industry undertaken in a partial equilibrium framework may ignore important interrelationships with other segments of the economy.

The location of feedlots in various regions of the country depends on a set of interdependent relationships espe- cially in the feed-livestock economy. In the aggregate, these relationships involve regional demand for various livestock products, production functions for livestock products and intermediate goods such as feeds and feeder cattle, regional availability of factors of production, and transfer cost functions for both products and intermediate products that tie regions together in a spatial equilibrium sense. An analysis of one segment of the livestock complex, such as cattle feeding, requires simplifying assumptions as to the other related segments of the feed-livestock complex.

Feedlot finishing of beef cattle basically involves the combination of intermediate products of feeder cattle, feed concentrates, and roughage with certain other factors such as labor, capital, and land, to produce a final productslaughter-weight cattle. In a sense, this also is an intermediate product since it must be processed and marketed before reaching the ultimate consumer. This model delineates an area of study concerned with the location of feedlots, 
with given regional demand of a particular year. Intermediate goods of feeder cattle, feed concentrates, and roughage may be shipped among regions. Meat is then shipped from producing regions to meet regional demand levels as specified in the demand function. As to the regional availability of resources such as land, it is assumed that feedlot requirements, as opposed to many types of agricultural products, are minor and that land is not a limiting factor in determining location. Similarly, labor and capital are not considered to be limiting factors. The limiting factors, thus become the intermediate products of feeder cattle, feed and roughage. The problem thus formulated is a spatial equilibrium model for the shipment of product and factors and is solved using linear programming techniques.

The basic specifications and assumptions employed in the model may be summarized as follows:

1. The model is static and based on conditions for the 1957-58 feeding year, with perfect competition assumed.

2. The location of the basic breeding herds (beef cows two years old and over) is taken as predetermined. The regional supply function for feeder calves thus is perfectly inelastic for the given year. Further, cattle are assumed to be of uniform quality by region and feeder cattle for shipment are of uniform weight of 650 pounds.

3. Production of feed concentrates and of roughage is assumed predetermined for each region, as is carryover and regional demand for feed (amount and combination) for livestock other than feeder cattle. Thus the supply of feeds available in each region for cattle feeding and for shipment is assumed completely inelastic for the given year. Feeds within the feed concentrate group are considered perfect substitutes in terms of net energy, and the same assumption is made for feeds within the roughage category.

4. Nonfeed costs of feedlot operations relate to a lot with a 5,000 head capacity. Feeding operations in any region may, by assumption, be expanded by adding more feedlots without increase in costs. Differences among regions in wage rates and in type of feedlot construction are taken into account.

5 . The production function relating feed inputs to weight gain is represented by nine feeding activities for each region. Coefficients vary between regions depending on the feeding efficiency determined for that region. Within a particular region, all feeders are assumed to face an identical production function.

6. The regional supply of beef that is not feedlot finished, which is referred to here as nonfed beef, is assumed predetermined at estimated 1958 levels; that the supply is independent of feeding operations; and that it is available, indistinguishable from fed beef, to meet the demand for beef both within the region and for shipment to other regions. An exception to this last mentioned condition is considered in model IV.

7. The quantity of beef consumed in each region is assumed to be a function of price, population, and per capita income. No account is taken of supplies or prices of other meats.

8. Each region is represented by a market point used for calculating transfer costs between regions, developed from an analysis of rail costs. Intraregional transfer costs based on truck costs, are allowed for by assuming standard average distances of feeding locations from the representative market points and from sources of supply of factors within the region. For product shipment, the feedlot operator is faced with the alternative of shipment within the region (market price less within-region transfer costs) or shipment to another region (market price less interegional transfer cost). Thus, within- or between-region transfer costs are deducted from market prices to obtain net prices facing feedlot operators 
in various regions. Factor transfer costs between regions are represented by rail costs minus within-region truck costs. Transfer costs within a region are deducted since feed and feeder production within the region would not correspond exactly to feedlot locations. The use of net transfer costs thus evaluates the relative ability of a surplus or deficit region to bid for feed or feeder supplies at the feedlot location.

9. The cost of slaughtering is assumed to equal the by-product value in all regions. Thus, the supply of slaughtering service is treated as perfectly elastic at the price represented by the byproduct value. Location of slaughter plants is assumed to approximate that for feedlots. Thus, the decision as to whether slaughter animals or meat are to be shipped depends on the relative rail rates, which turned out as calculated, always to favor meat shipment.

The equilibrium flows under the above model specifications are obtained by using a given set of regional product prices and associated quantities consumed consistent with the demand function. Imputed product prices are checked with the assumed prices and if these are not equal, a revised set of prices is used and the procedure repeated. At least three sets of prices were required to obtain the desired equilibrium conditions for each model.

In model I, feeding efficiency and nonfeed costs differed by region. The estimation of feeding efficiency was based on state agricultural experiment station data for recent years, including some 156 lots of cattle. Nonfeed costs associated with feedlot operations are specified for each of the production activities in each region. Regional differences in costs vary with type of feedlot facility (i.e., dirt lot, paved lot, or paved lot with shelter) and with labor costs based on reported data on farm wage rates. For a given region, nonfeed costs vary by production activity, depending on the length of time on feed. The time required for a given gain de- pends upon such factors as initial weight and the type of concentrateroughage ration fed-the higher the roughage proportion, the more time for a given gain. The time required for a given gain was estimated from the experiment station data also.

Results from model I do not provide any simple rules for determining the trend in location of feedlots in the United States. Rather, they emphasize the importance of recognizing the interrelationships among factors such as regional demand for meat, transfer cost functions, and the supply functions for factor and product. The fact that a region is in a deficit position for one or more factors does not necessarily preclude feeding in that region (e.g., region 3) nor does possession of an available supply of all factors insure that feeding will be located in that region (e.g., region 11). Regional differences in nonfeed costs and feeding efficiency specified in this model appear to be important reasons for the location pattern derived. If these specifications are correct, then the model has served its intended purpose of indicating the optimum location of cattle feeding that would result in the long run under perfect competition if conditions existing in 1958 were to persist. From the dual solution of the linear programming problem, however, we find that shifts in location between some regions may occur with little change in cost. The largest absolute difference between actual and estimated numbers fed occurred in region 10 (higher estimated numbers fed) and region 14 (lower estimated numbers fed). This difference accounted for about onehalf of the total "misallocated" output in the entire system. The total additional cost of a shift of location from region 10 to 14 appeared to rest on a cost of approximately four-tenths of a cent per pound for carcass beef. However, for other regions shifts in location from the model I optimum could be achieved only at considerable cost to the economy. 
Although the validity of a normative model should not be judged on its ability to indicate feeding locations as they actually existed in 1958, there is interest in the effect of changes in the specifications of the model on the location pattern. Refinements in the data available on feeding efficiency by region and on nonfeed costs, for example, would give us more confidence in the resulting pattern of location. Modifications in the specifications were therefore made in subsequent models. In model II, nonfeed costs were assumed to be equal in all regions. In model III, nonfeed costs and feeding efficiency were assumed to be equal in all regions. In model IV, nonfeed costs were assumed equal, and the proportion of beef consumed by region that was nonfed beef was forced to be equal in each region.

In model II nonfeed costs were set equal to those in California (regions 2 and 3 ). Since the Western region maintains self-sufficiency in beef production in all models, changes will be discussed for this region and for "all other regions." Nonfeed costs remained unchanged in region 3 but feeding increased due to the cost increase in other areas in the West. Feeding decreased in regions 7 and 9, those for which nonfeed costs were increased by the largest amount. Although the cost increase was greater in region 9, feeding decreased by a greater amount both in absolute and percentage terms in region 7 . This illustrates the importance of considering all relationships jointly rather than drawing conclusions from differences in cost of one factor alone. The number of head fed in the Western region decreased by 32,000 head, but the change in the feeding activities was such that the quantity of meat produced by decreased by only 2 million pounds. The shift was to a longer feeding period and results in lower feeder cattle requirements per 1,000 pounds of carcass beef produced.

In other regions, feeding was increased by regions 14 and 18 associated with lower nonfeed costs. The level of feeding in regions 13 and 16 remained unchanged in spite of lower nonfeed costs. In regions 10 and 12 , feeding was decreased associated with higher nonfeed costs. For the entire 20 regions, the location of feeding under model II corresponded somewhat more closely to actual location than under model I. Nonfeed costs appear to be an important variable in the model specification and warrant more careful study in any future refinement of the model.

In model III, nonfeed costs and feeding efficiency were assumed to be equal in all regions. A comparison of model II and model III provides a basis for isolating the effect of feeding efficiency on feedlot location. In the Western region, an increase in the feeding efficiency index in regions 6,8 , and 9 was associated with increased feeding in two regions and no change in the third. The feeding efficiency index was decreased in three regions $(3,4,5)$ and numbers of cattle fed also decreased. Feeding increased to the point where meat shipments were introduced to one region outside the West.

In other regions, the increase in feeding efficiency in two regions was associated with an increase in one region (11) and a decrease in the other region (12). This result is explained by a relatively greater increase in feeding.

Within the Western region, feeding was introduced or increased in two regions $(5,7)$ associated with the higher specification for fed beef, and decreased in region 3 associated with the lower specification for fed beef. In two regions $(1,2)$, feeding was not introduced in spite of more favorable conditions. In the remaining four regions in which the specification was unchanged, feeding increased in two $(6,8)$ and decreased in the other two $(4,9)$. As has been found previously, this result is due partly to the interrelated nature of factor shipment and product shipment patterns. In this case, it is partly due to the somewhat arbitrary allocation of shipments 
between fed and nonfed beef in the model II solution.

In other regions, feeding was introduced in region 11 associated with the higher specification for fed beef and decreased (regions 14 and 18) or remained unchanged (region 16) in three regions associated with the lower specification for fed beef. In three regions, no feeding was introduced in spite of the more favorable demand specification. In three regions in which the specification for fed beef remained essentially unchanged, feeding increased in two regions (12, 13) and decreased in region 10.

The adjustment in model IV is an attempt to specify a more realistic demand relation for beef; that is, one that differentiates between a good or choice grade animal marketed from the feedlot and an animal culled from the dairy herd. Other improvements in the demand function could be mentioned but are obvious to those familiar with demand analysis.

Other considerations that might provide improvements to a spatial equilibrium model of cattle feeding include the following: (1) differences in nonfeed costs associated with economies of scale for regions in which very large feedlots may be more feasible and where year-round feeding is possible; (2) a seasonal model that would allow consideration of the use of seasonal range for stocker animals and the shipment of feeder animals from breeding areas at lighter weights than that assumed in the model; (3) inclusion of other livestock products in the demand and supply functions to give a more general equilibrium solution; (4) improved data on regional beef demand and feeding efficiency, nonfeed costs, and feed supplies would of course be desirable; and (5) consideration of the interrelated nature of adjustments of location of feedlots and slaughter plants.
The principal conclusions to be drawn from this analysis relate to the usefulness of the general approach and to the applicability of the findings in indicating possible direction of change in the location of cattle feeding. The analyses point out the importance of consideration of the interrelated nature of both factor and product shipment in a spatial equilibrium analysis of cattle feeding location. In general, the approach would be strengthened considerably from a theoretical viewpoint by consideration of alternative uses for feed by various types of livestock rather than the partial equilibrium approach used. Some useful results were obtained by tracing the effect of alternative assumptions as to feeding efficiency and nonfeed costs that might not be possible in a more complex model.

The location of feeding in the models differed substantially from the actual 1958 level. The exact difference in cost between actual and estimated locations cannot be precisely determined since data are not available for shipments of feeder cattle, feed concentrates, and roughage, or for actual consumption levels of beef by region. It has been shown that small changes in the specification of nonfeed costs or feeding efficiency by region result in sharp shifts in the location of feeding. Further refinement of the basic data and inclusion of the production functions for alternative livestock products would appear to be justified for studies designed for other purposes, such as to determine the effect on location of alternative government programs for wheat and feed grains. Computational problems could be reduced by considering fewer regions and fewer production activities for each region. However, the problems encountered in this analysis should give caution to the research worker in formulating more complex models. 


\section{APPENDIX A}

\section{DEVELOPMENT OF FEED DATA}

\section{CONCENTRATES}

Total concentrate feed available for feeding to livestock by region is shown in appendix table A-1. Feed available is defined as beginning stocks plus current crop plus imports from outside the United States minus ending stocks minus seed use minus industrial use minus exports outside the United States. The appearance of negative quantities for some feed merely indicates inshipments from other regions being carried out as stocks.

The net energy value of total feeds, use of feed by livestock other than fed cattle, and net feed available for cattle feeding are shown in appendix table
A-2. The following factors were used to place the feeds on a net energy basis (Morrison, 1956) :

FEED

Barley (Pacific Coast)

THERMS OF

NET ENERGY

PER TON

Barley (other)

1,428

1,410

1,556

$\begin{array}{ll}\text { Oats } & 1,602\end{array}$

Corn $\quad 1,602$

Wheat and rye $\quad 1,506$

By-product feed excl. molasses and alfalfa meal

1,420

Molasses

1,122

Alfalfa meal

904

Formula feeds

APPENDIX TABLE A-1

Concentrate Feed Avallable Year Beginning October 1, 1957*

(Thousand tons)

\begin{tabular}{|c|c|c|c|c|c|c|c|c|c|}
\hline Region & Barley & $\underset{\text { grain }}{\text { Sorghum }}$ & Oats & Corn & $\begin{array}{l}\text { Wheat } \\
\text { and } \\
\text { rye }\end{array}$ & $\begin{array}{c}\text { By- } \\
\text { products } \\
\text { feeds } \\
\text { other } \\
\text { than } \\
\text { molasses } \\
\text { and } \\
\text { alfalfa } \\
\text { meal }\end{array}$ & Molasses & $\begin{array}{c}\text { Alfalfa } \\
\text { meal }\end{array}$ & $\begin{array}{l}\text { Net } \\
\text { effect of } \\
\text { foreign } \\
\text { trade in } \\
\text { formula } \\
\text { feed }\end{array}$ \\
\hline $1 \ldots \ldots \ldots \ldots \ldots$ & 114 & -111 & 208 & 43 & 86 & 604 & 31 & 18 & -76 \\
\hline $2 \ldots \ldots \ldots \ldots \ldots$ & 1,034 & -233 & 15 & 158 & 13 & 831 & 70 & 140 & 5 \\
\hline $\mathbf{3} \ldots \ldots \ldots \ldots \ldots$ & 182 & -13 & 7 & -30 & 1 & 610 & 32 & 41 & 34 \\
\hline $\mathbf{4} \ldots \ldots \ldots \ldots \ldots$ & 17 & -27 & 4 & 1 & 8 & 2 & $-\S$ & 7 & - \\
\hline $\boldsymbol{5} \ldots \ldots \ldots \ldots \ldots$ & 593 & -31 & 166 & - & 89 & 313 & 54 & 12 & - \\
\hline$\ldots \ldots \ldots \ldots \ldots$ & 249 & 87 & 9 & 32 & 4 & 149 & - & 8 & - \\
\hline $7 \ldots \ldots \ldots \ldots \ldots$ & 926 & - & 187 & 14 & 80 & 129 & 34 & 14 & - \\
\hline $8 \ldots \ldots \ldots \ldots \ldots$ & 397 & 413 & 78 & 322 & 38 & 222 & 56 & 119 & - \\
\hline $\mathbf{9} \ldots \ldots \ldots \ldots \ldots$ & 22 & 161 & 6 & 24 & 7 & 20 & - & 10 & - \\
\hline $10 \ldots \ldots \ldots \ldots \ldots \ldots$ & 1,980 & 159 & 2,339 & 3,326 & 63 & 179 & 13 & 16 & - \\
\hline $11 \ldots \ldots \ldots \ldots \ldots$ & 531 & 3,731 & 1,088 & 6,386 & 144 & 1,252 & 24 & 551 & - \\
\hline $12 \ldots \ldots \ldots \ldots \ldots$ & 48 & 2,441 & 640 & 349 & 69 & 1,974 & 2 & 34 & -104 \\
\hline $13 \ldots \ldots \ldots \ldots \ldots \ldots$ & -656 & - & 4,500 & 11,038 & 50 & 2,140 & 22 & 28 & 35 \\
\hline $14 \ldots \ldots \ldots \ldots \ldots \ldots$ & 61 & 647 & 5,086 & 30,613 & 150 & 6,616 & 102 & 84 & - \\
\hline $15 \ldots \ldots \ldots \ldots \ldots \ldots$ & -138 & 61 & 145 & 786 & 45 & 1,659 & 384 & 10 & -287 \\
\hline$\cdots \ldots \ldots \ldots \ldots \ldots \ldots$ & 168 & 36 & 1,582 & 11,961 & 299 & 2,802 & 40 & 115 & 2 \\
\hline $17 \ldots \ldots \ldots \ldots \ldots \ldots$ & 116 & 93 & 81 & 2,534 & 66 & 1,221 & - & 10 & - \\
\hline $18 \ldots \ldots \ldots \ldots \ldots \ldots$ & -249 & -84 & 975 & 725 & 235 & 1,967 & 2 & 30 & -34 \\
\hline $19 \ldots \ldots \ldots \ldots \ldots$ & -57 & 105 & 454 & 3,546 & 153 & 906 & - & - & -5 \\
\hline $20 \ldots \ldots \ldots \ldots \ldots \ldots$ & 1 & -1 & 4 & 213 & - & 147 & 141 & - & -3 \\
\hline United States. . . . . . & 5,339 & 7,434 & 17,574 & 72,041 & 1,600 & 23,743 & 1,007 & 1,247 & -433 \\
\hline
\end{tabular}

* Feed available $=$ beginning stock + crop + imports - ending stock - seed - industrial use - exports. t Corn as grain, shelled corn basis.

Wheat and rye fed.

Dashes indicate less than 500 tons.

Source: King, G. A., 1961. 
APPENDIX TABLE A-2

Roughage Feed Production by Region, October, 1957-September, 1958

(Thousand tons)

\begin{tabular}{|c|c|c|c|c|c|c|c|c|c|}
\hline Region & $\begin{array}{l}\text { Corn } \\
\text { silage }\end{array}$ & $\begin{array}{c}\text { Sorghum } \\
\text { silage }\end{array}$ & $\begin{array}{l}\text { Wet } \\
\text { beet } \\
\text { pulp }\end{array}$ & $\begin{array}{l}\text { Grass } \\
\text { silage }\end{array}$ & $\begin{array}{c}\text { Alfalfa } \\
\text { and } \\
\text { alfalfa } \\
\text { mixtures }\end{array}$ & $\begin{array}{l}\text { Clover } \\
\text { and } \\
\text { timothy }\end{array}$ & $\underset{\text { hay }}{\text { Grain }}$ & $\begin{array}{l}\text { Wild } \\
\text { hay }\end{array}$ & $\begin{array}{c}\text { Lespe- } \\
\text { deza }\end{array}$ \\
\hline 1. & 405 & - $^{*}$ & 136 & 750 & 2,020 & 752 & 347 & 401 & - \\
\hline 2 & 830 & 89 & 310 & 63 & 4,076 & - & 721 & 142 & - \\
\hline 3. & 220 & 11 & 140 & 22 & 1,364 & - & 134 & 22 & - \\
\hline $4 \ldots \ldots$ & 42 & - & - & 4 & 374 & 53 & 11 & 220 & - \\
\hline $\mathbf{5} \ldots \ldots \ldots \ldots \ldots$ & 1,190 & - & 232 & 113 & 4,097 & 294 & 65 & 246 & - \\
\hline 6. & 75 & 630 & - & 15 & 726 & - & 92 & - & - \\
\hline$\ldots$ & 660 & - & 151 & 17 & 2,761 & 490 & 300 & 923 & - \\
\hline 8 & 2,619 & 562 & 249 & 29 & 1,994 & 320 & 140 & 322 & - \\
\hline 9. & 156 & 140 & - & 5 & 515 & 11 & 24 & 18 & - \\
\hline 10 . & 4,006 & 387 & 56 & 3 & 6,411 & - & 235 & 4,029 & - \\
\hline 11. & 2,682 & 7,203 & 107 & 118 & 7,989 & 71 & 317 & 3,390 & 56 \\
\hline $12 \ldots$ & 280 & 1,814 & - & 30 & 1,168 & - & 883 & 626 & 62 \\
\hline $13 \ldots \ldots$ & 16,466 & - & 95 & 1,781 & 12,013 & 3,370 & 81 & 602 & - \\
\hline $14 \ldots \ldots$ & 6,341 & 2,823 & - & 834 & 10,934 & 3,498 & 699 & 209 & 1,475 \\
\hline $15 \ldots \ldots \ldots \ldots \ldots \ldots$ & 316 & 688 & 一 & 143 & 239 & 349 & 438 & 196 & 902 \\
\hline 16 . & 5,013 & 144 & 124 & 2,187 & 6,033 & 3,471 & - & - & 98 \\
\hline $17 \ldots \ldots$ & 747 & 352 & - & 327 & 1,299 & 1,326 & 408 & - & 1,465 \\
\hline 18 & 10,292 & - & - & 3,116 & 4,216 & 7,082 & 147 & - & 56 \\
\hline $19 \ldots$ & 1,608 & 314 & - & 357 & 815 & 626 & 649 & - & 725 \\
\hline $20 \ldots \ldots$ & 119 & - & - & 17 & - & - & - & - & - \\
\hline United States.... & 54,067 & 15,157 & 1,600 & 9,931 & 69,044 & 21,713 & 5,691 & 11,346 & 4,839 \\
\hline
\end{tabular}

* Dashes indicate amount too small to be significant.

APPENDIX TABLE A-2-Continued

\begin{tabular}{|c|c|c|c|c|c|c|c|}
\hline Region & Cowpea & Soybean & Peanut & $\begin{array}{l}\text { Other } \\
\text { hay }\end{array}$ & $\begin{array}{c}\text { Sorghum } \\
\text { forage }\end{array}$ & $\begin{array}{l}\text { Cotton- } \\
\text { seed } \\
\text { hulls }\end{array}$ & $\begin{array}{l}\text { Net effect } \\
\text { of stock } \\
\text { change }\end{array}$ \\
\hline $1 \ldots \ldots \ldots \ldots \ldots \ldots$ & $\dagger$ & & & 257 & & & -274 \\
\hline $2 \ldots \ldots \ldots \ldots \ldots \ldots \ldots \ldots$ & & & & 328 & 6 & 104 & -54 \\
\hline $3 \ldots \ldots \ldots \ldots \ldots \ldots \ldots$ & & & & 50 & 1 & 21 & -15 \\
\hline$\ldots \ldots \ldots \ldots$ & & & & 8 & & & -57 \\
\hline $5 \ldots \ldots \ldots$ & & & & 37 & & & -322 \\
\hline $6 \ldots$ & & & & 25 & 12 & 60 & -85 \\
\hline $7 \ldots \ldots \ldots \ldots$ & & & & 201 & 9 & & -735 \\
\hline $8 \ldots$ & & & & 110 & 762 & & -474 \\
\hline $9 \ldots \ldots \ldots \ldots$ & & & 1 & 25 & 113 & 7 & -71 \\
\hline $10 \ldots \ldots \ldots \ldots$ & & & & 584 & 251 & & $-2,358$ \\
\hline 11. & & 5 & & 428 & 2,425 & & $-2,772$ \\
\hline $12 \ldots \ldots \ldots$ & 8 & 7 & 103 & 1,197 & 3,154 & 333 & -753 \\
\hline $13 \ldots \ldots$ & & 6 & & 260 & & & -489 \\
\hline $14 \ldots \ldots \ldots$ & 2 & 68 & & 352 & 393 & 6 & $-1,447$ \\
\hline $15 \ldots \ldots \ldots$ & 22 & 167 & 68 & 1,248 & 229 & 185 & -16 \\
\hline 16. & & 49 & & 181 & & 3 & 317 \\
\hline $17 \ldots$ & 10 & 168 & 2 & 392 & 98 & 60 & 319 \\
\hline $18 \ldots$ & & 36 & & 867 & & & 308 \\
\hline $19 \ldots \ldots \ldots$ & 115 & 122 & 240 & 399 & 55 & 82 & 277 \\
\hline $20 \ldots \ldots \ldots$ & & & 26 & 170 & & 3 & 15 \\
\hline United States. . & 157 & 628 & 440 & 7,119 & 7,508 & 864 & $-8,686$ \\
\hline
\end{tabular}

$\dagger$ Blanks indicate amount too small to be significant. 
APPENDIX TABLE A-3

Hay Equivalent of Roughage Feeding Rates by Region and Class of Livestock 1957-1958 SEASON

\begin{tabular}{|c|c|c|c|c|c|c|}
\hline Region & Dairy cows & Other dairy & Beef cows & $\begin{array}{l}\text { Other beef } \\
\text { except cattle } \\
\text { on feed }\end{array}$ & $\begin{array}{l}\text { Horses } \\
\text { and } \\
\text { mules }\end{array}$ & $\begin{array}{l}\text { Sheep } \\
\text { and } \\
\text { lambs }\end{array}$ \\
\hline $1 \ldots \ldots \ldots \ldots$ & 3.4 & 1.22 & 1.66 & .91 & 1.82 & .1 \\
\hline $\mathbf{2} \ldots \ldots \ldots \ldots$ & 3.7 & 1.33 & 1.58 & 1.18 & 3.38 & .1 \\
\hline $3 \ldots$ & 3.7 & 1.33 & 1.58 & 1.18 & 3.38 & .1 \\
\hline $4 \ldots \ldots$ & 3.7 & 1.33 & .85 & .55 & 1.97 & .1 \\
\hline $\boldsymbol{5} \ldots \ldots \ldots$ & 5.0 & 1.79 & 2.21 & 1.22 & 1.44 & .1 \\
\hline 6. & 4.0 & 1.44 & .31 & .35 & 1.23 & .1 \\
\hline $7 \ldots$ & 3.15 & 1.13 & 1.23 & .91 & 1.24 & .1 \\
\hline 8 & 3.9 & 1.40 & 1.21 & .93 & 1.09 & .1 \\
\hline $9 \ldots$ & 3.1 & 1.12 & .23 & .20 & .47 & .1 \\
\hline $10 \ldots \ldots \ldots \ldots$ & 4.15 & 1.50 & 1.81 & 1.12 & 1.45 & .1 \\
\hline $11 \ldots$ & 3.1 & 1.12 & 1.52 & .82 & 1.24 & .1 \\
\hline I2... & 2.05 & .74 & .26 & .14 & .68 & .1 \\
\hline $13 \ldots$ & 4.0 & 1.44 & 2.56 & 1.56 & 1.38 & .1 \\
\hline $14 \ldots$ & 3.2 & 1.15 & 1.25 & .84 & 1.10 & .1 \\
\hline $15 \ldots \ldots \ldots \ldots$ & 1.4 & .51 & .18 & .14 & 1.07 & .1 \\
\hline 16. & 3.5 & 1.25 & 1.50 & .99 & 1.52 & .1 \\
\hline 17. & 2.2 & .79 & 1.81 & 1.10 & 1.21 & .1 \\
\hline 18. & 3.55 & 1.28 & 2.19 & 1.38 & 3.17 & .1 \\
\hline 19. & 2.3 & .83 & 1.20 & .68 & 1.41 & .1 \\
\hline $20 \ldots \ldots \ldots$ & 1.1 & .39 & 0 & 0 & .95 & 1 \\
\hline
\end{tabular}

The feedstuffs used in manufacturing formula feeds are included in the feeds availability data and therefore only a correction for the effect of foreign trade need be included. The model treats interregional shipments of formula feeds as a part of the concentrate feed group.

\section{ROUGHAGES}

Roughage production by crop and region for the 1957-58 season are shown in appendix table A-2. The basic data source is reported by the Agricultural Marketing Service (1958) in Crop Production. The total production of wet beet pulp is assumed to be the same as reported by Jennings (1958) for 1956. The regional distribution is estimated based on the distribution of sugar beet processing. The utilization of grass silage is based on the use of grass silage in dairy rations reported by the Agricultural Marketing Service (1959B) in Milk Production. It is assumed that all grass silage is used in dairy herds.

On-farm stocks of hay are reported as of May 1. In the current study May 1, 1957 stocks are treated as beginning stocks. For purposes of computing the effect of stocks on total supply available all stocks are treated as if they were carried as alfalfa hay. Since alfalfa meal is treated as a concentrate feed the total net energy equivalent of alfalfa meal production is subtracted from the roughage supply. Hay used in meal production is included in the alfalfa production data.

Total net energy equivalent of roughage feeds available, fed to livestock other than feeder cattle, and roughage available for cattle feeding are shown in table 4. Estimates of roughage used by other livestock are on a hay equivalent basis. Three tons of silage are equivalent to one ton of hay. Dairy cow feeding rates were based on rations reported in Milk Production. Feeding rates for other dairy cattle were estimated based on a requirement of one ton of hay per head per year and regional differences set in accord with the re- 
ported milk cow rations. Roughage feeding rates for the remaining classes of livestock were based on estimates in R. D. Jennings (1954) for the 1949 feeding year. The feeding rates used in terms of hay equivalent of all roughage are shown in appendix table A-3. Feeding rates are expressed as tons per head on farms January 1. The resulting estimates of roughage use were converted to a net energy basis using the average net energy content of the hay equivalent of all roughages (taking 808.2 therms per ton).

The following values in the text table in the adjoining column were used for the conversion of various roughages to a net energy basis:
FEED

Alfalfa and alfalfa mixtures (hay)

Clover and timothy hay

Grain hay

Wild hay

Lespedeza hay

Cowpea hay

Soybean hay

Peanut hay

Other hay

Sorghum forage

Cottonseed hulls

Corn silage

Sorghum silage

Wet beet pulp

Grass silage
THERMS OF NET ENERGY PER TON

702

586

326

244

180

266 


\section{APPENDIX B}

Sources of Data Used in Estimation of the Beef Production Function

Various authors, Feeding and Breeding Tests, Oklahoma Agr. Exp. Sta. Misc. Publ. 51 (Stillwater, 1958).

Various authors, Beef Cattle Feeding Investigations 1957-1958, Kansas Agr. Exp. Sta. Circ. 359 (Manhattan, 1958), pp. 1-22.

W. B. Anthony and others, Fattening Rations for Finishing Steers After Summer Grazing, Alabama Agr. Exp. Sta. Progr. Rept. Ser. 59 (Auburn, 1955), pp. 1-8.

M. C. BELL and others, Wood Molasses for Lambs and Steers, Tennessee Agr. Exp. Sta. Bul. 253 (Knoxville, 1956), pp. 1-13.

J. R. Brethour et al., 1958-1959 Beef Cattle Feeding Investigation, Kansas Agr. Exp. Sta. Circ. 363 (Manhattan, 1959).

M. T. Clegg, R. Albaugh, and H. H. Cole, The Use of Stilbestrol in Fattening Cattle, California Agr. Exp. Sta. Circ. 441 (Berkeley, 1954).

C. C. Culbertson, W. Burroughs, J. Kastelic, and W. E. Hammond, Results of Cattle Feeding Experiments, Iowa Agr. Exp. Sta. AH 693 (Ames, 1955).

R. J. Douglas and others, Feeding Yearling Steers, North Dakota Agr. Exp. Sta. Bimonthly Bul. 20 (Fargo, 1957), pp. 4-9.

T. W. Dowe and others, Full Feeding vs. Limited Feeding for Beef Production in Dry Lot and on Pasture, Nebraska Agr. Exp. Sta. Bul. 440 (Lincoln, 1957), pp. 1-23.

T. W. Dowe and others, "Effects of Adequate and Excessive Calcium When Fed with Adequate Phosphorus in Growing Rations for Beef Calves," J. Animal Science, Vol. 16, 1957, pp. 811-820.

A. L. Harvey and O. E. Kolari, "Adding Stilbestrol and an Antibiotic to Cattle Feeding Rations," Farm and Home Science, 15:(6) Minnesota Agr. Exp. Sta. (St. Paul, 1958).

N. R. ItTNeR, T. E. Bond, and C. F. KELLY, Methods of Increasing Beef Production in Hot Climates, California Agr. Exp. Sta. Bul. 761 (Berkeley, 1958).

R. F. Johnson, E. F. Rinemart, and C. W. Hickman, Potato Silage for Beef Steers, Idaho Agr. Exp. Sta. Bul. 293 (Moscow, 1953).

T. B. KeITH and others, Two Ratios of Concentrate to Roughage, Four Protein Levels, Two Corn Silage Levels, and Two Oil Levels for Steers, Idaho Agr. Exp. Sta. Res. Bul. 40 (Moscow, 1958), pp. 1-13.

E. W. Klosterman and L. E. KunkLe, Utilization of Meadow Crops by Fattening Cattle, Ohio Agr. Exp. Sta. Res. Bul. 821 (Columbus, 1958), pp. 1-16.

E. W. Klosterman and others, Value of Wheat Protein Hydrolysate as a Protein Supplement for Fattening Cattle, Ohio Agr. Exp. Sta. Res. Circ. 36 (Columbus, 1956), pp. 1-8.

L. H. LANGFord and R. J. Douglas, Spayed Heifers vs. Steers and Open Heifers for Feeding, North Dakota Agr. Exp. Sta. Bimonthly Bul. 19 (Fargo, 1956), pp. 53-57.

L. H. LANGFORD and others, Fattening Steers, Open Heifers and Spayed Heifers on High Roughage Rations, North Dakota Agr. Exp. Sta. Bimonthly Bul. 18 (Fargo, 1955), pp. 46-48.

W. J. Loeffel, Grain Sorghums as Feeds for Beef Cattle and Hogs, Nebraska Agr. Exp. Sta. Bul. 439 (Lincoln, 1957), pp. 1-35.

W. C. MсCоRміск and others, Comparative Value of Coastal Bermuda Grass Silage and Hay for Fattening Steers, Georgia Agr. Exp. Sta. Circ. 10 (Athens, 1957), 1015 p.

J. I. MILlER and others, Feeding Value of Mixed Hays, Grass Silage, and Corn Silage for Steer Calves and Beef Cows, Cornell Agr. Exp. Sta. Bul. 923 (Ithaca, 1957), pp. 1-32.

E. G. Morrison, Various Feed Grains Compared for Fattening Steers, Mississippi Agr. Exp. Sta. Farm Res. 19 (State College, 1956).

O. F. PAHnish and others, Effects of Roughage Levels on Fattening Cattle in Arizona, Arizona Agr. Exp. Sta. Bul. 272 (Tucson, 1956), pp. 1-9.

B. L. Southwell and others, Value of Wood Molasses for Fattening Steers, Georgia Agr. Exp. Sta. Techn. Bul. 8 (Athens, 1956), pp. 1-10.

H. T. Strong, M. T. Clegg, and J. H. Meyer, Enzymes as a Feed Additive for Finishing Beef Cattle, Dept. Animal Husbandry, Univ. of California (Davis, 1959).

H. Thurber, M. T. Clegg, H. T. Strong, Feed Cattle Feeding Trials with Hormones in Imperial County, California Agr. Ext. Serv. (El Centro, 1957).

W. C. Weir, J. H. Meyer, W. N. Garrett et al., "Pelleted Rations Compared to Similar Rations Fed Chopped or Ground for Steers and Lambs," J. Animal Science, 18(2), May, 1959.

R. F. WheEler, S. G. Woods, R. L. EdWards, and C. W. ACKerman, Diethyistilbestral in Fattening Rations for Dry-Lot Steers, South Carolina Agr. Exp. Sta. Bul. 483 (Clemson, 1960).

J. C. Williams and others, Fattening Light Steers and Heifers in the Gulf Coast Area, Texas Agr. Exp. Sta. Progr. Rep. 1982 (College Station, 1957), pp. 1-3.

J. C. Williams and others, Fattening Steer and Heifer Calves in the Gulf Coast Area, Texas Agr. Exp. Sta. Progr. Rep. 2106 (College Station, 1959), pp. 1-3. 


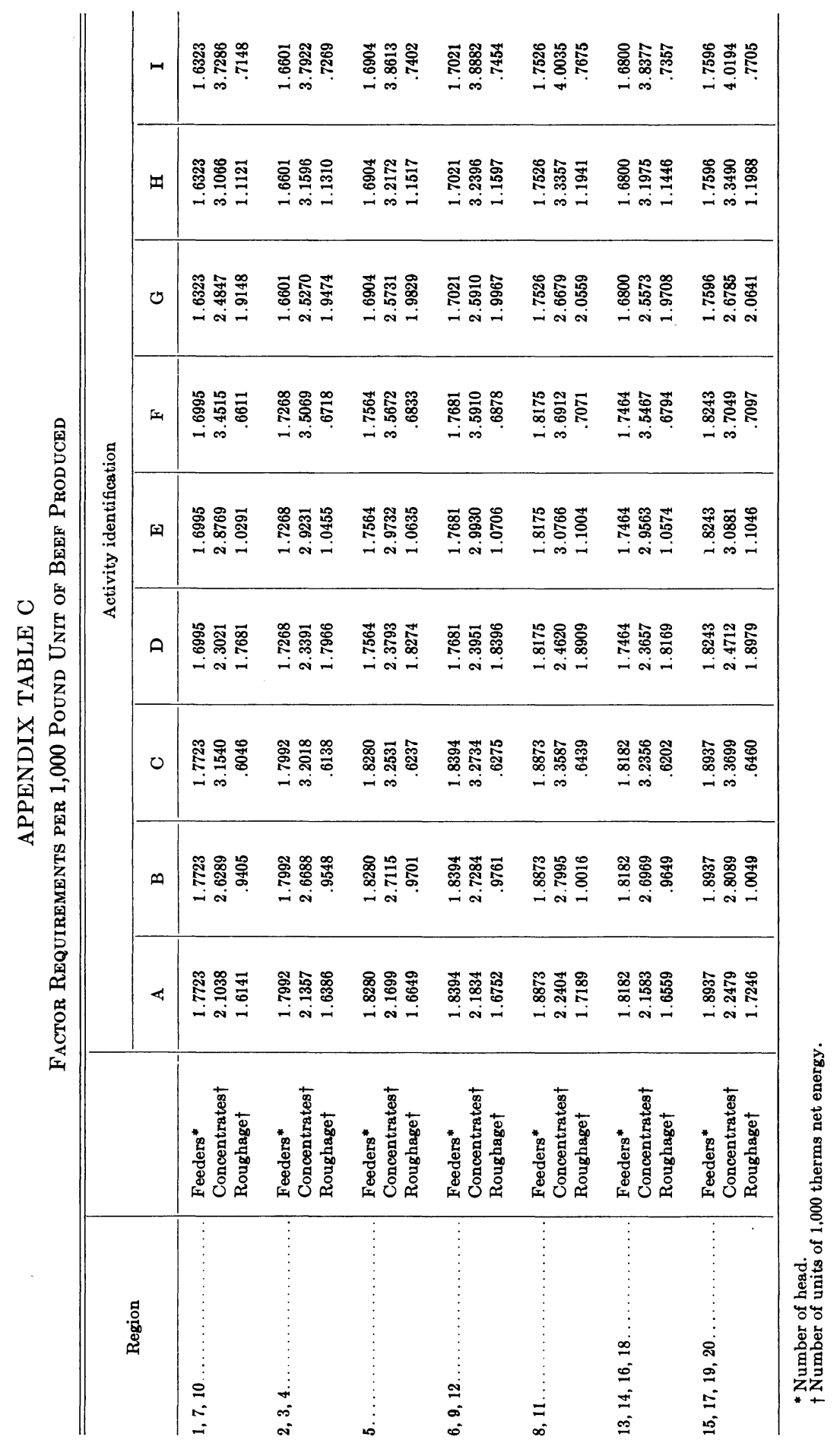


APPENDIX TABLE D

Non-Feed Cost per 1,000 Pound Unit of Beef*

\begin{tabular}{|c|c|c|c|c|c|c|c|c|c|}
\hline \multirow{2}{*}{ Region } & \multicolumn{9}{|c|}{ Activity identification } \\
\hline & $\mathbf{A}$ & B & $\mathrm{C}$ & D & $\mathbf{E}$ & $\mathbf{F}$ & $\mathrm{G}$ & $\mathbf{H}$ & I \\
\hline $1 \ldots \ldots \ldots \ldots$ & $\$ 23.95$ & $\$ 23.16$ & $\$ 23.35$ & $\$ 24.29$ & $\$ 23.34$ & $\$ 23.53$ & $\$ 24.51$ & $\$ 23.51$ & $\$ 23.79$ \\
\hline $2 \ldots$ & 23.89 & 23.11 & 23.30 & 24.24 & 23.30 & 23.49 & 24.47 & 23.48 & 23.75 \\
\hline $3 \ldots \ldots \ldots \ldots$ & 23.89 & 23.11 & 23.30 & 24.24 & 23.30 & 23.49 & 24.47 & 23.48 & 23.75 \\
\hline $\mathbf{5} \ldots \ldots \ldots \ldots$ & 22.56 & 21.86 & 22.03 & 22.86 & 22.01 & 22.18 & 23.06 & 22.17 & 22.41 \\
\hline$\ldots$ & 21.84 & 21.17 & 21.34 & 22.11 & 21.31 & 21.47 & 22.28 & 21.44 & 21.67 \\
\hline$\ldots \ldots$ & 21.15 & 20.50 & 20.66 & 21.36 & 20.59 & 20.74 & 21.48 & 20.67 & 20.89 \\
\hline 8. & 22.19 & 21.52 & 21.68 & 22.50 & 21.69 & 21.85 & 22.70 & 21.85 & 22.08 \\
\hline 9. & 20.01 & 19.44 & 19.58 & 20.18 & 19.51 & 19.64 & 20.29 & 19.57 & 19.77 \\
\hline $13 \ldots \ldots \ldots$ & 26.70 & 26.05 & 26.21 & 26.74 & 25.96 & 26.11 & 26.70 & 25.87 & 26.10 \\
\hline $14 \ldots \ldots \ldots \ldots$ & 26.38 & 25.75 & 25.90 & 26.41 & 25.64 & 25.80 & 26.35 & 25.55 & 25.77 \\
\hline $15 \ldots \ldots \ldots \ldots$ & 21.47 & 20.95 & 21.08 & 21.55 & 20.93 & 21.05 & 21.57 & 20.91 & 21.09 \\
\hline 16. & 26.17 & 25.54 & 25.70 & 26.18 & 25.43 & 25.58 & 26.12 & 25.33 & 25.55 \\
\hline 17. & 21.80 & 21.27 & 21.40 & 21.90 & 21.26 & 21.39 & 21.93 & 21.25 & 21.43 \\
\hline 18. & 27.44 & 26.75 & 26.93 & 27.52 & 26.69 & 26.86 & 27.51 & 26.63 & 26.87 \\
\hline 19. & 21.58 & 21.06 & 21.19 & 21.67 & 21.04 & 21.16 & 21.69 & 21.02 & 21.20 \\
\hline $20 \ldots \ldots \ldots$ & 22.69 & 22.11 & 22.25 & 22.83 & 22.13 & 22.27 & 22.90 & 22.16 & 22.36 \\
\hline
\end{tabular}

* Nonfeed cost per beef units equals nonfeed cost per head (see table 7) multiplied by the number of feeders per beef unit (see appendix table C). 


\section{LITERATURE CITED}

AdAMs, R. L.

1954. Farm management livestock manual. rev. ed., Univ. of California Press, Berkeley.

BaUmol, William J.

1952. Spatial equilibrium with supply points separated from markets and with supplies predetermined. Rept. under contract with the U. S. Dept. of Agr., Bur. of Agr. Econ. (Hectographed.)

BECKMANN, MARTIN

1952. A continuous model of transportation. Econometrica 20 (4) :643-60.

Dennis, C. C., and L. L. SAMmeT

1961. Interregional competition in the frozen strawberry industry. Hilgardia 31 (15):499-611.

Dorfman, Robert, Paul A. Samuelson, and Robert M. Solow

1958. Linear programming and economic analysis. McGraw-Hill Book Co., Inc., New York.

DUNN, EDGaR

1954. The location of agricultural production. Univ. of Florida Press, Gainesville.

Foote, R. J., and K. A. Fox

1952. Seasonal variation: methods of measurement and tests of significance. U. S. Dept. of Agr., Agr. Handbook 48.

Fox, K. A., and R. C. TAEuber

1955. Spatial equilibrium models of the livestock-feed economy. Amer. Econ. Rev. 45 (4):584608.

Henderson, James M.

1958. The efficiency of the coal industry. Harvard Univ. Press, Cambridge.

Henry, W. R., and C. E. Bishop

1957. North Carolina broilers in interregional competition. North Carolina State Coll. A.E. Inf. Ser. 56.

Hoover, Edgar M., JR.

1937. Location theory and the shoe and leather industries. Harvard Univ. Press, Cambridge.

Hopkin, J. A.

1957. Cattle feeding in California. Econ. Dept., Bank of America N.T. \& S.A., San Francisco.

ISARD, WALTER

1956. Location and space-economy. The Technology Press of Massachusetts Inst. of Technology, Cambridge, and John Wiley \& Sons, Inc., New York.

JENNINGS, R. D.

1954. Feed consumed by livestock, supply and disposition of feeds, 1949-50, by states. U. S. Dept. of Agr. Stat. Bul. 145, Washington, D.C.

1958. The consumption of feed by livestock, 1909-56. U. S. Dept of Agr. Prod. Res. Rept. 21.

JUDGE, G. G., and T. D. WALLACE

1959. Spatial price equilibrium analyses of the livestock economy, I. Methodological development and annual spatial analyses of the beef marketing sector. Oklahoma Agr. Exp. Sta. Tech. Bul. T-78.

KING, GoRdon A.

1961. Regional supply and distribution of feed, 1957-58. Berkeley, Giannini Found. Agr. Econ. Res. Rept. 248.

1962. Economies of scale in large commercial feedlots. Berkeley, Giannini Found. Agr. Econ. Res. Rept. 251.

Koopmans, TJallings, and Martin BeckmanN

1957. Assignment problems and the location of economic activities. Econometrica 25 (1):5376.

Lanahan, Thomas J., JR.

1957. "A Review of 1955 Survey Data on Household Meat Consumption." National Food Situation, NFS-80 pp. 51-68, Agr. Marketing Serv., Wash., D.C.

LEFEBER, LOUIS

1958. Allocation in space: production, transport and industrial location. North-Holland Publishing Company, Amsterdam.

Lösch, AUGUST

1944. Die räumliche Ordnung der Wirtschaft, G. Fischer, Jena; Translated from the second revised edition by W. H. Woglom with the assistance of W. F. Stolper, The Economics of Location, Yale Univ. Press, New Haven, 1954.

McGlothlin, RoBerT S.

1957. Hay and feed grains in the west. Arizona Agr. Exp.. Sta. Bul. 289.

MORRISON, F. B.

1956. Feeds and feeding, a handbook for the student and stockman, 22nd ed., The Morrison Publishing Co., Ithaca. 
National Railway Publication Company

1960. The official guide of the railways and steam navigation lines of the United States.

Public Utilities Commission of the State of California

1959. Minimum rate tariff No. 2 and Minimum rate tariff No. 3A. San Francisco.

RAND MCNALly CoMpaNy

1960. Commercial atlas and marketing guide, 1960, 91st ed., Chicago.

Samuelson, Paul A.

1949. International factor-price equilization once again. The Econ. J. 59 (234).181-97.

1952. Spatial price equilibrium and linear programming. Amer. Econ. Rev. 42 (3) :283-303.

Schrader, L. F., and G. A. KING

1962. Regional location of beef cattle feeding. J. of Farm Econ. 44 (1) : 64-81.

SCOTT, Frank S., JR.

1955. Marketing aspects of western cattle finishing operations. Nevada Agr. Exp. Sta. Bul. 190.

Snodgrass, M. M., and C. E. French

1958. Linear programming approach to the study of interregional competition in dairying. Indiana Agr. Exp. Sta. Bul. 637.

SOUTHERN PACIFIC COMPANy

1929. Local and joint distance table no. 420-D. (loose leaf) San Francisco.

THUNEN, JOHANN HEINRICH vON

1930 ed. Der isolierte Staat in Beziehung auf Landwirtschaft und Nationalökonomie, dritte Auflage. Gustav Fischer, Jena.

United States Agricultural Marketing Service

1958. Crop production, 1958 annual summary. Cr. Pr. 2-1-58 Wash., D.C.

1959a. Farm labor. La 1 (1-59) Wash., D.C.

1959b. Milk production. Da 1-1 (6-59). Wash., D.C.

1959c. Livestock and Meat Statistics. Suppl. for 1958 to Stat. Bul. 230. Wash., D.C.

1960. The marketing and transportation situation. MTS-136. Wash., D.C.

United States Bureau of the Census

1959a. Current population report, series P-25, 210. Wash., D.C.

1959 b. U. S. Imports of merchandise for consumption. FT 110. Wash., D.C.

UNITED States Department OF AGRICUlTURE

1958. Livestock and meat statistics, 1957. Stat. Bul. 230. Wash., D.C.

1961. Cattle and calves on feed. Stat. Bul. 277. Wash., D.C.

United States Department OF Commerce

1960. Survey of Current business. August. Wash., D.C.

UNITEd States INTERSTATE COMMERCE COMMISSION

1959. Carload waybill analysis, state-to-state distribution of animals and products traffic and revenue, one per cent sample of terminations in the year 1958. Wash., D.C.

Wallace, T. D., and G. G. JUdGE

1958. Econmetric analysis of the beef and pork sectors of the economy. Oklahoma Agr. Exp. Sta. Tech. Bul. T-75.

WEBER, ALFRED

1909. Uber den Standort der Industrien, Tübingen; English translation with introduction and notes by Carl J. Friedrich, Alfred Weber's Theory of the location of industries. Univ. of Chicago Press, Chicago, 1929. 